\title{
A coleção fotográfica de Marcel Gautherot*
}

\author{
Lygia Segala \\ Faculdade de Educação e Programa de \\ Pós-graduação em Antropologia da Universidade \\ Federal Fluminense
}

\author{
* Este artigo faz parte de \\ um projeto mais amplo \\ sobre Marcel Gautherot \\ financiado pelaThe Getty \\ Foundation.
}

RESUMO: Considerando o debate contemporâneo da antropologia sobre a fotografia, interessa compreender a constituição de uma das mais importantes coleções fotográficas sobre o Brasil do século XX, aberta à consulta pública, a do francês Marcel Gautherot (1910 - 1996). São cerca de 25 mil fotogramas, adquiridos em 1999 pelo Instituto Moreira Salles e guardados em sua reserva técnica, no Rio de Janeiro. Comenta-se no texto o trabalho do fotógrafo, vinculado a projetos documentários de instituições como o Musée de l'Homme, em Paris, no final dos anos 1930, e no Brasil, o Serviço de Patrimônio Histórico e Artístico Nacional e a Campanha de Defesa do Folclore Brasileiro, entre os anos 1940-1960. Tais compromissos e interesses definem eixos temáticos importantes na produção e na organização do seu acervo fotográfico pessoal. Procura-se discutir os critérios e os procedimentos técnicos que adota para a realização e a classificação de suas imagens, precisando séries, narrativas visuais sobre a diversidade cultural brasileira. Com a aquisição do seu acervo pelo IMS, ganha mais relevo, enquanto coleção institucional, sua qualidade estética. Redefinem-se modos de preservação e conservação, reprodução e circulação dessas fotografias.

PALAVRAS-CHAVE: Fotografia etnográfica. Coleção fotográfica. Patrimônio cultural. Marcel Gautherot. Brasil.

ABSTRACT: Considering contemporary Anthropology's debate around photography, there is a keen interest in the understanding of one of the most important open to public consultation photographic collections on 20 ${ }^{\text {th }}$ Century Brazil, that of Frenchman Marcel Gautherot 11910 1996). The collection comprises around 25,000 photographs, purchased in 1999 by Instituto Moreira Salles and kept in its fund in the city of Rio de Janeiro. The text comments on the photographer's work, linked to documentary projects under the patronage of institutions such as the Musée de l'Homme in Paris, at the end of the 1930s, and both the National Historic and Artistic Patrimony Service and the Brazilian Folklore Defence Campaign, in Brazil, between the years of 1940-1960. Such commitments and interests define important thematic groupings in the production and organisation of his personal photographic archive. A discussion about 
1. BECKER, 1986, p. 223 271.

2. A propósito, Maresca observa que:"les termes de cette proximité sont indéniablement problématiques. Car l'une des options par lesquelles les sociologies ont cherché à affirmer la scientificité de leur discipline dans le cadre académique a été précisément, de se démarquer de l'image documentaire. Déjà, au tournant du siècle, les anthropologues de terrain avaient affiché dans le mode de construction et d'écriture de leurs monographies spécialisées une rupture avec le récit de voyage traditionnel, qui elle aussi était passé par un rejet de l'imagerie et des descriptions exotisantes". MARESCA, 1996, p. 12 .

3.As discussões recentes sobre a produção etnográfica, como se sabe, colocam em questão a exatidão e a transparência dessas imagens documentais, a crença na capacidade mimética da fotografia. Ver MARESCA, 1996; COLLEYN, 2004; ROUILLÉ, 2005 (especialmente a primeira parte do livro); BELTING, 2004 , p. 77-118.

4. PIETTE, 1996

5. Segundo Sérgio Burgi, responsável pela reserva técnica de fotografia do Instituto Moreira Salles, há, desse total, cerca de 18 mil negativos, $3 \mathrm{mil}$ cromos e cerca de $3 \mathrm{mil}$ imagens em contatos, sem os negativos originais (entrevista realizada em 17/5/2004).

6. É importante lembrar, como assinala Elizabeth Eduards, que "photography aided the reification process as creations of the mind became concrete, observed realities, criteria and technical procedures adopted by the photographer is attempted, detailing series and visual narratives about Brazilian culture's density. With the photographs' purchase by the IMS, the oeuvre's aesthetic quality, now as an institutional collection, is highlighted. The collection's manners of preservation and conservation, reproduction and circulation are redefined.

KEYWORDS: Ethnographic Photography. Photographic Collection. Cultural Heritage. Marcel Gautherot. Brazil.

Experimentos fotográficos e ciências sociais surgem enquanto técnica e campo disciplinar aproximadamente em uma mesma época e comprometemse desde então, como já observou Howard Becker', apesar da diversidade de projetos, com a "exploração da sociedade" 2 . Nos debates contemporâneos da antropologia, a fotografia aparece como uma categoria particular de imagem ou como objeto visual com valor de uso ou de troca em diferentes grupos sociais. Define-se mais largamente no trabalho de campo como modo de observação, registro descritivo ou de autentificação ${ }^{3}$, instrumento para coleta de dados. Desdobra-se, nas sínteses de gabinete, como ilustração etnográfica contraponto do argumento textual ou do exercício interpretativo preocupado com a "focalização do detalhe particular" 4 . Insere-se também, em outras análises, contemplando várias ordens argumentativas e processos particulares de circulação e apropriação, como objeto retórico, peça votiva ou identitária, lembrança, relicário, obra de arte, item de coleção.

Nessas notas, considerando essa dupla dimensão da expressão fotográfica, é interessante compreender a constituição de uma das mais importantes coleções fotográficas sobre o Brasil do século XX, aberta à consulta pública, a do francês Marcel Gautherot (1910-1996). São 25 mil fotogramas, adquiridos em 1999 pelo Instituto Moreira Salles e guardados em sua reserva técnica no Rio de Janeiro5. Entre os anos 1940-1980, Gautherot produz esse extenso trabalho focando, principalmente, o patrimônio cultural material e imaterial do país ${ }^{6}$. Tratarei o assunto a partir das relações construídas por Gautherot com duas instituições públicas, o Serviço de Patrimônio Histórico e Artístico Nacional e a Campanha de Defesa do Folclore Brasileiro, que encomendam seus serviços e apóiam seus deslocamentos no país, nos anos 1940 -1950, principalmente, determinando roteiros fotográficos que interessavam a seus projetos de pesquisa, de preservação e de difusão.

Com formação em arquitetura, como já comentou minha colega Heliana Salgueiro, o fotógrafo busca nas paisagens, nas comemorações e na vida cotidiana, na história vivida das ruas, o equilíbrio minucioso das formas, o jogo com a profundidade de campo e o movimento, o registro calculado das luzes. Previsualiza o momento particular em que as disposições do quadro sintetizam como trama gráfica e representação o acontecimento.

Esse tipo de síntese, porém, segundo Lévi-Strauss", guarda uma plasticidade de contingência a contra-senso da abstração intelectual. Faz sentido na etnografia como foto resíduo - referência de testemunho e nostalgia e como 
foto resgate - uma reserva documental, onde está em foco a preservação, a obrigação moral da memória ${ }^{8}$.

Cabe relembrar que a formação fotográfica de Gautherot tem como primeira referência seus experimentos com a revelação fotográfica no laboratório do novo Musée de l'Homme, em Paris, onde participa, como arquiteto decorador, do projeto de reorganização das exposições etnográficas, sob a direção de Paul Rivet (1937-1938). Em notícia de jorna| ${ }^{10}$ sobre a inauguração do Musée de l'Homme, recortada e guardada por Gautherot, aclama-se este "musée vivant", sem equivalente nos Estados Unidos nem na Alemanha. Na reportagem, frisamse os recursos técnicos da mostra, o mobiliário moderno, a iluminação, os materiais de revestimento, a ordem das vitrines, a sinalização fotográfica, a cenografia de efeitos. A exposição, conceitualmente, pretendia tratar a espécie humana na sua totalidade, percorrendo os continentes explorados a partir de mapas em relevo. A matéria aplaude a equipe do museu, especialmente as artes de Georges-Henri Rivière" ${ }^{11}$ que já se destacara na organização da primeira exposição popular de arte pré-colombiana na França, em 1928. Exalta a colaboração fecunda entre o etnólogo, o arquiteto e o decorador. Marcel Gautherot aparece na lista dos nomes reverenciados.

Cabe notar que o novo Musée de l'Homme, concebido como parte da Exposição Internacional de 1937'12, reunia etnólogos como Alfred Métraux'13, André Leroi-Gourhan ${ }^{14}$, Maurice Leenhardt ${ }^{15}$, Marcel Griaule ${ }^{16}$, Michel Leiris ${ }^{17}$, Jacques Soustelle ${ }^{18}$, freqüentadores dos seminários de Marcel Mauss no Institut d'Ethnologie, da Université de Paris, criado em 1925. Nesse contexto particular de discussão, precisavam-se estratégias metodológicas para o trabalho de campo com implicações nos projetos da museografia, considerada como ramo da etnografia descritiva.

No seu Manuel d'Ethnographie, publicado em 1947, Mauss insiste que "l'ethnographie doit avoir le souci d'être exact, complet; il doit avoir le sens des faits et leurs rapports entre eux, le sens de proportion et des articulations" 19 . Sugere que "le collecteur s'attachera à composer des séries logiques en réunissant si possible tous les échantillons d'un même objet"20. Era importante localizar a produção desses objetos, seu uso social: "on ne fera jamais trop de photos, à condition qu'elles soient toutes commentés et exactement situées: heure, place, distance" ${ }^{\prime 21}$. Tal recomendação extrapola o recurso complementar do registro textual na coleta de dados ou nas exposições. Sublinha o uso da fotografia, enquanto método de observação material, recomendando que a documentação da vida social seja feita sem pose.

Na nova ordem argumentativa do Musée de l'Homme, a preocupação com o rigor documentário marca uma clara diferença com relação ao Musée d'Ethnographie du Trocadéro, que até os anos 1930 conservava e exibia as coleções etnográficas francesas. Neste museu, a justaposição inesperada das peças, na maioria das vezes mal classificadas e sumariamente identificadas, correspondia ao que James Clifford chamou de uma "estética do surrealismo etnográfico" 22 . recorded in the mechanical eye of the camera. Through photography, for example, the 'type'the abstract essence of human variation was perceived to be an observable reality". EDUARDS, 1992, p. 7. Ver também EDUARDS, 1990 , p. 235 258;WRIGHT, 1992, p.1831.

7. Entrevista a Antoine de Gaudemar (Libération), publicada no jornal $\mathrm{Fo}$ lha de $S$. Paulo em 15/1/1995.

8.André Bazin fala da fotografia como uma "entreprise de sauvetage: sauver l' être par l'apparence" (BAZIN, 1987).

9.Paul Rivet (1876-1958), antropólogo francês com trabalhos de pesquisa, nos anos 1920 , em países andinos. Em 1929 tornase professor de Antropologia no Muséum National d'Histoire Naturelle e diretor do Musée d'Ethnographie du Trocadéro, em Paris. Em 1937, reorganiza com George-Henri Rivière as coleções de antropologia física e de etnologia desses museus, no âmbito do novo Musée de 1'Homme, que passa a dirigir. Militante socialista, durante o regime de Vichy, refugia-se na América Latina, criando o Instituto de Etnografia de Bogotá e o Instituto Francés da América Latina, no México. Cabe indicar que, em 1934, ainda no antigo Musée d'Ethnographie du Trocadéro, o fotógrafo Pierre Verger fora admitido como "colaborador voluntário", sendo encarregado do laboratório fotográfico. Seu capital de experiências, acumulado em várias viagens como repórter fotográfico, qualificavam-no diante de antropólogos e etnólogos, pesquisadores do museu. Seus primeiros trabalhos 
foram ampliações de chapas feitas por Alfred Métraux, na Ilha da Páscoa, para a exposição sobre as civilizações no Pacífico, preparada por GeorgeHenri Rivière. Em 1937 fotografa a Exposição Universal, publicando 48 fotos na revista Arts et Métiers Graphiques (VERGER, 1982, p. 95).As primeiras relações entre Verger e Gautherot, estreitadas, como se verá adiante, no Brasil, desenham-se nesse contexto.

10. Le Jour, Paris, 10/5/ 1938. Acervo Instituto Moreira Salles.

11. Sobre o desenvolvimento da estética etnomuseológica de Rivière, ver GORGUS, 2003.

$12 \mathrm{O}$ museu, indica Clifford, era um símbolo dos ideais do Front Populai$r e$. Rivet, socialista, entendia, então, como fundamental a articulação da "ciência com a educação do público na perspectiva de um humanismo progressista". Ver CLIFFORD, 1998, p. 159. Por outro lado, era um projeto que colocava em foco, dentro de um contexto de concorrência internacional, a dominação colonial. Benoît de l'Estoile chama a atenção para a convergência, no período, entre a racionalidade científica do Musée de l’Homme e a racionalidade burocrática e administrativa da Escola Colonial.Ver L'ESTOILE, 2002, p. 61-93.

13.Alfred Métraux (19021963), etnólogo suíço,naturalizado norte-americano. Escreveu inúmeros trabalhos sobre arqueologia, história e etnologia daAmérica do Sul e da Polinésia, destacando-se os estudos sobre cultos afroamericanos e o campesinato haitiano. Para uma síntese de seus trabalhos
Paul Rivet argüiu essa ordem compilatória, o tratamento estético dos $a_{\text {rtefatos }}^{23}$. Tendia a ver a humanidade "sob uma perspectiva evolucionária e difusionista, enfatizando o desenvolvimento biocultural de longa duração e a reconstrução de seqüências históricas através do colecionamento extensivo e da comparação de traços" ${ }^{\prime 24}$. Alargava-se, no novo museu, a concepção estritamente "anatômica" da antropologia física, abrindo-se espaço para os "fatos culturais" 25 . Nas descrições reconstituídas, importavam os registros visuais e a linguagem dos objetos, "lembranças duráveis e precisas" 26 das análises textuais.

No arquivo institucional, acumulavam-se dois grupos significativos de fotografias sobre antropologia física, pré-história e etnologia: as que identificavam os objetos das diferentes coleções do museu e aquelas realizadas nas pesquisas de campo ${ }^{27}$. Destacavam-se entre estas as coleções de Alfred Métraux ${ }^{28}$, Claude Lévi-Strauss ${ }^{29}$ e especialmente a de Marcel Griaule. No seu trabalho, Griaule utilizava a imagem de forma sistemática, definindo, sobretudo a partir da missão Dakar-Diibouti ${ }^{30}$, um verdadeiro "método fotográfico" na pesquisa etnográfica. Explora a multiplicação de pontos de vista, a construção de seqüências narrativas para descrever um acontecimento da forma a mais completa possível ${ }^{31}$. A "observação visual" era tida como fundamental "para provocar, controlar e verificar discursos confessionais" ${ }^{\prime 2}$. No exercício etnográfico, a câmera fotográfica instigava, segundo Griaule, de forma intrusiva, a "verdade". ${ }^{33}$ Tais idéias marcam a produção fotográfica de técnicos e pesquisadores ligados ao museu.

A organização das imagens coletadas articulava-se no arquivo à ordem dos objetos expostos no museu ${ }^{34}$. Era estruturante o critério geográfico, secundarizando-se os registros de autoria, as datas, os contextos particulares de realização ${ }^{35}$. Seguia-se uma classificação temática das imagens, contemplando estudos de morfologia e fisiologia sociais, sublinhados nos sumários das monografias clássicas ${ }^{36}$.

Nas exposições, a fotografia era utilizada como título visual (imagem de síntese de segmentos da mostra), como contextualização ou substituição de objetos que pela sua dimensão ou importância não podiam ser trazidos para o museu $^{37}$. As imagens escolhidas estabilizavam objetivações concorrentes e sucessivas da vida social. A crença na máxima evidência fotográfica, nesse contexto, define uma conexão mais imediata, entre o visível - as fotografias - e o invisível - a totalidade de uma cultura específica ${ }^{38}$, produzindo valores testemunhais, patrimoniais ou emblemáticos.

Provocado pelo debate dos cientistas e dos técnicos do museu sobre os modos de representação do outro, as relações entre observação, colecionismo e conhecimento, arte e etnografia, Marcel Gautherot decide lançar-se, nos limites de sua especialidade técnica, sur le terrain. Com o apoio de Jacques Soustelle e de George-Henri Rivière ${ }^{39}$, realiza alguns ensaios fotográficos no México, em 1936. Cabe indicar que, nesse mesmo ano, Pierre Verger fotografa no mesmo país, publicando seu trabalho no livro Méxique, editado por Paul Hartmann, em 1938. A introdução e as notas do livro são de Jacques Soustelle que então colaborava com os etnólogos mexicanos para a criação da Sociedade Mexicana de Antropologia, na Cidade do México. $O$ trabalho de Gautherot foi também 
publicado e reconhecido em revistas francesas, como comentou Heliana Salgueiro, estimulando-o a redefinir interesses e projetos.

A fotografia - para Gautherot ${ }^{40}$ - surge do seu desejo de mobilidade, de ruptura ${ }^{41}$; "une espèce de réparation de soi par l'action et le mouvement" ${ }^{\prime \prime}$. É da viagem que ele constrói o sentido novo do seu ofício, a especificidade de sua identidade profissional como fotógrafo.

Em 1939, visita o Brasil. Preocupava-se o fotógrafo em explorar a luz dos trópicos, os "aspectos tanto paisagísticos como humanos da região a fim de enviá-los para a coleção do Museu"43. Define sua atividade como exercício de "fotojornalismo científico" 44 , pela atenção que dá aos detalhes da vida social observada, às instruções da pesquisa etnográfica. Paul Rivet the dá carta de recomendação às autoridades francesas no Brasil e na América do Sul, atestando os interesses do museu nesse ensaio fotográfico ${ }^{45}$. Com a guerra, porém, interrompe suas primeiras incursões documentárias na Amazônia ${ }^{46}$, voltando ao Brasil depois do primeiro armistício.

Diferentemente de Pierre Verger, que tinha sempre "le pied à l'étrier", correndo o mundo (como dizia Alfred Métraux) ${ }^{47}$, Gautherot embrenha-se dentro das fronteiras do país. É como viajante que se percebe e se apresenta, definindo um "olhar nômade" sobre o Brasil. Essa proximidade distante, dos que vêm de fora, como sublinha Simme|${ }^{48}$, engendra formas particulares de observação, de mediação, de interação social ${ }^{49}$. A idéia de viagem, nos seus comentários, trança-se, de início à de fuga do espaço doméstico, da família francesa, da pobreza e dos impasses políticos na Europa ${ }^{50}$. Os interiores do Brasil, muito especialmente a região do Rio São Francisco, no Nordeste, têm especial relevância na qualificação de sua experiência de mobilidade como estratégia de enraizamento simbólico para dentro e para longe. Seguindo a recomendação de Michel Leiris, que conhecia do Musée de l'Homme, interessa-se a "voyager 'non en touristes (ce qui est voyager sans coeur, sans yeux et sans oreilles) mais en ethnographes, de manière à devenir assez largement humains pour oublier leurs médiocres petites manières de blanc'"151.

Seus trajetos pelo país, com tempos e extensões particulares, paradas negociadas, fazem-se em função de encomendas recebidas, de serviços fotográficos arranjados durante percursos de viagem ou ainda de projetos pessoais do fotógrafo, desenvolvidos por conta própria.

No Rio de Janeiro, onde tem seu endereço ${ }^{52}$, conhece Rodrigo Mello Franco de Andrade, diretor do Serviço do Patrimônio Histórico e Artístico Nacional (SPHAN), recém-criado em 1937, no âmbito do processo de centralização autoritária do governo Vargas ${ }^{53}$. $\bigcirc$ serviço, ligado ao Ministério da Educação e da Saúde, tinha por objetivo preservar e restaurar bens culturais representativos para a história oficial ${ }^{54}$. Nos seus quadros, os intelectuais de relevo, vinculados ao movimento modernista, tinham sua atuação pautada pelas tensões de um duplo compromisso. De um lado, com um projeto cultural renovador, interessado nas novas linguagens estéticas, na construção orientada da tradição brasileira. De outro, com as exigências de um governo autoritário, com as prescrições do Estado Novo (1937-1945) ${ }^{55}$. A posição de Gustavo Capanema no ministério ver MÉTRAUX,1964, p. 603-609.

14.André Leroi-Gourhan (1911-1986), etnólogo francês. Deixou várias contribuiç̃oes no âmbito da antropologia física (a hominização), da etnologia (tecnologia e estética) e da pré-história (métodos de escavação, arte rupestre, estrutura do habitat, evolução das sociedades). Em 1945, torna-se subdiretor do Musée de 1'Homme onde funda o Centro de Formação para a pesquisa etnológica. Sobre sua trajetória profissional ver BONTEIZAR, 1991, p. 414-416.

15 Maurice Leenhardt (1878-1954), teólogo, missionário da Sociedade das Missões Evangélicas de Paris, trabalha na Nova Caledônia de 1902 a 1926. Dedica-se depois aos estudos de etnologia e etnolingüística em Paris, sucedendo Marcel Mauss, em 1941, na École Pratique des Hautes Études, na cátedra de religiões de povos não civilizados. É então, também responsável pelo Departamento de Oceania do Musée de 1’Homme. Para uma revisão dos seus trabalhos ver CLIFFORD, 1998, p. 227-251.

16. Marcel Griaule (18981956), etnólogo francês, realiza suas primeiras pesquisas na Abissínia (1928). Destaca-se na Missão Dakar-Djibouti (1931-33), vinculada ao Museu de Etnografia do Trocadéro, desenvolvendo a partir de então extenso trabalho sobre os dogons do Sudão francês, atual Mali. Em 1943,é nomeado professor na Sorbonne, como titular da primeira cátedra de etnologia geral. Para uma discussão de suas referências teóricas e de sua metodologia de trabalho ver 
CLIFFORD, op. cit., p. 179-226.

17. Michel Leiris (19011990), escritor e etnólogo francês, participa do movimento surrealista nos anos 1920 e mais tarde, com Marcel Griaule, da Missão Dakar-Djibou-

ti. Colabora ativamente na reformulação do Musée de 1'Homme em 1937. Ligado ao Centre National des Recherches Scientifiques, realiza pesquisas etnográficas na África subsaariana

(1945) e nas Antilhas francesas (1948 e 1952). Ver PRICE; JAMIN, 1988, p. 29-56.

18. Jacques Soustelle (1912-1990), etnólogo francês. Entre 1932 e 1940 encarregou-se de várias missões científicas no México especializando-se no estudo de civilizações pré-colombianas.

19. MAUSS, 1967 , p. 7.

20. Id., p. 17. No mesmo texto, o autor observa que: "Pour être precise, une observation doit être complète. [...] Il s'agit de reproduire la vie indigène, non pas de procéder par des impressions; de faire des séries, et non des panoplies", p. 21

21. Ibid. p. 21.

22. A esse respeito ver CLIFFORD, op.cit..Como observa o autor, o surrealismo partilhava essa situação irônica com a etnografia relativista do período entre guerras,"alterando, diante de alternativas exóticas, hierarquias de valor do real" (p. 148). O autor argumenta que a etnografia nesse pe ríodo estava referida a uma predisposição cultural mais geral, que atravessa a antropologia moderna e que esta ciência partilha com a arte a escrita do século XX (p. garantia-lhes, porém, nos limites dos jogos de poder, uma expressiva autonomia na produção de valores e significados novos para uma "política do passado". Tomava corpo, segundo Sérgio Miceli, "a concepção de 'cultura brasileira' sob cuja chancela, desde então, se constituiu uma rede de instâncias de produção, distribuição e consagração de bens simbólicos, às custas das dotações oficiais" 56 .

Orquiteto Lucio Costa lembra-se de Gautherot "o mais artístico" dos fotógrafos do patrimônio chegando ao SPHAN, irrompendo "repartição a dentro sobraçando uma pasta com belas fotos da Acrópole, na companhia de Pierre Verger" ${ }^{\prime \prime 7}$. Rodrigo Mello Franco de Andrade entusiasmou-se com o material, acolhendo Gautherot como um de seus colaboradores, assegurando-lhe trabalhos comissionados. Por seu intermédio, Gautherot freqüenta intelectuais modernistas da cidade como Carlos Drummond de Andrade, o próprio Lucio Costa, Alcides Rocha Miranda e Mário de Andrade. Foi Mário de Andrade, segundo Turazzi ${ }^{58}$, que instaurou no SPHAN

o que poderíamos chamar de "uma política de documentação fotográfica" das manifestações culturais, históricas e artísticas, populares e eruditas, edificadas e não edificadas que constituíam a identidade do Brasil e, por conseguinte, formariam através da iconografia uma visão do seu patrimônio ${ }^{59}$.

Em cartas a Rodrigo Mello Franco ${ }^{60}$ (1936-1945), Mário de Andrade ${ }^{61}$ sublinha, por diversas vezes, a importância da fotografia como documentação comprovante nos processos de inventário e nas recomendações de tombamento e restauração das "obras de arte patrimonial". Indica a necessidade de a instituição contar com um "serviço intensivo de fotografação", um trabalho profissional bem instruído ${ }^{62}$ que precisasse informações para estudos comparativos "na reconstituição de monumentos da nação". Insiste na idéia de um acervo cumulativo - "um arquivo central único de negativos" 63 - que objetivasse, por operações seletivas e de transcrição, o repertório valorado de bens culturais do país.

Cabe notar que a atenção de Mário de Andrade à documentação fotográfica afirmara-se desde suas viagens etnográficas (1 927-1929), como bem mostrou a professora Telê Ancona Lopez, estendendo-se às discussões da Sociedade de Etnografia e Folclore (1936-1939), ligada ao Departamento de Cultura da Prefeitura de São Paulo, sob a sua direção (1935 -1938). Tal empenho se objetivou ainda no representativo trabalho fotográfico realizado pela Missão de Pesquisas Folclóricas, que organizara em $1938^{64}$.

No SPHAN, era o Brasil do barroco, da arquitetura e da imaginária religiosa que interessava especialmente preservar dos escombros e da ruína. Percebia-se o barroco, frisa Marisa Veloso, "como a primeira manifestação cultural tipicamente brasileira, possuidor portanto da aura da origem da cultura brasileira, ou seja, da nação"65. As idéias de autenticidade e excepcionalidade balizavam os procedimentos de escolha, de tombamento. Sugeriam a produção de "continuidade, totalidade e essência", evocando, como sugere Thiesse ${ }^{66}$, 
uma comunidade atemporal, marca identitária, cuja legitimidade residiria na preservação de uma herança comum.

Gautherot fotografa para o SPHAN santuários mineiros, fazendas e casas coloniais das cidades. Articula a expectativa dos "inventários do mundo visível", apregoada desde meados do século XIX, à "utilidade prática" de um projeto oficial, vinculando circunstancialmente o ver e o dever.

Em função dos usos específicos da fotografia na instituição, como documentação elucidativa, as encomendas de serviços eram pormenorizadas, os enquadramentos estipulados ${ }^{67}$. A preocupação complementar em distinguir $e$ solenizar monumentos definia instruções para a construção de pontos de vista à vocação emblemática ${ }^{68}$. Essas fotografias eram reproduzidas, quando de interesse, em publicações ${ }^{69}$ e exposições.

Gautherot, para além das prescrições dos encomendantes, marca uma especificidade autoral por sua composição calculada no detalhe, a contrapelo do instantâneo fotográfico. Como bem observa Ana Luiza Nobre,

pouco ou nada em suas fotografias de arquitetura parece produto do impulso, do acaso ou da surpresa, mas antes de um princípio formal, uma intenção compositiva resolvida com rigor matemático e sujeita à ponderação de uma série de fatores, nos quais a incidência da luz, a distância focal, a posição, altura e distância do observador somam tanto quanto a forma, o volume, as coordenadas de cada um dos elementos enquadrados, sejam eles as sombras, as linhas horizontais e as verticais, todos os elementos, enfim, são simultaneamente mobilizados e regulados em favor da estruturação de um real impalpável que a sensibilização da película, naquele momento exato e irrepetível, consubstancia e torna definitivo. Obcecado pelo pormenor, Gautherot exige de cada um desses componentes rendimento máximo na trama de relações espaciais que institui ${ }^{70}$.

As encomendas feitas por Rodrigo Mello Franco definiam estruturalmente, nos anos 1940 -1950, a direção dos seus deslocamentos, apresentando-the a instituições e pessoas de referência que organizavam ou apoiavam seus serviços e que, por sua vez, abriam contatos para percursos e visitas mais distantes. A construção dessas redes de relações permitia outros acertos locais de trabalho com órgãos da administração pública, com empresas diversas. Essas negociações conformam no seu arquivo séries fotográficas particulares.

É importante sublinhar que o alinhamento institucional para a realização da documentação fotográfica não era, naqueles anos, uma questão residual. Lévi-Strauss, nos Tristes trópicos, relata problemas que teve quando retratou crianças de rua na Bahia, sendo interpelado por inspetores da polícia e chamado a esclarecer seus intuitos ${ }^{71}$. Reclama ainda das agências de controle do Estado, como o Conselho de Expedições Artísticas e Científicas, que suspeitavam de sua viagem de estudos como ameaça ao patrimônio nacional.

Nesses anos 1940, Gautherot viaja pelo país, produzindo, além dos registros sobre a arquitetura colonial e moderna, um repertório de imagens definido então, na geografia humana, como "tipos e aspectos" do país ${ }^{72}$, em que as configurações sociais associam-se à paisagem e os espaços se redefinem como marcadores culturais ${ }^{73}$ (Figura 1). Destacam-se nessas compilações, dos "quadros
136). Relativizando o argumento de Clifford, Nina Gorgus (op. cit. p. 43.) chama a atenção para as "afinidades eletivas" entre o movimento surrealista e o trabalho dos etnólogos do Museu de Etnografia: "affinités életives, dans la mesure où il s'agit dans les deux cas de mouvements qui ont développé, chacun dans leur domaine, des stratégies non conventionnelles pour imposer leurs objectifs et qui ont rompu avec les anciennes traditions. Affinités életives, parce que quelques surrealistes commençaient malgré tout à s'intéresser à l'ethnologie". O fotógrafo Pierre Verger (1982. p. 25) refere-se da seguinte forma a essas relações: "gravitava em volta do museu dirigido por Paul Rivet e George-Henri Rivière uma simpática equipe composta de antigos membros das expedições Dakar-Djibouti, de Marcel Griaule, e para a Groenlândia,de Paul-Emile Victor. Foi a época em que se acotovelavam nos corredores do velho museu do Trocadero,André Schafner com uma partitura de Debussy debaixo do braço; Germaine Dieterlen, transportando com êxtase um objeto dogon; Michel Leiris, elaborando algum manifesto surrealista; Jacques Faublée, que passava freqüentemente suas noites em uma sala do museu, enrolado em um tapete berbere tomado emprestado de uma vitrine; Denise Paulme, Helène Gordon que se tornou Lazareff em seguida; Gessain, entre duas viagens à Groenlândia; Alfred Métraux, na iminência de partir para Honolulu..."

23. CLIFFORD, op. cit., p. 137.

24. Id., p. 159-160. 
25. DIAS, 1991, p. 251.

26. RIVET, apud DIAS, op. cit., p. 251.

27. Nos anos 1940 são incorporadas à instituição as coleções fotográficas do século XIX do Laboratoire d'Anthropologie do Muséum National d'Histoire Naturelle. Ver BARTHE; PIERRE, 1999, p. 107-111.

28. Métraux produziu uma das mais importantes coleções fotográficas do Musée de 1’Homme, sobre o Chaco, Ilha da Páscoa e Haiti, mantendo com o fotógrafo Pierre Verger intensa correspondência. Ver MÉTRAUX;VERGER, 1994

29. Reúne fotos realizadas durante suas pesquisas no Brasil sobre os bororo, guarani, kaingang e kadiweu. Algumas delas foram publicadas em LÉVI -STRAUSS, 1955.

30. Michel Leiris (1934) informa sobre a produção detalhada de alguns desses clichês fotográfi$\cos$

31. BARTHE; PIERRE, op. cit., p. 109.

32. CLIFFORD, op. cit., p. 195.

33. Para Clifford (1998, p. 207), aqui "fica-se tentado a falar de uma 'ethnographie vérité' análoga ao 'cinéma vérité' pioneiramente defendido por Jean Rouch, posteriormente associado a Griaule: não uma realidade objetivamente registrada pela câmera, mas provocada por sua presença ativa".

34. Pelo plano estabelecido por Georges-Henri Rivière, "les salles accessibles au public devaient suivre un classement d'abord géographique, puis par tribus, et enfin humanos" - metonímias etnográficas ${ }^{74}$ - , exclusivamente cenas exemplares do trabalho, como mostrou Heliana Salgueiro. O fotógrafo alarga esse recorte já consagrado que essencializa grupos sociais, incluindo figurações novas, tipos de rua, artes e festas populares, devocionais e profanas (Figuras 2 e 3).

Uma seleção dessas imagens é publicada, em 1950, por Paul Hartman em Paris, no livro Brésil $P^{5}$, do qual também participam como fotógrafos Antoine Bon e Pierre Verger ${ }^{76}$. O texto, com introdução de Alceu Amoroso Lima - membro da Academia Brasileira de Letras, líder intelectual católico -, sublinha, das diferenças locais, o sentido de uma unidade nacional, distinguindo o país diante do "desmembramento" colonial espanhol na América. Por esse argumento, as diversidades explicam-se como estágios culturais, territorialmente circunscritos e estreitamente imbricados por uma lógica evolucionista que acompanha a economia e a política das frentes de expansão. Em uma apresentação esquemática em que hierarquiza "gêneros de civilização", as fotografias 1217 imagens) deixam ver e prever, no entusiasmo do autor, o país que se transforma como totalidade e se moderniza ${ }^{77}$.

Já anunciadas no livro, as séries sobre o folclore ${ }^{78}$ têm uma importância particular na produção fotográfica de Gautherot, destacando-se no pavilhão brasileiro da Exposição Internacional de Bruxelas de 1958. Entre centenas de negativos, o fotógrafo distingue, pela exaustividade e apuro técnico, duas séries

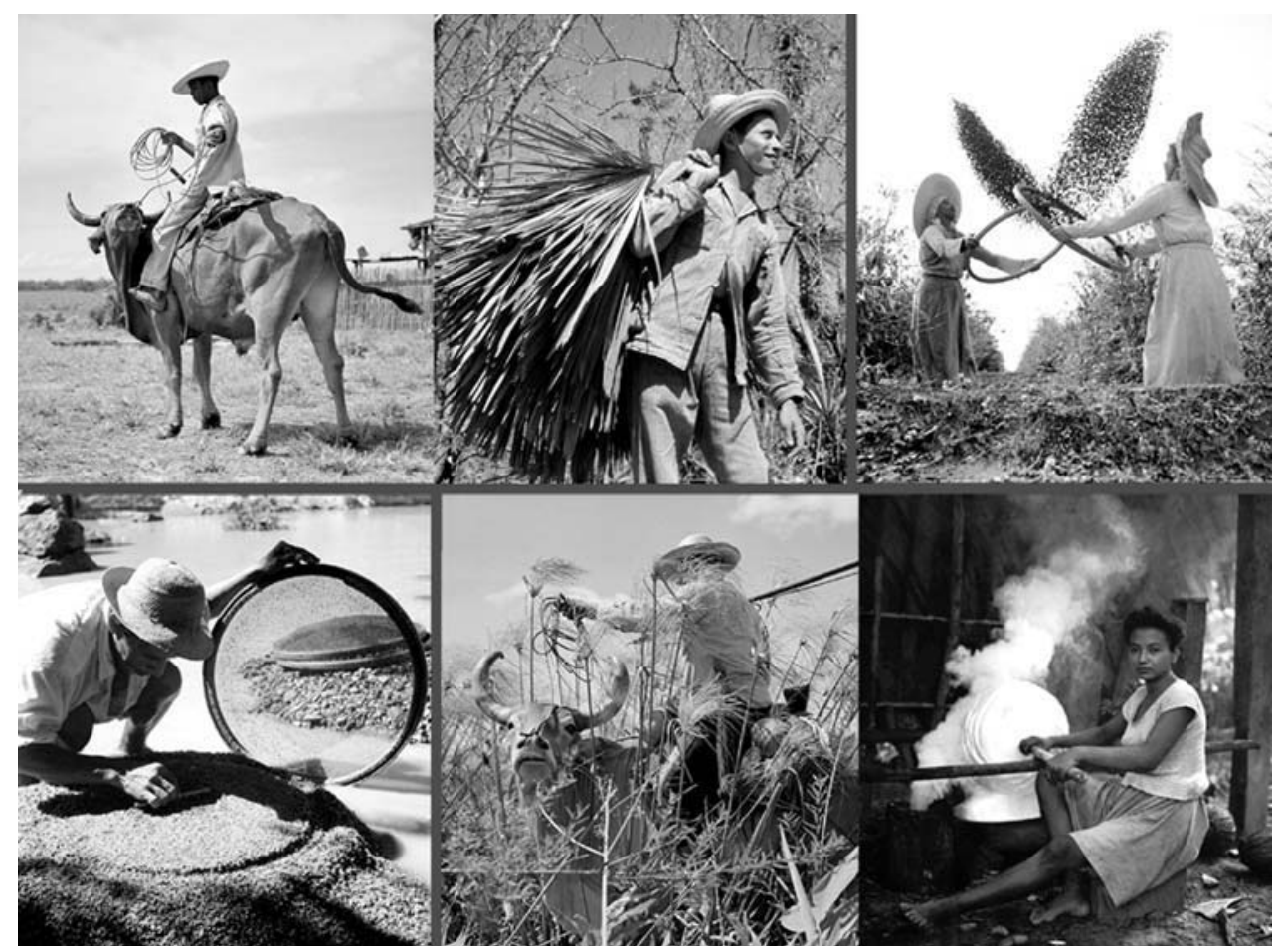

Figura 1 - Vaqueiro, Iha Mexiana/PA, c. 1943. Colheita de carnaúba, Messejana/CE, 19501952. Limpeza de café, Itaquera, São Paulo/SP, c. 1943-1948. Garimpeiro, Tocantins/PA, c. 1944-1948. Vaqueiro, Itha Mexiana/PA, c. 1943. Processamento de látex, Itha de Marajó/PA, c. 1967-1970. Fotografias de Marcel Gautherot. Acervo do Instituto Moreira Salles. 


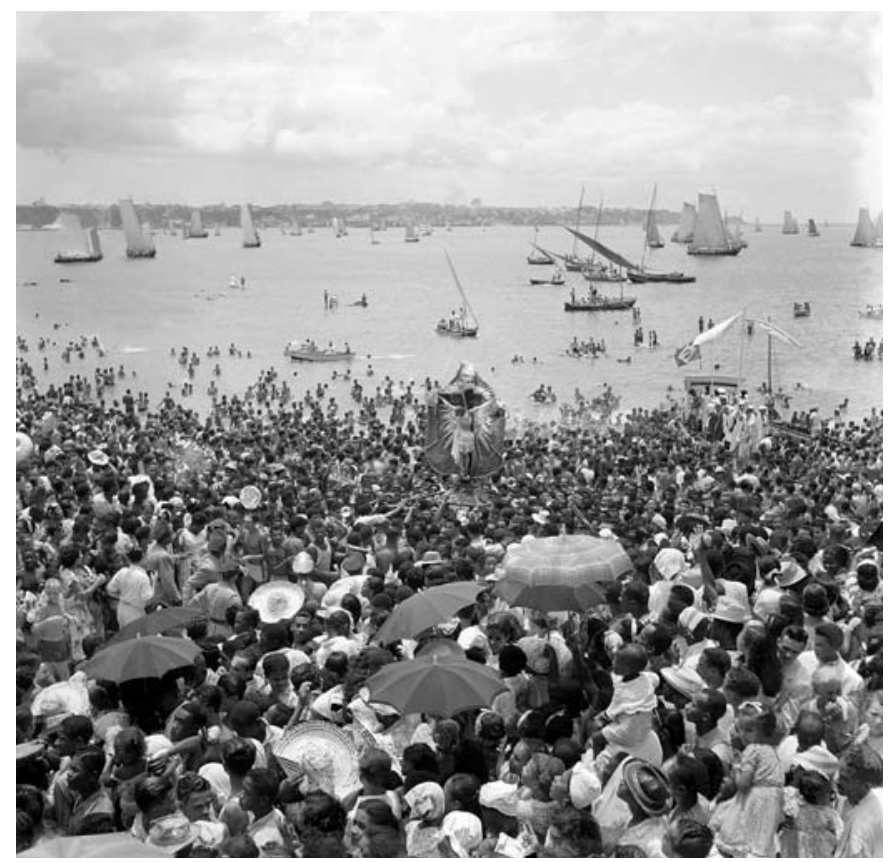

Figura 2 - Procissão de Nosso Senhor dos Navegantes, Salvador/BA, c. 1940-1945. Fotografia de Marcel Gautherot. Acervo Instituto do Moreira Salles.

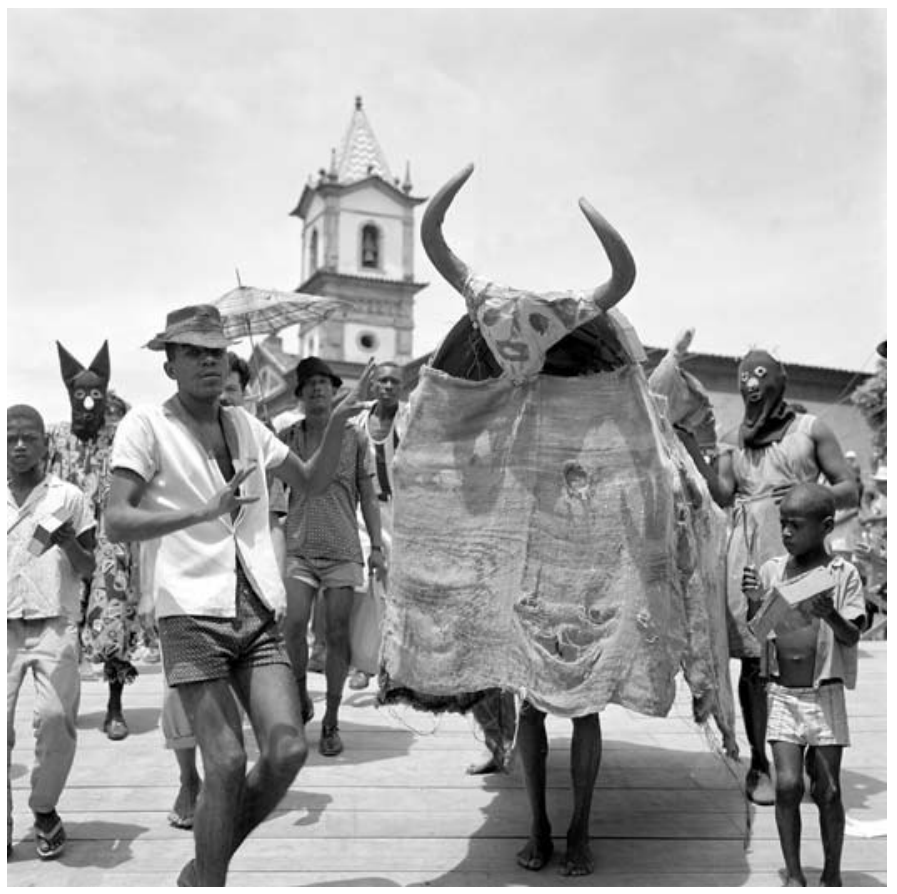

Figura 3 - Carnaval, Salvador/BA, c. 1965-67. Fotografia de Marcel Gautherot. Acervo do Instituto Moreira Salles. par matériel ". GORGUS, op. cit., p. 53.

35. Christine Barthe (2000, p. 71-90) observa que: "cette primauté du contexte géographique a contribué à exclure les conditions de production des photographies. L'identification de la photographie au lieu où elle a été prise semble parfois témoigner du désir d'insérer la scène représenté dans un scénario de l'origine. [...] Le rangement physique des documents accentue cet effet simplificateur puisque toutes les images concernant un même pays étaient regroupées sans distinction de date: la juxtaposition immédiate de photographies du XIXe et du XXe siècle contribuait à abolir toute notion de temps".

36.Ver ODDON,Y."Cadre de classement pour la phototèque d'un Musée d'ethnographie ", apud BARTHE, op.cit., p. 73.

37. No acervo do Instituto Moreira Salles, há uma fotografia de um dos painéis da exposição, vinculado à antropologia física (tâche pigmentaire congénitale), feita por Gautherot. São conhecidas ainda, do período, outras poucas fotografias suas de exposição como a da entrada da mostra Casa Rural Francesa e as do Pavilhão da Espanha, na Exposição de 1937 , mencionadas por Heliana Salgueiro. Os arquivos do Musée de 1’Homme estão no momento fechados à consulta o que dificulta o levantamento de dados sobre o trabalho de Gautherot na instituição.

38. Sobre a discussão dos objetos de coleção como intermediários entre aqueles que os olham e o mundo que representam 
ver POMIAN, 1987, p. 15 $60 ; 1993$, n. 6. p. 1381 1401; 1984. p. 51-86.

39.Archives du Musée de l'Homme, Paris. Correspondance. Lettre de Jacques Soustelle à Marcel Gautherot (22/4/1936); Lettre de Marcel Gautherot à George-Henri Rivière (14/11/1936). Agradeco essas indicações e as da nota 45 a Patricia Peralta.

40. "A fotografia surge antes de tudo do meu desejo de viajar" afirma Gautherot em entrevista que me concedeu, no Rio de Janeiro, em 7/12/1989, a propósito do projeto de reorganização dos arquivos fotográficos do então Instituto Nacional de Folclore (Funarte), sob minha responsabilidade. Os trechos de depoimentos citados, sem outras referências, são desse mesmo documento.

41. "Minha vida é viajar [...], é meu trabalho, minha profissão. Eu tive uma família muito pobre. Eu não gostava de ficar na família, fugia. Aprendi a viajar, a fugir" afirma em entrevista (ver nota acima) Marcel Gautherot.

42. COGEZ, 2004, p. 30

43. "No Recife, o fotógrafo do Serviço do Patrimônio Histórico e Artístico", notícia de jornal sem re ferência de título. Recife [1947]. Documentação particular do fotógrafo. Acervo Instituto Moreira Salles (IMS).

44. A Folba, Belém, 21/6/1939.

45.Archives du Musée de l'Homme, Paris. Correspondance. Marcel Gautherot. Lettre de Paul Rivet $(20 / 4 / 1939)$

46. Lélia Coelho Frota, na Introdução do álbum $\mathrm{Ba}$ -

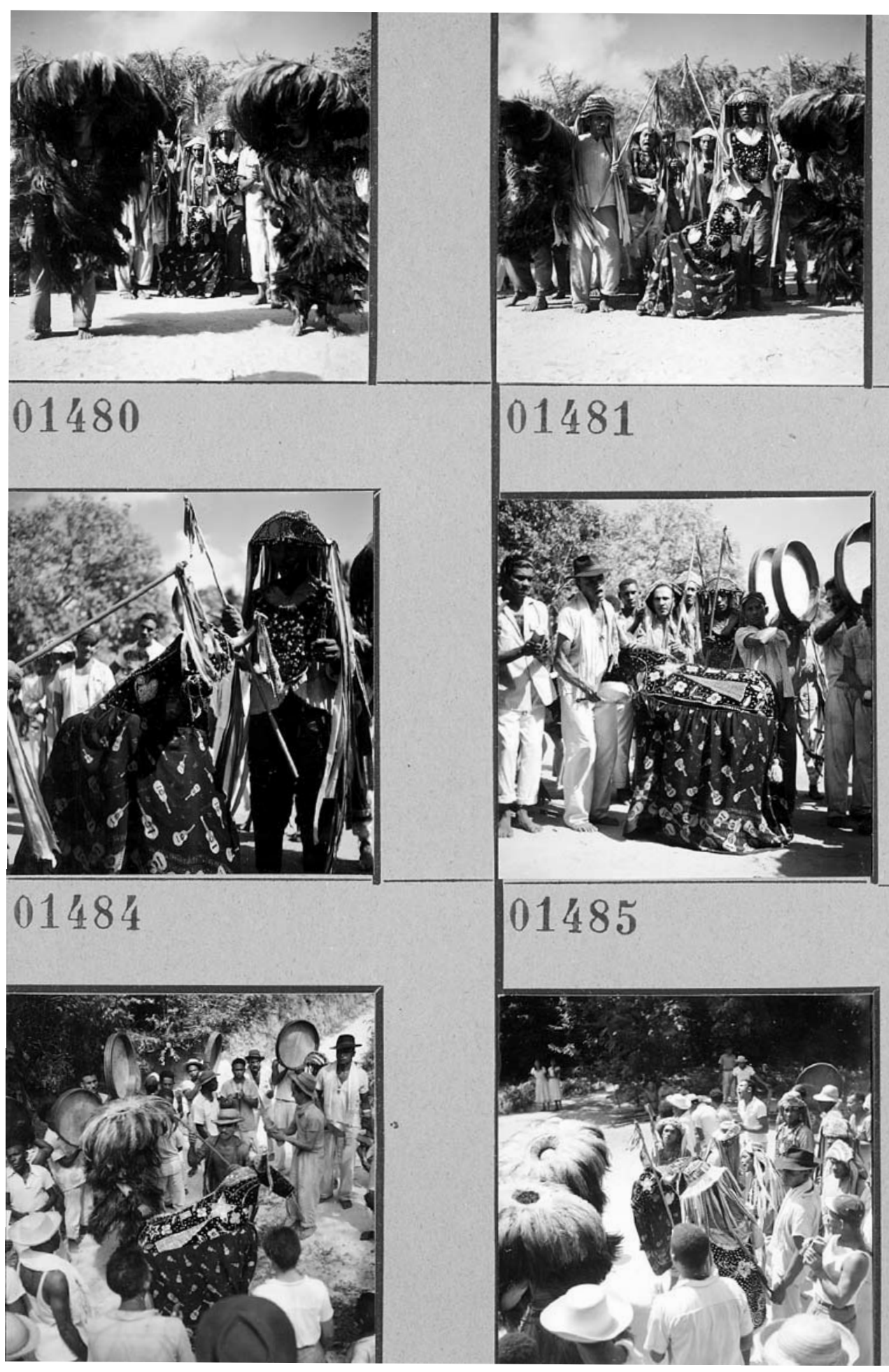

Figura 4 - Bumba-meu-boi, São Luiz/MA, c. 1948-1950. Fotografias de Marcel Gautherot. Acervo do Instituto Moreira Salles. 


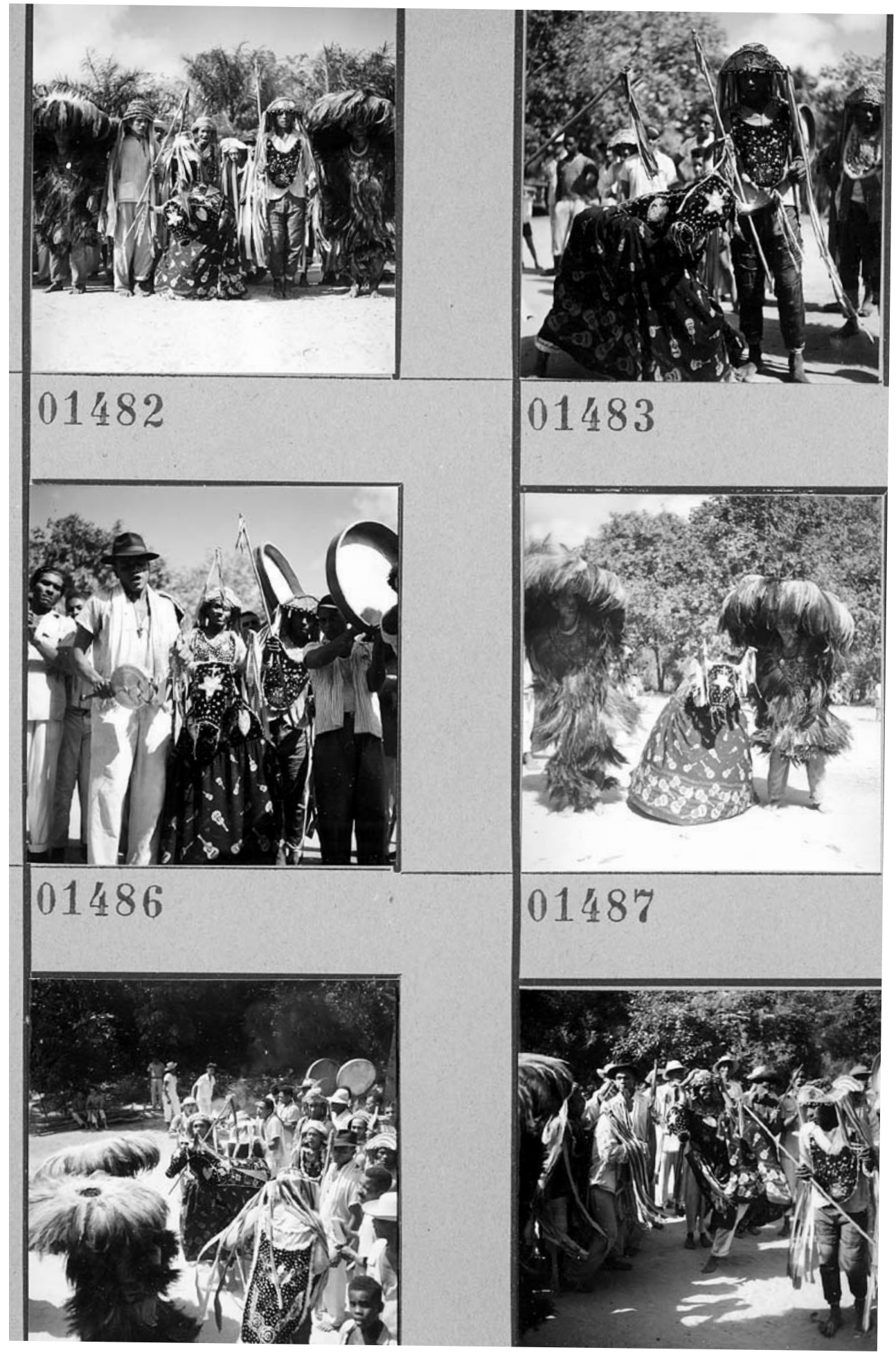

bia, Rio São Francisco, Recôncavo e Salvador: fotografias de Marcel Gautherot (Nova Fronteira, 1995), registra que o fotógrafo viaja "em um vapor rumo à boca do rio Paru, afluente do Amazonas, com o engenheiro Augusto Numa Pinto, do Departamento Nacional de Produção Vegetal e o prefeito de Almerin, Pedro do Carmo Ramos". Realiza, com sua Rolleyflex, um trabalho intensivo de documentação das paisagens locais.

47. METRAUX;VERGER, 1994

48. SIMMEL, 1983, p. 182 184.

49. Nas fotografias, Gautherot expressa essa tensão, trabalhando meticulosamente seu objeto para descobri-lo, depurá-lo da situação de co-presença, perseguindo uma invisibilidade. Volto a esse ponto adiante.

50. Sobre a trajetória social de Gautherot ver SEGALA, 2001, p. 27-57.

51. Apud COGEZ,op.cit., p. 118.

52. Em entrevista dada a Lélia Coelho Frota, em 1995, o artista plástico Carybé conta ter conhecido Gautherot no Rio, nos anos 1940, morando em Copacabana. Ele e Verger foram seus hóspedes por um tempo. Freqüentavam um grupo de amigos formado por Newton Freitas, a historiadora Lydia Besouchet, o escritor e poeta Manuel Bandeira. Cf. FROTA 1995, p. 11.

53. Apreciações sobre esse contexto do nacionalismo como política de Estado, nos anos 19301940, estão no texto de Heliana Salgueiro. 
54. Como observa Cecília Londres Fonseca (2005, p. 23), as políticas de preservação eram "conduzidas por intelectuais de perfil tradicional que se [propunham] a atuar no Estado em nome do interesse público, na defesa da cultura, identificada com os valores das camadas cultas.Ao protegerem a cultura desses grupos, convertida em valor universal, não teriam dificuldades em conciliar, sem maiores conflitos, sua identidade de intelectuais e de homens públicos. No caso do Brasil, essa foi a situação dos intelectuais modernistas que participaram do SPHAN, desde 1937 , e que instauraram uma política cuja continuidade e prestígio se mantiveram durante mais de trinta anos. Entre tanto, diferentemente do que ocorria então na Europa, esses intelectuais eram figuras que, nos seus respectivos campos de atuação, tinham posições de vanguarda, o que conferiu a sua atuação na área do patrimônio uma autoridade diferenciada".

55. Id., p. 82.

56. MICELI, 2001, p. 216.

57.COSTA, 1986, p. 9

58.TURAZZI, 1998, p. 14.

59. Participaram desse empreendimento fotógrafos como o húngaro KazysVozylius e o alemão Erich Hess, Benício Dias, Edgar Jacinto (no Rio de Janeiro) e Germano Graeser (em São Paulo).A produção publicada desses fotógrafos, em revistas e álbuns especializados sobre patrimônio cultural brasileiro, nas conexões específicas com o trabalho de Gautherot,será objeto de estudo futuro.

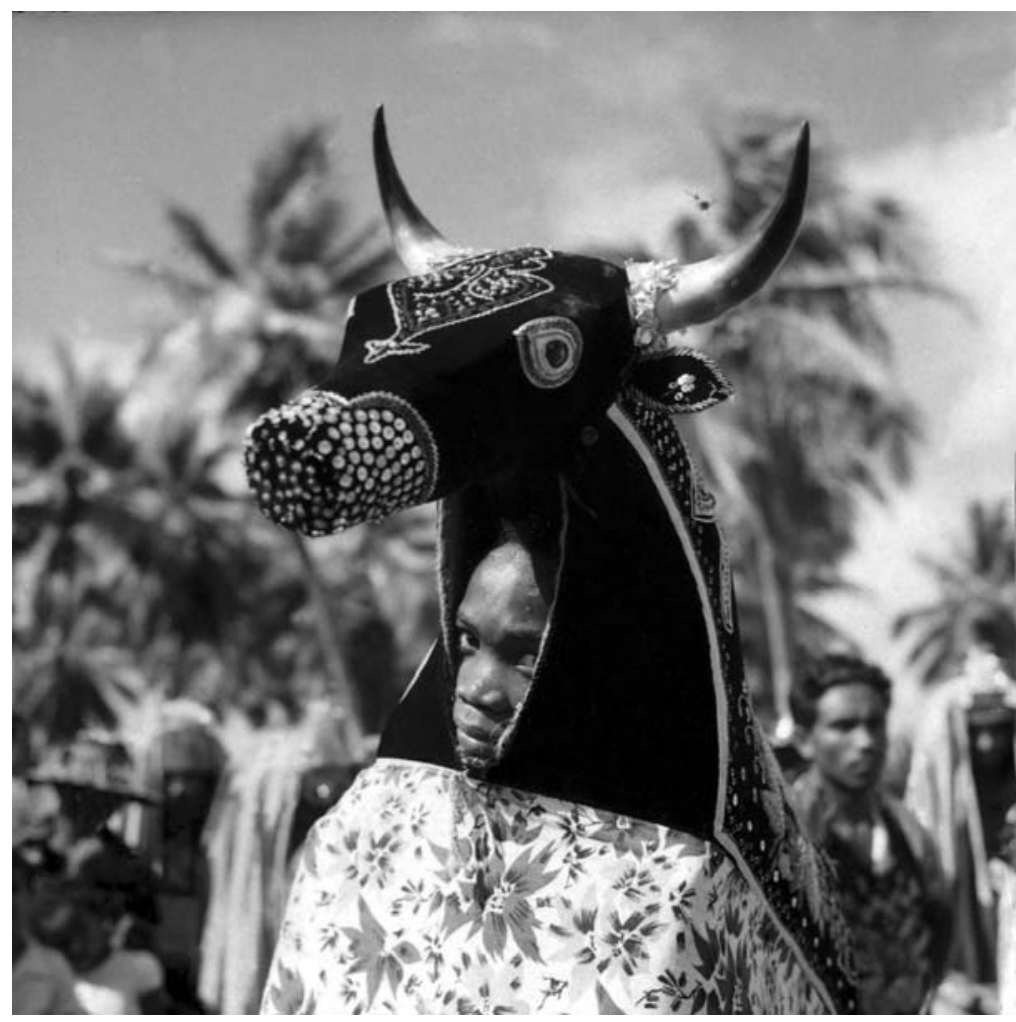

Figura 5 - Bumba-meu-boi, Curupuru/MA, c. 1948-1950. Fotografia de Marcel Gautherot. Acervo do Instituto Moreira Salles.

emblemáticas: a do bumba-meu-boi no Maranhão e a do Reisado e Guerreiros em Alagoas, ambas no Nordeste do Brasil. Nas primeiras imagens mostradas sobre o bumba (Figuras 4 e 5), a composição e o sentido dos planos e a profundidade de campo trazem o lugar e a história para o foco. A representação faz-se em torno de um enredo central que narra a morte e a ressurreição do boi ou o seu extravio criminoso em que se intercalam, satirizando relações de prestígio e de poder, cantos, danças e recitativos cômicos ${ }^{79}$. No Reisado e nos Guerreiros de Alagoas (Figuras 6-8), explora-se a tradição portuguesa das janeiras, festas do ciclo natalino.

Como já indiquei ${ }^{80}$, Gautherot trabalha na fronteira entre a resposta estética que absolutiza a cena e as especificidades dos lugares, das expressões e das interações sociais temporalizadas. Nesses ensaios, ele revela a "autenticidade" naquilo que observa, tramando a sua invisibilidade, o seu passarse despercebido. Na sua perspectiva, a idéia de autenticidade, como singularidade e permanência, liga-se à crença na nitidez documentária, na fidelidade da observação e da fixação do acontecimento, evitando-se nele intervir por recursos da técnica fotográfica, recriando o sentido dos fatos. Nessa distância calculada, fugindo das poses armadas pelos participantes, diz Gautherot querer perseguir o registro objetivo que emociona (Figura 9). 
Na produção dessas séries documentarias, o fotógrafo aproxima-se das perspectivas que animavam os estudos de folclore no país. No debate dos folcloristas, os folguedos populares (danças, desfiles, autos e jogos), conservados pela tradição oral e realizados como empreendimento coletivo, eram então privilegiados para a observação e a identificação dos processos de formação da "cultura brasileira". Representavam para o movimento folclórico que então se articula, seu "próprio objeto em ação" 81 .

movimento folclórico se formaliza, no bojo de políticas nacionalistas populistas, com a criação da Comissão Nacional de Folclore, em fins de 1947. Seu diretor, Renato Almeida, folclorista e musicólogo, funcionário do Ministério das Relações Exteriores, consegue reunir estudiosos de todo o país, centralizando redes de comissões nos Estados e municípios. Vinculado ao debate internacional capitaneado pela Unesco, define um programa centrado na pesquisa mais qualificada e na proteção do folclore. Interessa como medida de preservação, o aproveitamento do folclore na educação, de maneira a consolidá-lo diante das mudanças sociais e culturais geradas então pela industrialização, a urbanização crescente e as migrações internas. Na década de 1950, o movimento chega ao seu paroxismo, desdobrando-se, como ação comum e urgente, na Campanha de Defesa do Folclore Brasileiro (1958). Sob a direção de Edison Carneiro (1961-1964), cria-se a Revista Brasileira de Folclore, patrocinam-se cursos em alguns estabelecimentos de ensino superior e inicia-se a composição de documentários fonográficos e fotográficos ${ }^{82}$.

É por meio de Edison Carneiro, sociólogo e folclorista, de quem se torna amigo e compadre, que Gautherot liga-se ao movimento. Suas fotografias, realizadas principalmente no Nordeste do país, são por vezes adquiridas por Carneiro para estudos, publicações ou exposições folclóricas. Gautherot comparava seu trabalho ao de conhecido figureiro nordestino, mestre Vitalino, que do barro criava cenas marcantes da vida cotidiana, das comemorações. Tais peças, reconhecidas, passavam a fazer parte da própria realidade descrita.

O próprio Edison Carneiro, nas suas recomendações para a pesquisa do folclore ${ }^{83}$, insiste sobre a importância desses "registros mecânicos" na construção etnográfica, na medida em que "constituem um documento vivo da observação. [...] A fotografia ilustrativa de aspectos do folclore deve ter sempre caráter dinâmico - um movimento, uma ação e não uma pose ${ }^{\prime 84}$. Desdobrando essa argumentação sobre a imagem - já afirmada, como já se viu, nos seminários de Mauss -, Carneiro defende uma idéia de folclore que se opõe às compilações inertes, às cristalizações do arcaico e do tradicional. Fiel ao ideário marxista, próximo a folcloristas soviéticos, advoga que "o folclore reflete, à sua maneira, as relações de produção criadas entre os homens", em permanente processo de "recomposição"; "nutre-se dos desejos de bem-estar econômico, social e político do povo e por isso tem implicações no futuro, como instrumento rudimentar de reivindicação social" 85 . "Através do folclore, o povo se faz presente na sociedade, se afirma no âmbito da superestrutura ideológica e nela encontra a sua tribuna" ${ }^{80}$.

Gautherot, simpatizante do partido proletário, compartilha dessas idéias e desse entusiasmo. Nas suas fotografias busca articular dialeticamente
60. ANDRADE, 1981

61. Mário de Andrade fora diretor do Departamento de Cultura da Municipalidade de São Paulo (1935-1938) e assistente técnico do SPHAN em São Paulo (19371938). Cria a Sociedade de Etnografia e Folclore (1936-1938), em São Paulo, reunindo intelectuais eminentes como Emilio Willens, Fernando deAzevedo e alguns estrangeiros, contratados para a Universidade de São Paulo, como Pierre Monbeig, Claude e Dinah LéviStrauss, Roger e Paul Arbousse Bastide. Foram realizadas, nessa sociedade, cursos e pesquisas com a participação ativa de Dinah Lévi-Strauss que fora pesquisadora assistente no Musée de 1'Homme. Nos Boletins da Sociedade (foram publicados sete números), a professora define "instruções e questionários" para a pesquisa de campo, orientando o trabalho de localização, observação e registro textual e iconográfico. Há um especial interesse na representação cartográfica de fenômenos humanos. Como nos estudos geográficos, recomendam-se fotografias e desenhos na coleta de dados. Cf. MARIO de Andrade... 1983

62. Nas Cartas de traba lho (ver nota 60), defende que, nas incursões de trabalho, se levasse o fotógrafo, "(um excelente e bem pago) para tirar as fotografias possíveis (questão da luz) e industriá-lo bem sobre as outras a tirar, quando refizesse a viagem sozinho, buscando luz mais propícia..." (p. 67)

63. Id., p. 76

64.A missão reuniu 1.126 fotografias, hoje depositadas no Centro Cultural 
São Paulo, realizadas, na sua maior parte, por Germano Graeser, Luis Saia, Edison Carneiro, Mozart Guarnieri, Donald Pierson. A esse respeito ver: AZEVEDO, 2000, p. 78 129.

65. Cf. VELLOSO, 1992, p. 26.

66. Cf. THIESSE, 1999, p. 16.

67. Na listagem dos monumentos em Ouro Preto que deverão ser fotografados (Ministério da Educação e Saúde/SPHAN, c. 1945) pode-se ler: "[...] Igreja Santa Ifigênia do Alto da Cruz: armar andaime e fotografar a imagem do nicho no conjunto, vendo-se a data 1762 , e nos pormenores as cabeças dos anjos, da Santa e do menino. Matriz do $\mathrm{Pi}$ lar: fotografar o oratório sobre a cômoda da sacristia e, separadamente, as 2 cabeças de querubins; o conjunto da sacristia, trindade no retábulo da capela mor: primeiro visto de frente e depois vista de cada lado, das sacadas das tribunas. São Francisco de Assis: conjunto do arco cruzeiro com os dois púlpitos, vendo-se ao fundo o retábulo da capela-mór; os dois púlpitos separadamente inclusive pormenores dos baixos-relevos das taças; o conjunto do retábulo da capela-mór visto um pouco de lado $\mathrm{e}$ de baixo; novo pormenor da coluna inteira do chão ao entablamento (inclusive) e bastante de lado para acentuar-lhe o perfil construtivo. Conviria nesta foto, afastar o consolo para a parede. Pormenor do coroamento do retábulo com a Santíssima Trindade, o conjunto da igreja vista do coro, vendo-se o forro e a capela-mór ao fundo; o lavatório da sacristia sem os anjos $[\ldots]$. Nova Lima [...] o sacrário abrangendo as respecti-
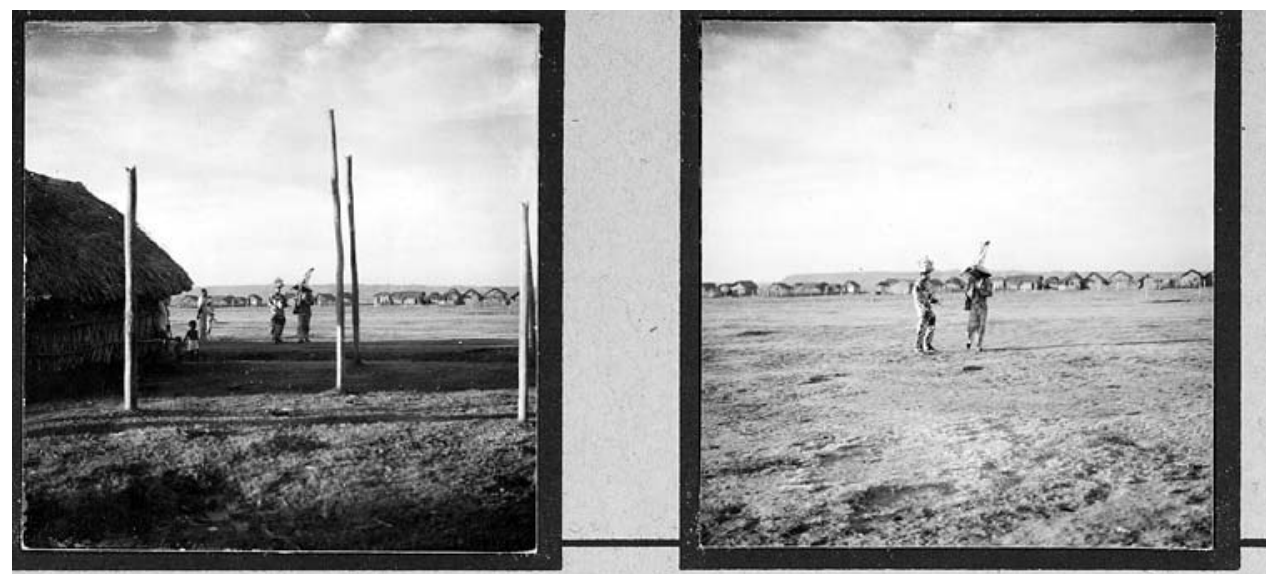

13936
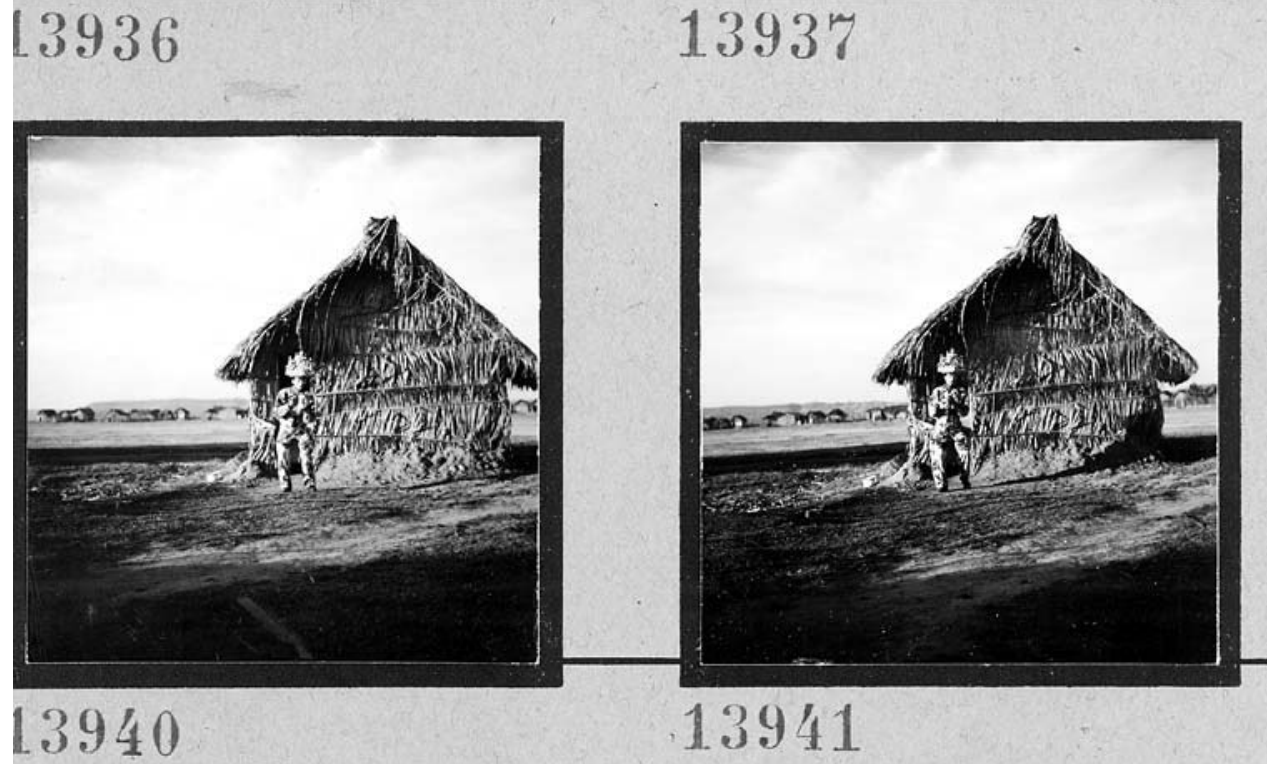

13941

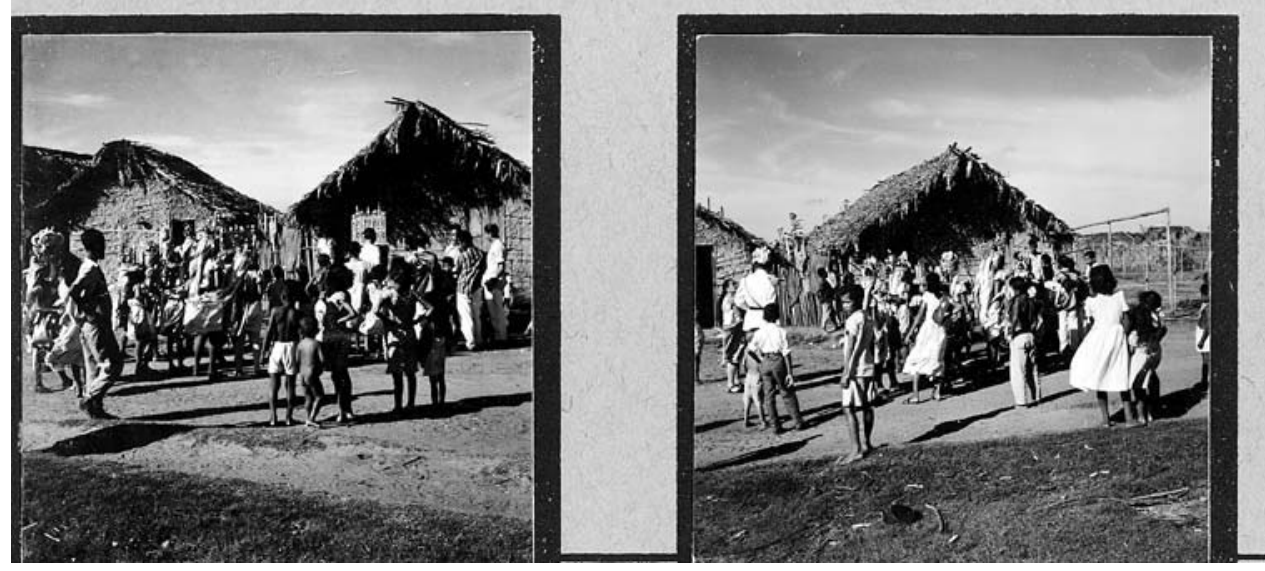

Figura 6 - Guerreiros, Maceió/AL, c. 1943. Fotografias de Marcel Gautherot. Acervo do Instituto Moreira Salles. 

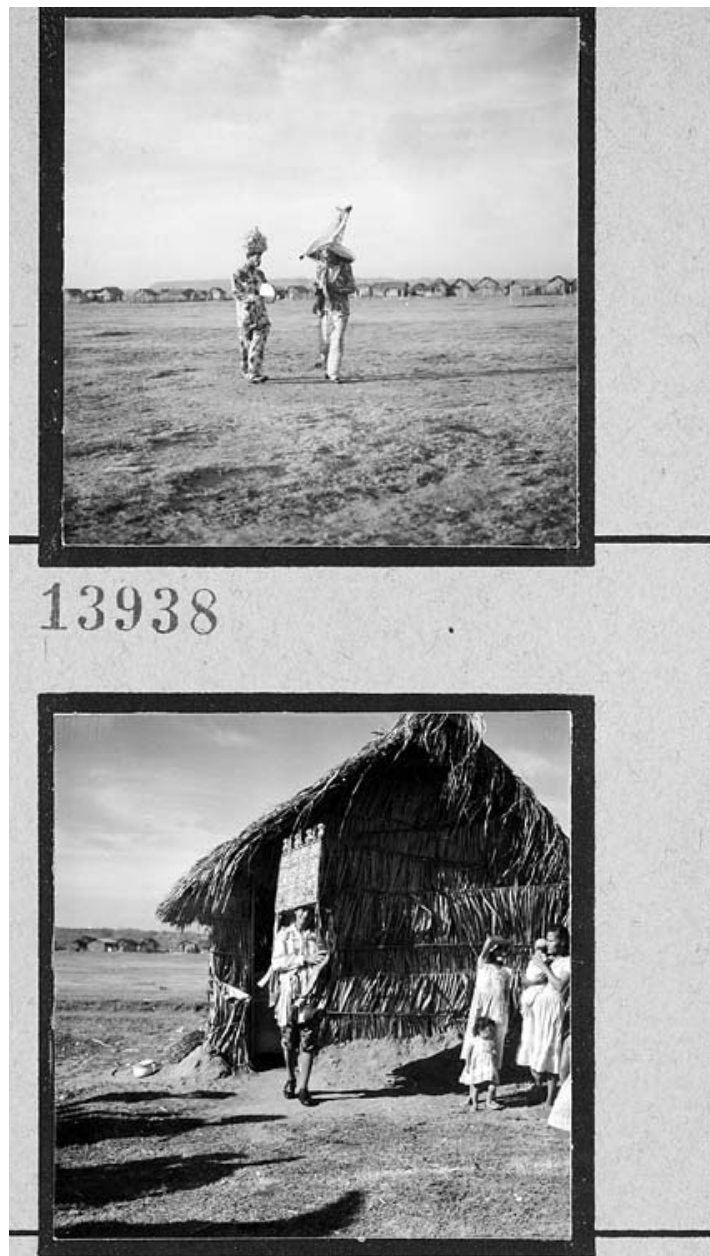

13942
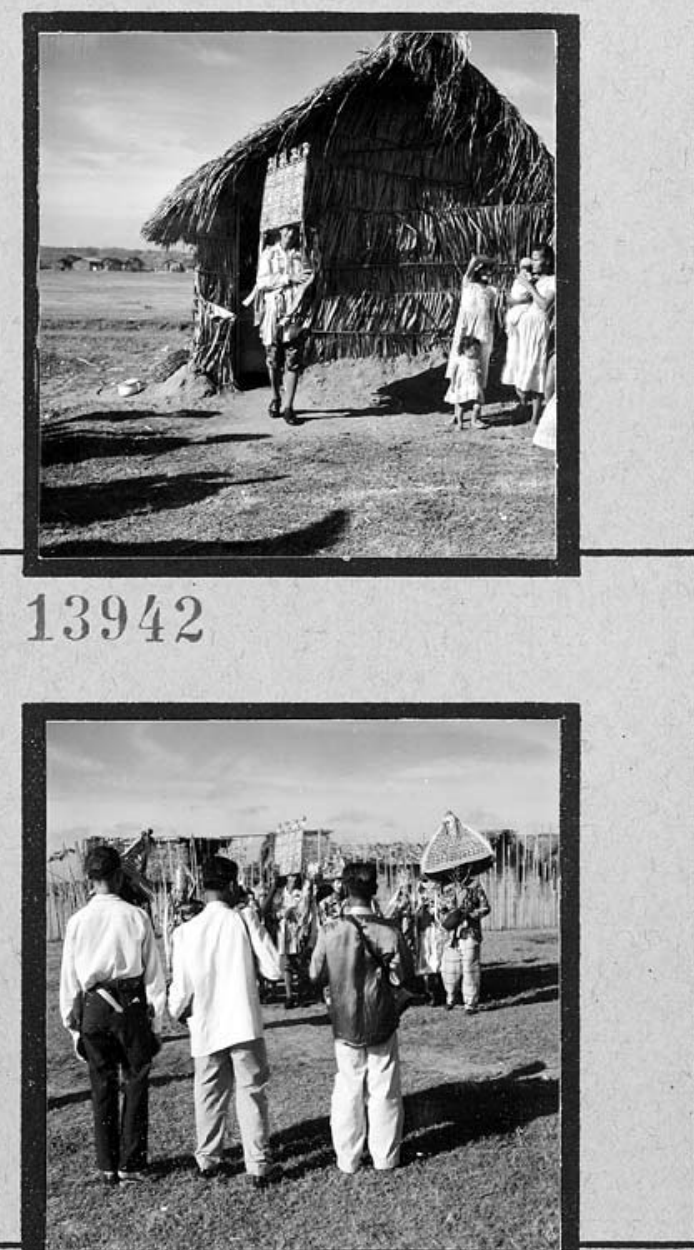

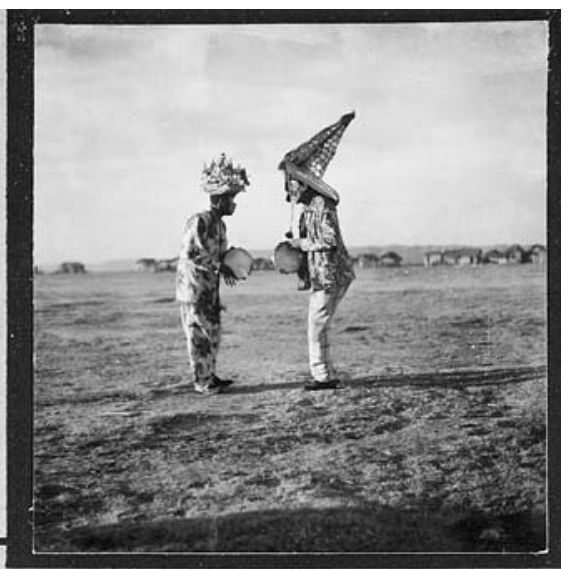

13939

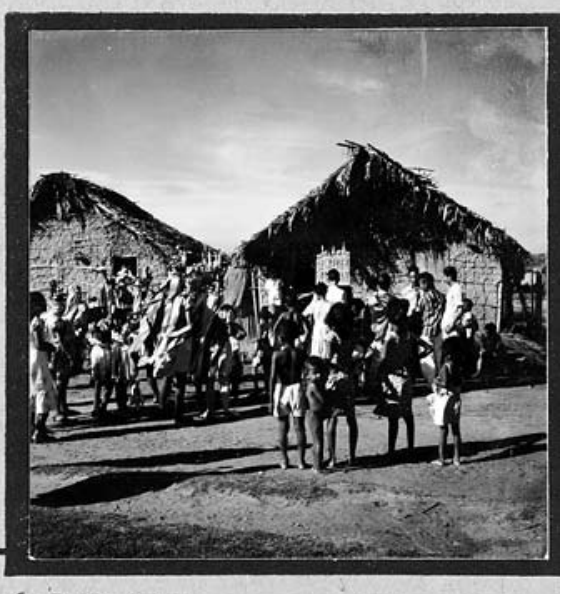

13943

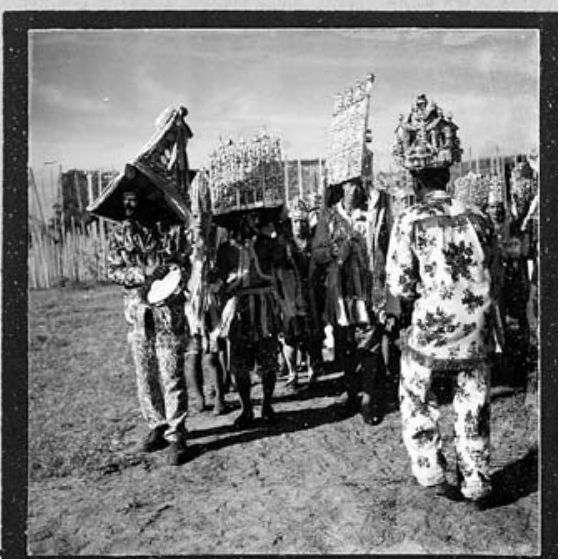

vas volutas laterais (desarticular primeiro o suporte da cortina afim de removê-la completamente); uma das colunas dos retábulos dos altares laterais vista de baixo e de lado, inclusive a mísula com o mesmo propósito de atentar a sinuosidade característica (retirar primeiro o socket da lâmpada do seu fuste), o púlpito sem se ver a grade da escada [...]."MINISTÉRIO, 19451956.

68. Do mesmo documento anterior, seguem as instruções para o trabalho em Catas Altas (MG):"fotografar o Cristo que se achava no corredor da tribuna da capela-mór do lado do Evangelho, procurando acentuar-lhe o caráter possante e dominador, sem contudo deformar o braço próximo da objetiva. Pormenores das mãos e dos pés".

69. Interessa ver, adiante na pesquisa, o uso dessas imagens na Revista do SPHAN e outras, a recorrência das fotos escolhidas, os cortes de edição, a retangularização da imagem, (originalmente quadrada), na relação com o texto.

70. NOBRE, 2001, p. 16.

71."Je suis tout occupé à photographier des détails d'architecture, poursuivi de place en place par une bande de négrillons à demi nus qui me supplient: tira o retrato ! tira o retrato ! A la fin, touché par une mendicité si gracieuse - une photo qu'il ne verraient jamais plutôt que quelques sous - j'accepte d'exposer un cliché pour contenter les enfants. Je n'ai pas marché cent mètres qu'une main s'abat sur mon épaule: deux inspecteurs en civil, qui m'ont suivi pas à pas depuis le début de ma promenade, m'in- 
forment que je viens de me livrer à un acte hostile au Brésil: cette photo, utilisée en Europe, pouvant sans doute accréditer la légende qu'il y a des Brésiliens à peau noire et que les gamins de Babia vont nu-pieds. Je suis mis en état d'arrestation, pour peu de temps heureusement, car le bateau va partir ". (LÉVISTRAUSS, 1955,p.29-30).

72.A Revista Brasileira de Geografia, desde 1939, abre uma seção com esse título, onde "os matizes naturais e humanos mais característicos e típicos das diferentes regiões do país 'são entrevistos através de magníficas ilustrações de Percy Lau'". Nota explicativa da $5^{a}$ edição. IBGE/Conselho Nacional de Geografia. Tipos e aspectos do Brasil. Excerto da Revista Brasileira de Geografia. Rio de Janeiro, 1956.

73. EDWARDS, op. cit., p.

74. CLIFFORD, 1994, p.
72.
75. Foram incorporadas
ao livro, complementar-
mente, algumas poucas
fotografias de R. P. Secon-
di e Hesse, do Rio de Ja-
neiro; do Office du Bré-
sil, de Paris e de Pierre

74. CLIFFORD, 1994, p.
72.
75. Foram incorporadas
ao livro, complementar-
mente, algumas poucas
fotografias de R. P. Secon-
di e Hesse, do Rio de Ja-
neiro; do Office du Bré-
sil, de Paris e de Pierre

74. CLIFFORD, 1994, p.
72.
75. Foram incorporadas
ao livro, complementar-
mente, algumas poucas
fotografias de R. P. Secon-
di e Hesse, do Rio de Ja-
neiro; do Office du Bré-
sil, de Paris e de Pierre

74. CLIFFORD, 1994, p.
72.
75. Foram incorporadas
ao livro, complementar-
mente, algumas poucas
fotografias de R. P. Secon-
di e Hesse, do Rio de Ja-
neiro; do Office du Bré-
sil, de Paris e de Pierre

74. CLIFFORD, 1994, p.
72.
75. Foram incorporadas
ao livro, complementar-
mente, algumas poucas
fotografias de R. P. Secon-
di e Hesse, do Rio de Ja-
neiro; do Office du Bré-
sil, de Paris e de Pierre

74. CLIFFORD, 1994, p.
72.
75. Foram incorporadas
ao livro, complementar-
mente, algumas poucas
fotografias de R. P. Secon-
di e Hesse, do Rio de Ja-
neiro; do Office du Bré-
sil, de Paris e de Pierre

74. CLIFFORD, 1994, p.
72.
75. Foram incorporadas
ao livro, complementar-
mente, algumas poucas
fotografias de R. P. Secon-
di e Hesse, do Rio de Ja-
neiro; do Office du Bré-
sil, de Paris e de Pierre

74. CLIFFORD, 1994, p.
72.
75. Foram incorporadas
ao livro, complementar-
mente, algumas poucas
fotografias de R. P. Secon-
di e Hesse, do Rio de Ja-
neiro; do Office du Bré-
sil, de Paris e de Pierre

74. CLIFFORD, 1994, p.
72.
75. Foram incorporadas
ao livro, complementar-
mente, algumas poucas
fotografias de R. P. Secon-
di e Hesse, do Rio de Ja-
neiro; do Office du Bré-
sil, de Paris e de Pierre Monbeig.

76.Trata-se da mesma coleção em que fora publicado o trabalho de Verger sobre o México, indicado anteriormente. Certamente foi Verger que intermediou a publicação desse novo título.A tradução do livro é publicada no Brasil, em 1952, pela Livraria Agir Editora, Rio de Janeiro. Incorpora, à relação de imagens já publicadas em Paris, fotos de José Medeiros e de Boer, de São Paulo.
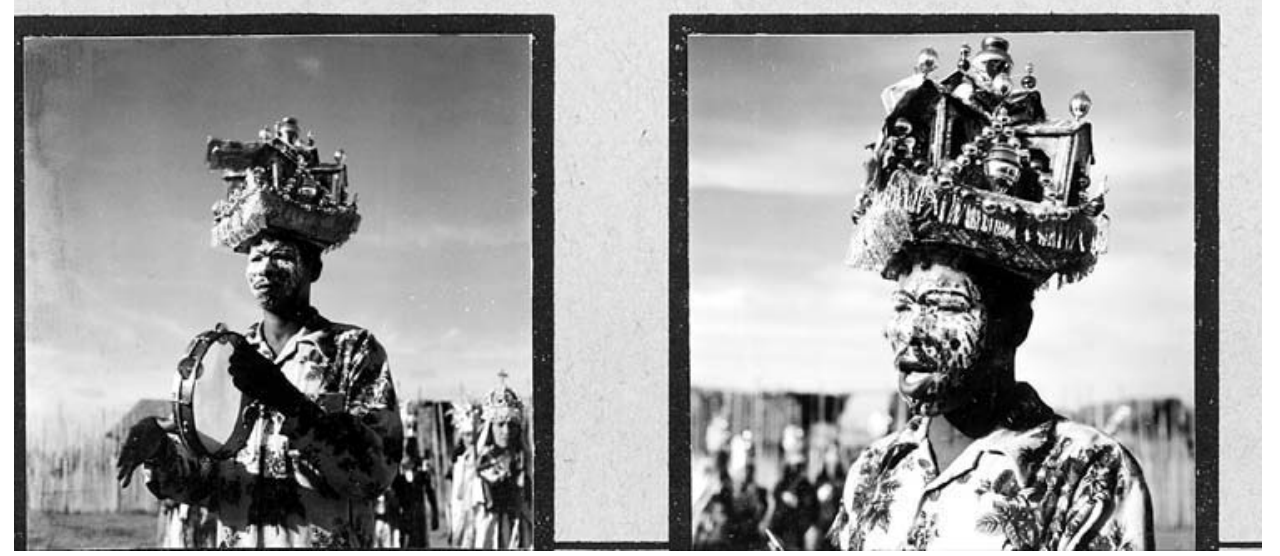

Figura 7 - Guerreiros, Maceió/AL, c. 1943. Fotografias de Marcel Gautherot. Acervo do Instituto Moreira Salles.
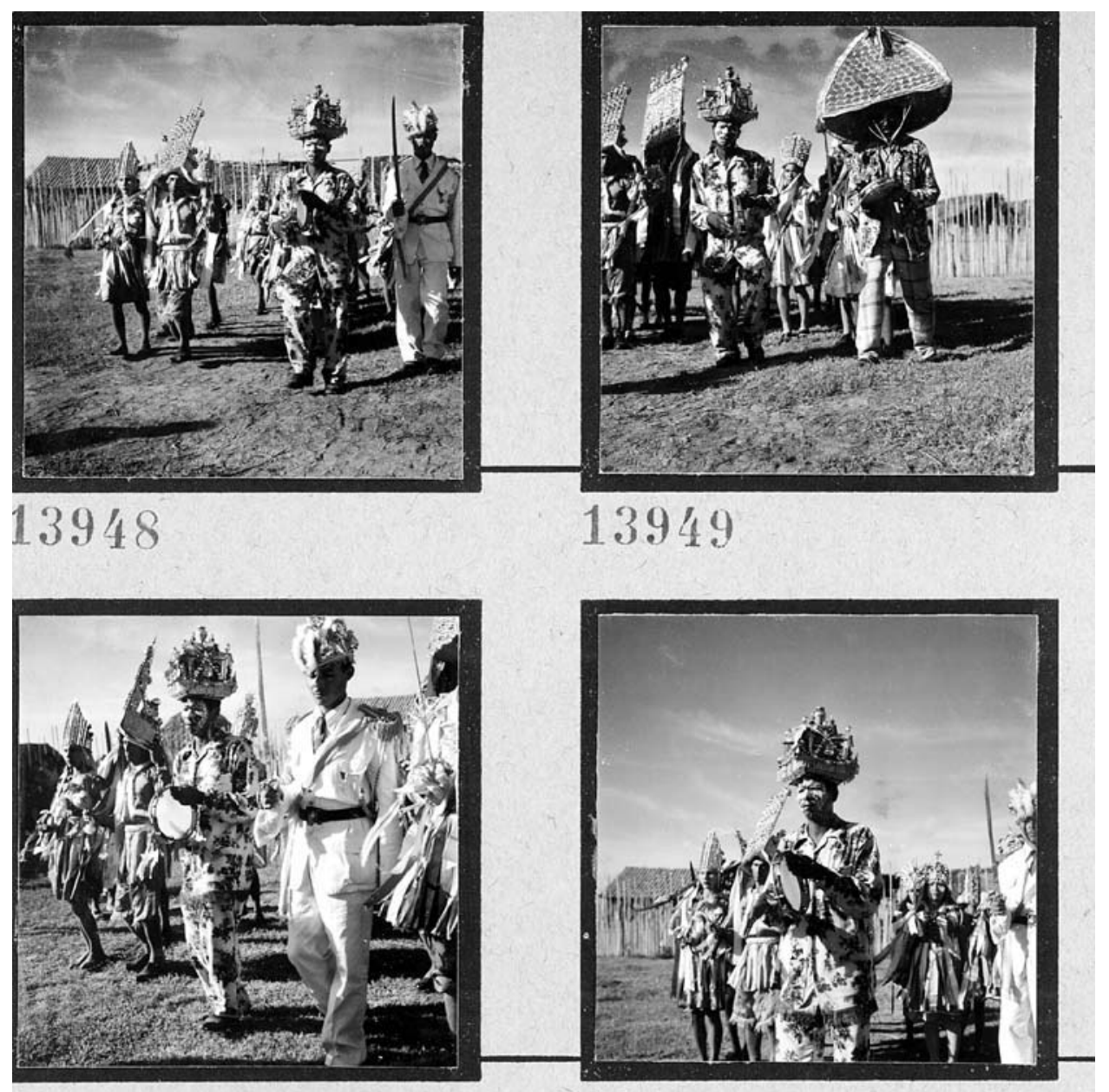

1.3952

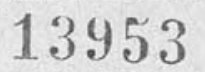



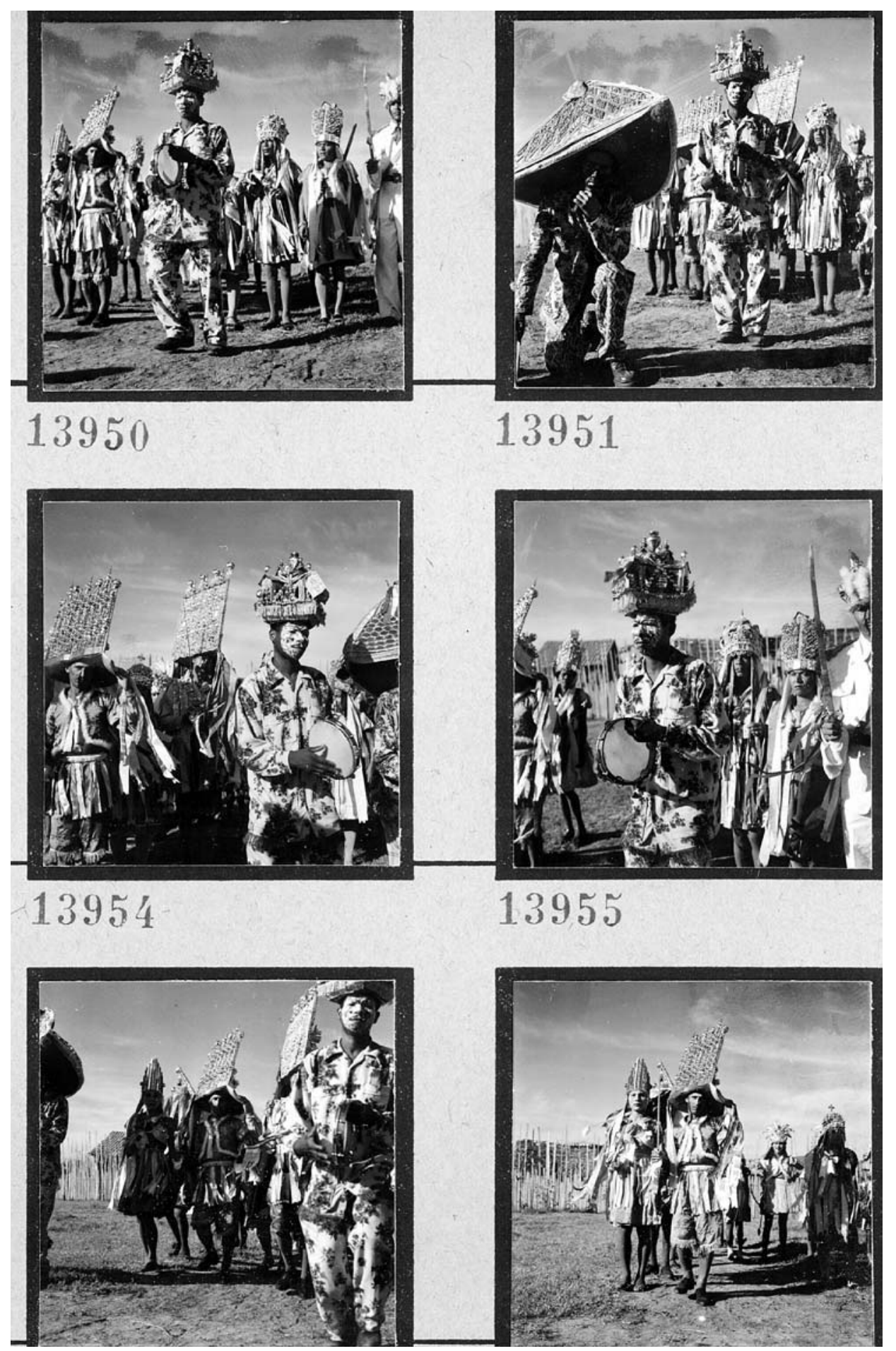

77. Esse livro e o Brazil da Life World Library, publicado em 1962, também com algumas fotos de Gautherot, são títulos de referência sobre a representação iconográfica do país, para leitores estrangeiros, dentro do recorte cronológico (19401960) dessa pesquisa em andamento.Terão um estudo comparativo adiante que contemplará ainda outros trabalhos do fotógrafo feitos para o Ministério de Relações Exteriores do Brasil.

78. Um estudo específico sobre o trabalho fotográfico de Gautherot, ligado à Campanha de Defesa do Folclore Brasileiro, foi por mim apresentado no seminário do projeto - já indicado por Heliana Salgueiro - realizado em junho de 2005, na École des Hautes Études en Sciences Sociales, Paris.

79. CARNEIRO, 1950.

80. SEGALA,op.cit.,p. 47. 81. VILHENA, 1997,p. 173. 82. VILHENA, op.cit., p. 106.

83. CARNEIRO, 1965, p. 131-156.

84. Id., p. 131-156.

85. Ibid, p. 57.

86. Ibid, p. 22. 


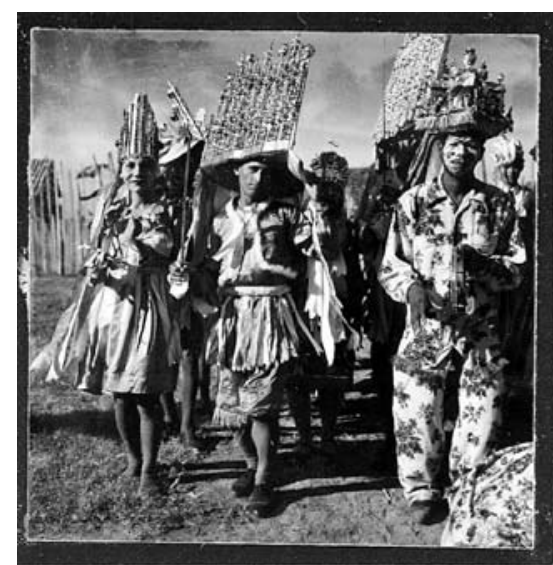

13960

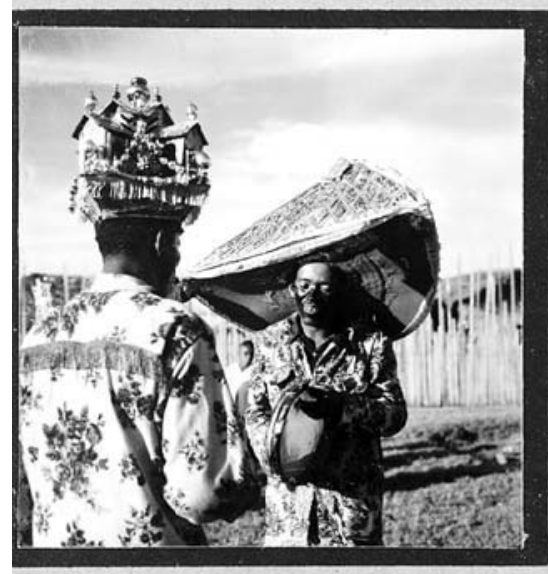

13964

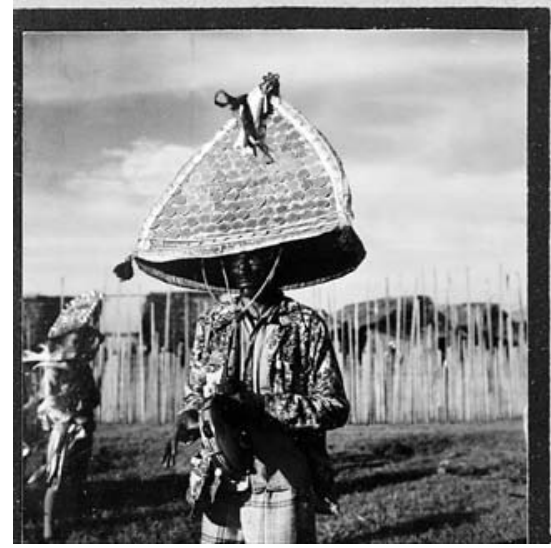

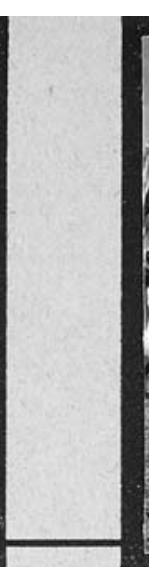

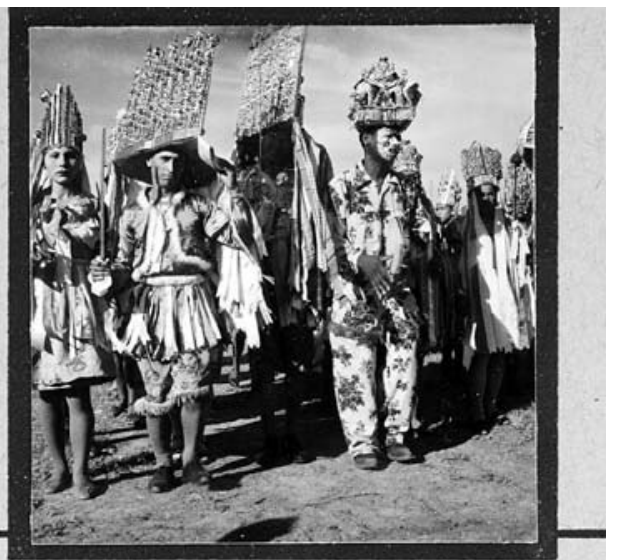

13961

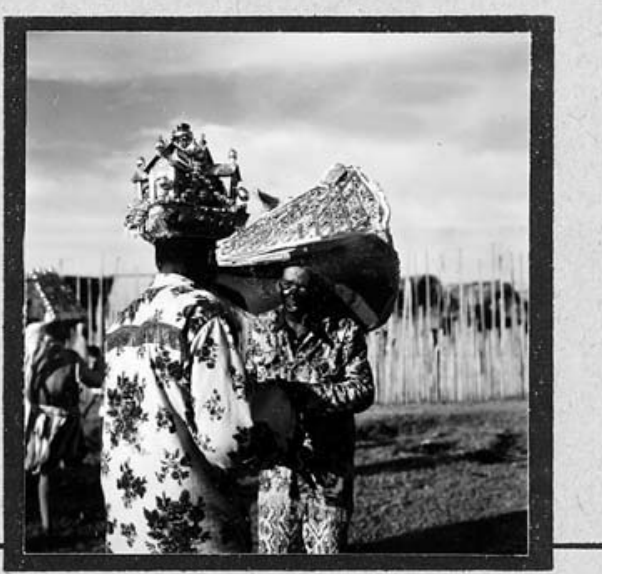

13965

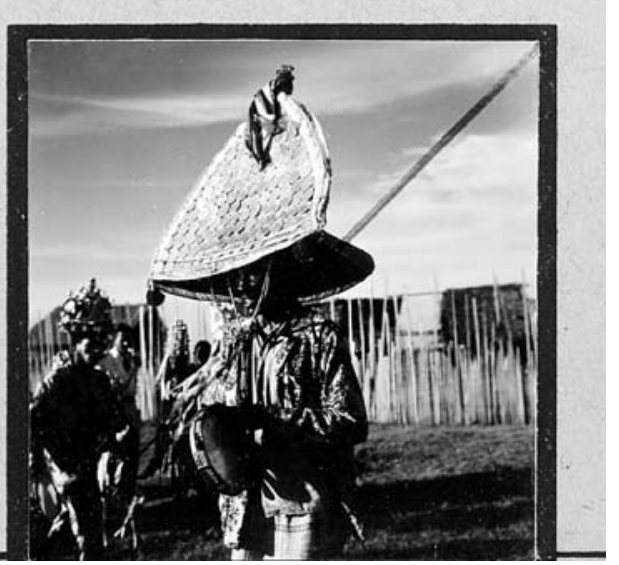

Figura 8 - Guerreiros, Maceió/AL, c. 1943. Fotografias de Marcel Gautherot. Acervo do Instituto Moreira Salles. 


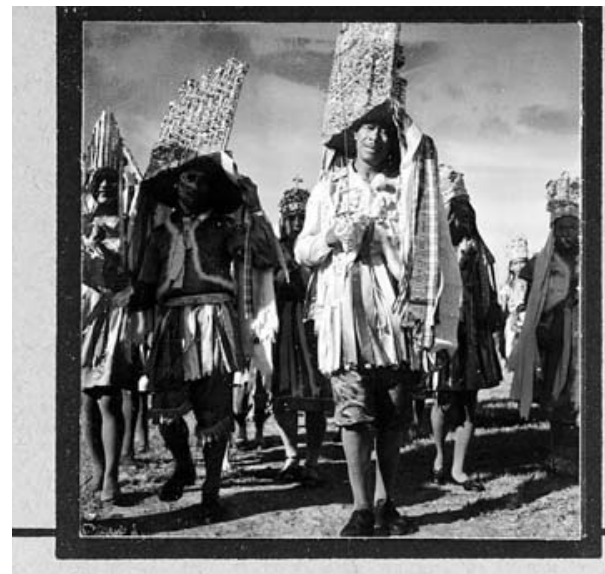

13962

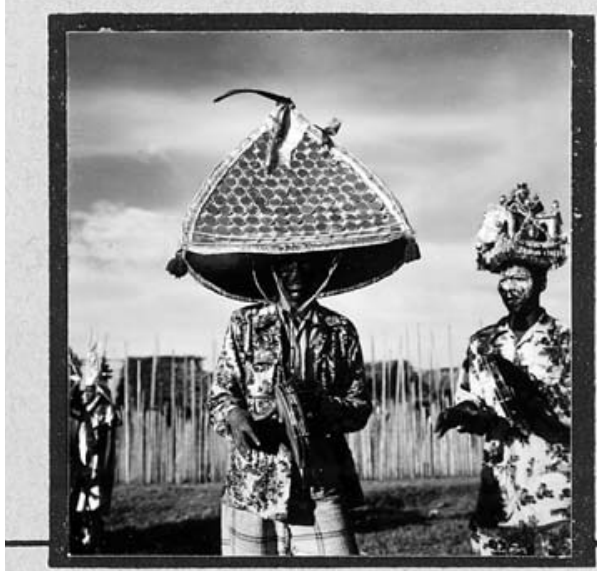

13966

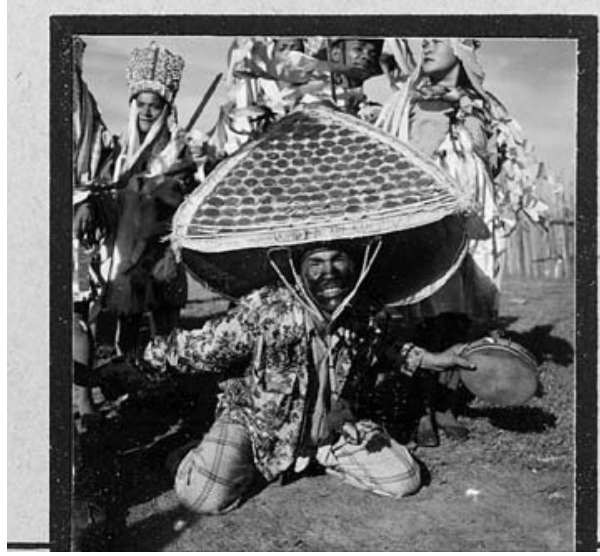

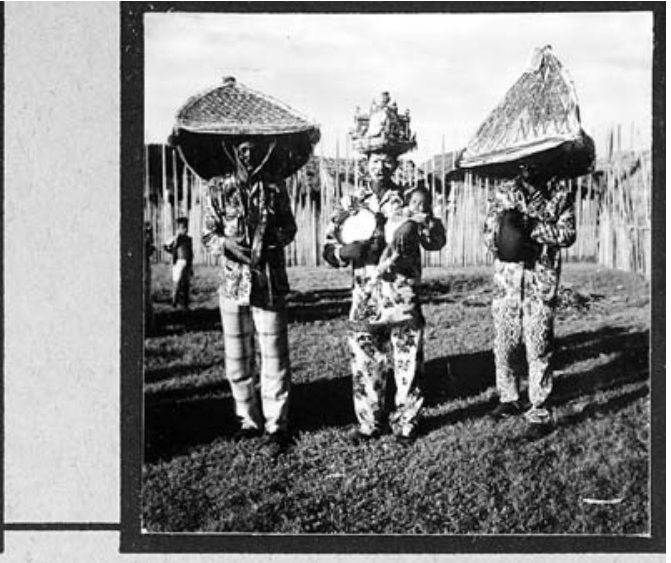

13963
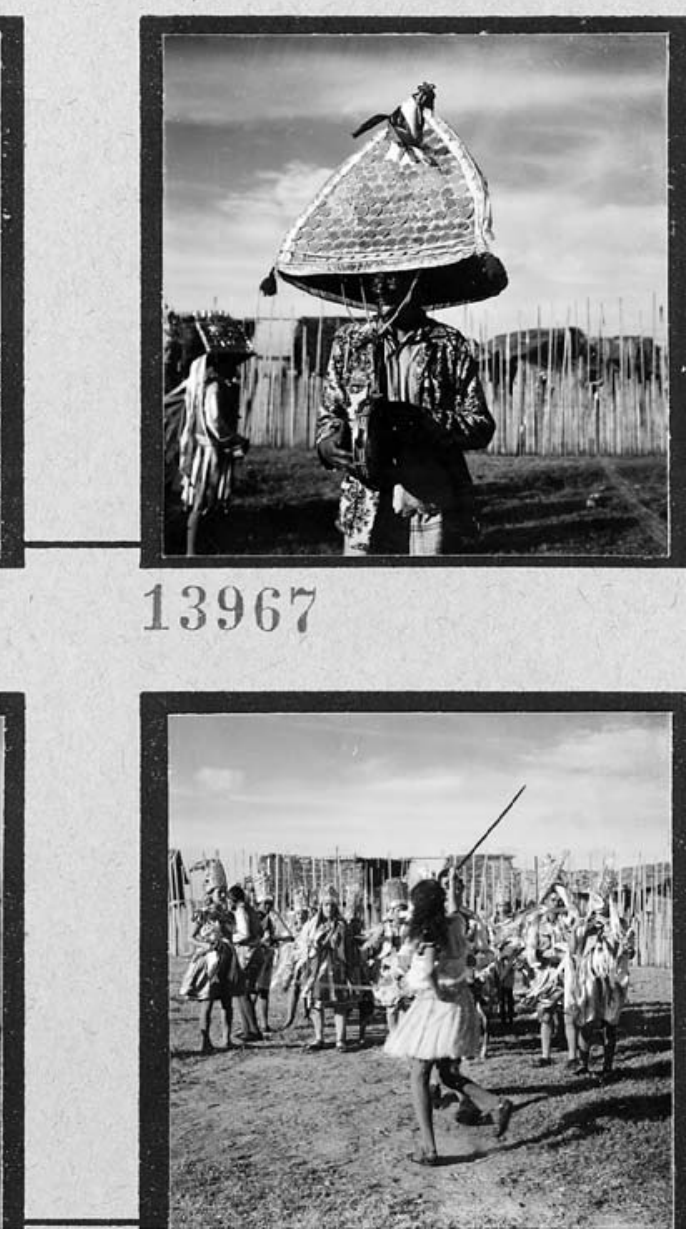
87. Com o afastamento de Edison Carneiro da Campanha pelo golpe militar de 1964, Gautherot passa a ter com o movimento laços mais eventuais.

88. Sobre convencionalização e poder de convicção ver CANDIDO, 2004 p. $70-80$.

89. Especialmente nos escritos de José de Alencar. A destacar $O$ gaúcho (1870) e O sertanejo (1875).

90. A destacar, os desenhos de Flumen Junius no livro de Mello de Moraes Filho, Festas e tradições populares do Brasil, de 1895.

91. PONTES, 2001, p.419476.

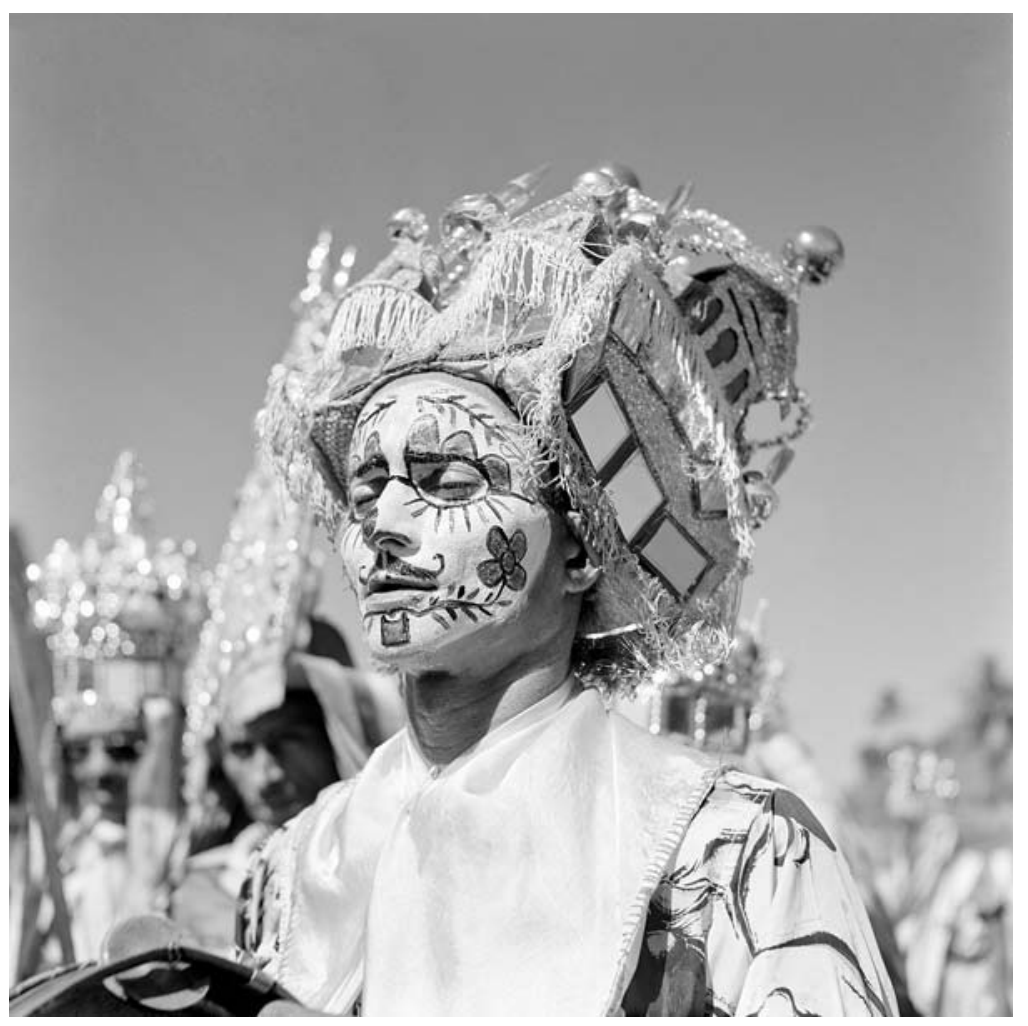

Figura 9 - Guerreiros, Maceió/AL, c. 1943. Fotografia de Marcel Gautherot. Acervo do Instituto Moreira Salles.

essa dimensão mais celebrativa e poética, à documentação da dinâmica dessas criações populares ${ }^{87}$.

É importante refrisar que as séries fotografadas por Gautherot, como outras feitas por fotógrafos dos anos 1930 -1940, interessados em enquadrar o Brasil, com o apoio de certas instituições públicas, recriam e estabilizam representações que vinham sendo escolhidas e convencionalizadas ${ }^{88}$ nas descrições textuais e iconográficas desde o século XIX. São referências para as paisagens e para os sítios urbanos, roteiros de observação e de registro apresentados em álbuns litográficos e fotográficos oitocentistas. Da mesma forma, os tipos regionais, as artes e festas populares, as "infiltrações entre o tipo humano e as paisagens", nos termos de Antonio Candido, definem-se em redes de apropriações calçadas na literatura romântica ${ }^{89}$, nos estudos de folclore e das tradições populares ${ }^{90}$, nos trabalhos emblemáticos de Euclides da Cunha (1902), de Roquete Pinto (especialmente Rondônia de 1917), em projetos expositivos do Museu Nacional, nos "quadros" da geografia humana, no temário da pintura moderna, no trabalho de ilustradores e copistas das coleções de títulos sobre o país, nos anos 1930 -1950, como Anita Malfatti, Tarsila do Amaral, Clóvis Graciano, Di Cavalcanti, Portinari, Tomás Santa Rosa entre outros ${ }^{91}$.

No arquivo de Gautherot, há séries - algumas encomendadas, ligadas 
provavelmente a projetos de exposições - em que essas conexões podem ser apreendidas. Fotografa o trabalho de gravadores, litógrafos, fotógrafos, pintores e escultores já consagrados ou em processo de consagração como intérpretes autorizados do Brasil. Apresentam, por um princípio de diferenciação, a nação ilustrada, fixando hierarquias de significado e de valor, produzindo seus referentes como "testemunhos" visíveis de uma história e de uma tradição a serem aprendidas e compartilhadas 92 .

Gautherot revela de suas viagens fotográficas centenas de negativos, um acervo de referência para outros investimentos que faz nas áreas do fotojornalismo, da documentação arquitetônica e etnográfica. Investe durante anos na produção e na organização do seu acervo fotográfico pessoa ${ }^{93}$. Ao ordenar e classificar, ele edita o seu material eliminando redundâncias, a partir de um sistema enunciador que rege a aparição singular de seqüências factuais e simbólicas que importam ver. Na organização física do arquivo, os negativos foram separados, escolhidos e descartados. Da mesma forma, os seus contatos - imagens indiciais de consulta - foram recortados, corrigidos um a um e colados, definindo uma orientação de leitura ${ }^{94}$. Ainda que algumas de suas fotos tenham se tornado ícones do patrimônio cultural brasileiro, reproduzidas em diferentes galerias e publicações institucionais, o estudo das folhas de contato, organizadas pelo fotógrafo é fundamental para a compreensão do seu trabalho autoral, da lógica relacional de suas imagens, das expectativas suas quanto aos usos das imagens (Figuras 10 -14).

A distância, porém, entre o tempo de produção e acumulação de negativos, marcado pela lógica particular das encomendas, das viagens e dos recursos disponíveis e o tempo de organização do arquivo, possibilitou a recriação de séries fotográficas. Qual seja, esse seu trabalho retrospectivo, pautado pelo exercício presente das lembranças e de projetos, redefine a experiência ordenada do registro, a precisão da cronologia, abrindo certos segmentos de "ficção documentária", reconstituições a posteriori, do senso explicativo das imagens ${ }^{95}$.

Gautherot volta várias vezes aos mesmos lugares, completando informações de maneira exaustiva, precisando, na sua edição, séries ${ }^{90}$, narrativas visuais (Figuras 15-17). O itinerário refletido pela fotografia aguça a observação. Essa insistência em mesmos percursos, realizados em tempos diferentes, às vezes muito próximos, embaraça o sentido, no acervo, das séries originais, sua datação precisa. Por vezes, é possível desmontar esses ensaios seqüenciais quando diferenças técnicas de produção, características do filme ou da câmera ou ainda especificidades de luz e de formas flagradas indicam registros fotográficos não seguidos no tempo. Esses arranjos de certa forma se autorizam porque a fotografia por princípio atualiza o "presente etnográfico".

Do ponto de vista conceitual, a produção do acervo - os procedimentos de separar, identificar, reunir, descartar - segue uma ordem particular, cruzando irregularmente os critérios geográfico, temático e cronológico ${ }^{97}$.

Gautherot dividiu os negativos e seus respectivos contatos por Estado brasileiro. As viagens de exploração, os lugares revisitados definem uma cartografia que privilegia o Norte e sobretudo o Nordeste do Brasil, também
92. A construção identitária da nação moderna pressupõe, como mostra Thiesse (op. cit., p. 14), operações de escolha e de articulação de elementos materiais e simbólicos proclamados como sinais diacríticos no quadro das representações internacionais e ainda a produção de sua legitimidade como patrimônio comum.

93. As observações a seguir, sobre o acervo de Gautherot, calçam-se nas informações prestadas por Sérgio Burgi, em entrevista que me concedeu em 17/5/2004, no IMS, Rio de Janeiro e na comunicação que fez na jornada de estudos, coordenada por Heliana Salgueiro e por mim, no Programa de Pós-graduação em Antropologia da Universidade Federal Fluminense, em 14/12/2004.

94. Sérgio Burgi indica que "além da qualidade fotográfica sempre muito boa, Gautherot fazia correções inclusive na qualidade dos fotogramas que ele coloca nos contatos. Os contatos, via de regra, não têm nenhum defeito de sub ou super exposição na imagem que você está vendo. Ele trabalhou os contatos individualmente. Não são tiras copiadas, recortadas e coladas. Tem correção de exposição. Ele voltou ao laboratório, corrigiu. Ele passou 10 anos da vida organizando o arquivo. Isso é raro" (entrevista em 17/5/2004). Essa atenção particularizada aos fotogramas permitiu, como assinala Burgi, a realização de negativos de segunda geração, com alta qualidade, a partir dos contatos acumulados sem negativo original.

95. Conforme Burgi, "ele monta os contatos de uma forma super editada. 
Começa com as vistas gerais da praia, depois acompanha o jangadeiro que está chegando de manhã para sair, começa a preparar a jangada, abre as velas, ganha o mar... Evidente que ele fotografava de uma forma muito planejada, sistemática, mas certamente ele não planejou a série exatamente daquela maneira Quando colocamos juntos todos os negativos podemos ver onde é seqüência mesmo pelo corte e onde estão faltando trechos. É um quebra-cabeça." Até o momento, segundo Burgi, não foram feitos exames sistemáticos nos cortes dos negativos originais para a verificação de encaixes em seqüências. É importante notar que no período, os negativos não tinham numeração de fábrica o que dificulta o controle preciso das ordens seriais do filme e dos contatos.

96. A noção quantitativa de série se articula à produção, à geração e justaposição de imagens ou objetos fotográficos enquanto a de coleção remete à acumulação ordenada de imagens preexistentes. As séries, segundo Rouillé, recobrem dois conjuntos: o que define vistas em torno de um mesmo tema ou objeto e o que expõe reproduções de um mesmo clichê. Cf. ROUILLÉ, 1991, p. 6.

97. Parece incorporar aqui as referências para a organização de fotografias, utilizadas na fototeca do Musée de l'Homme, indicadas anteriormente. A atenção privilegiada aos critérios geográfico e temático dificulta a percepção clara dos momentos de produção.

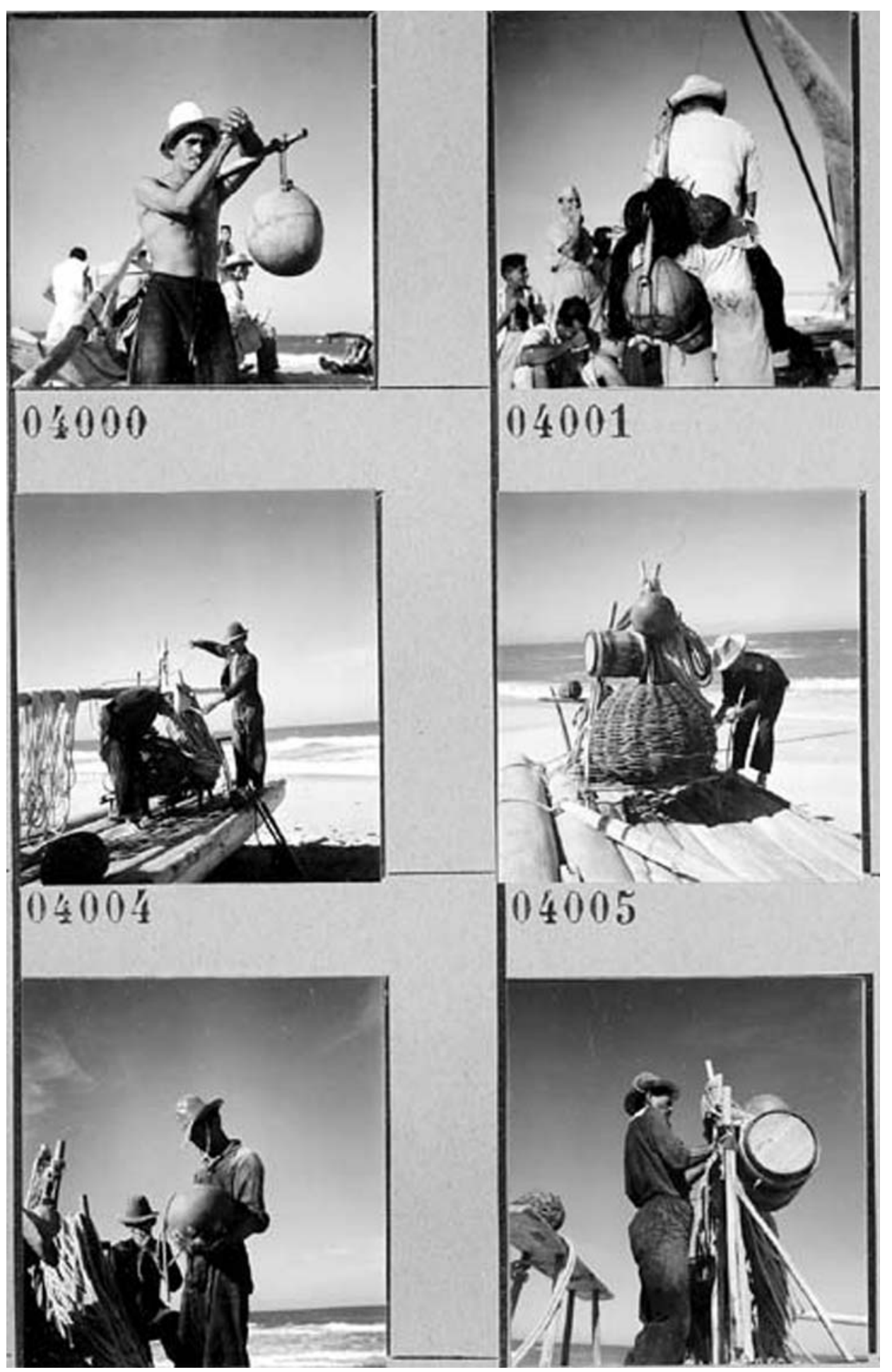

Figura 10 - Jangadas, Aquiraz/CE, c. 1950-1952. Fotografias de Marcel Gautherot. Acervo do Instituto Moreira Salles. 


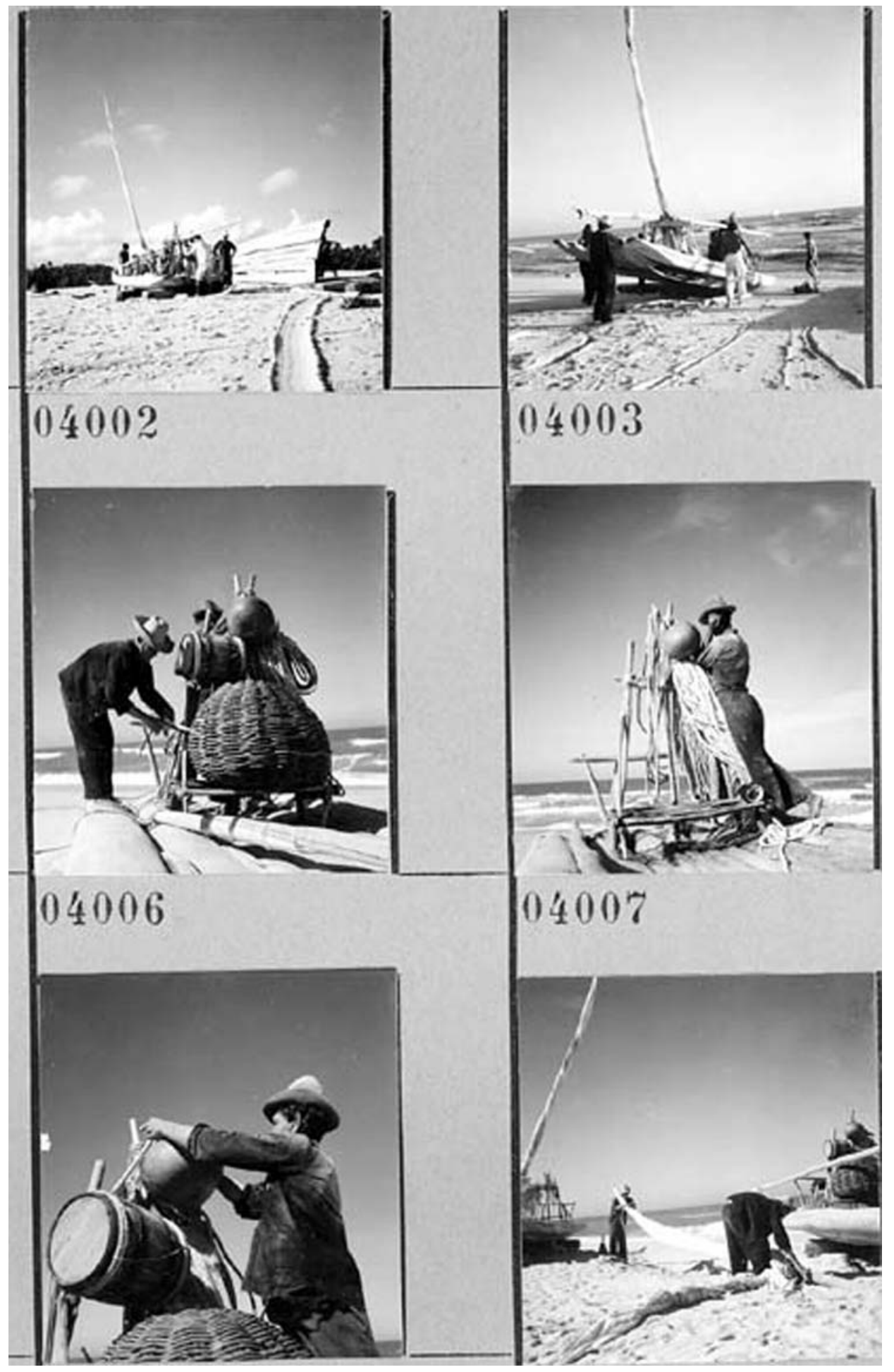

Annals of Museu Paulista.v. 13. n.2. Jul.- Dec. 2005. 


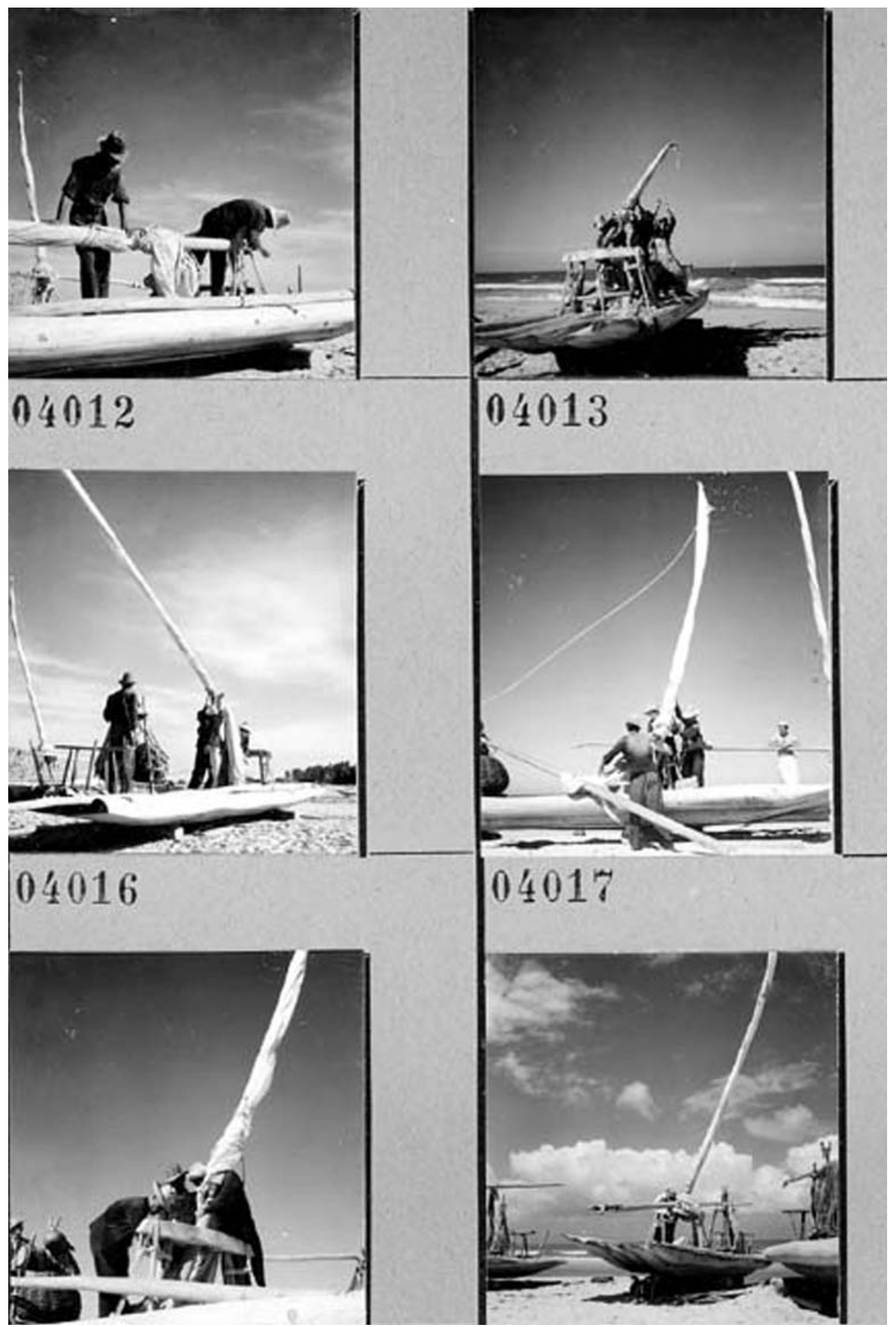

Figura 11 -Jangadas, Aquiraz/CE, c. 1950-1952. Fotografias de Marcel Gautherot. Acervo do Instituto Moreira Salles. 


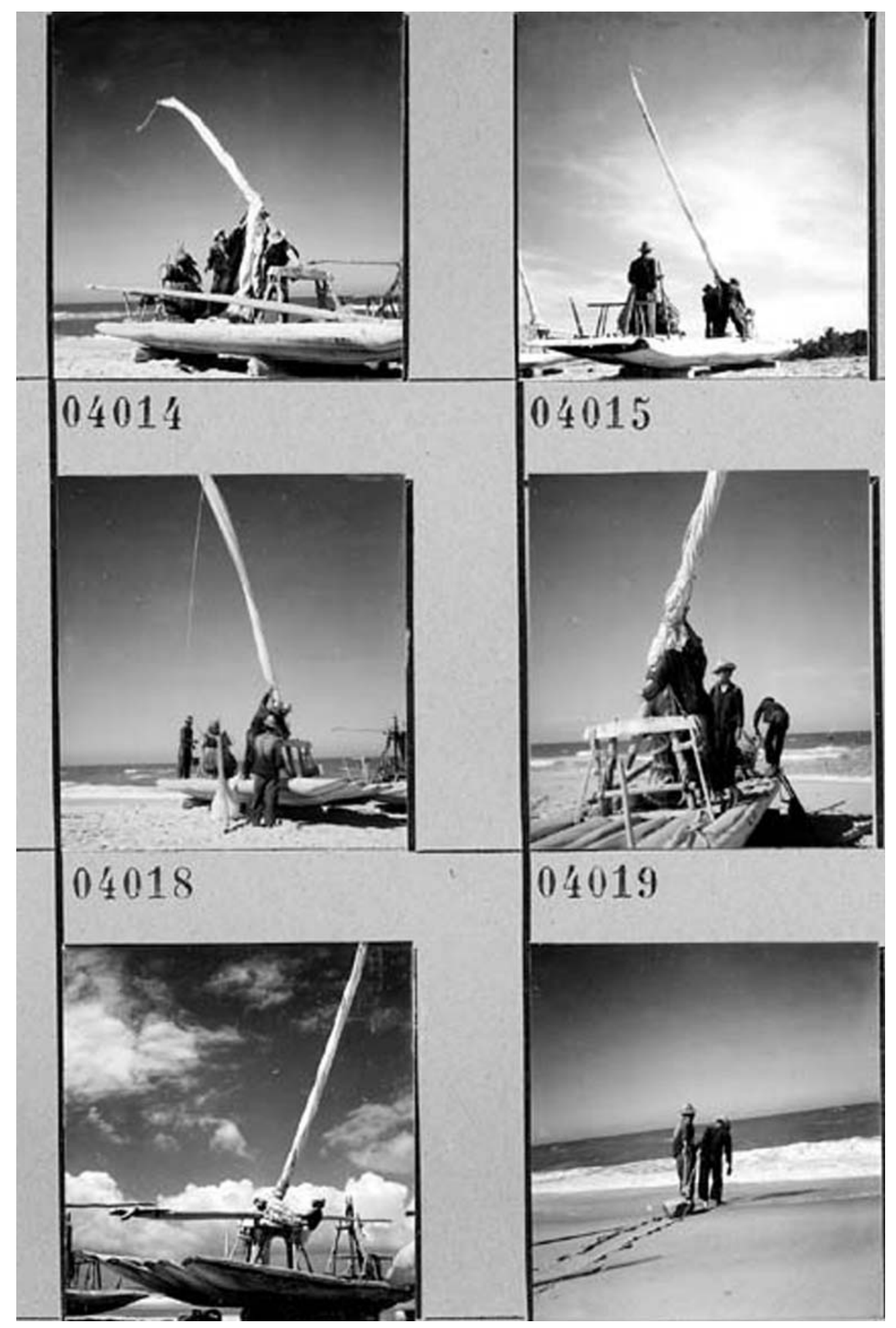

Annals of Museu Paulista.v. 13. n.2. Jul.- Dec. 2005. 


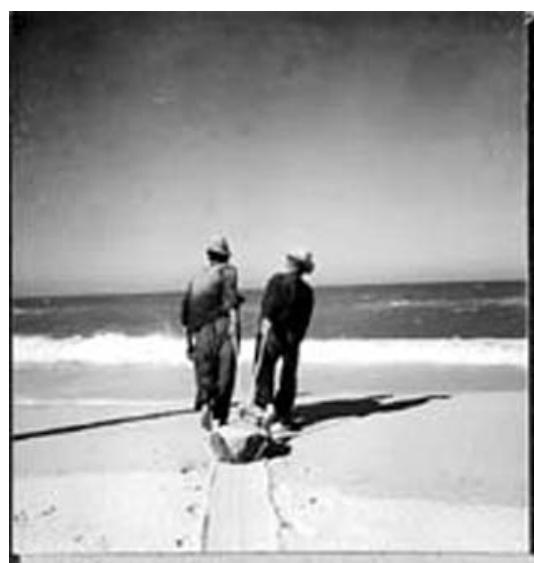

04024

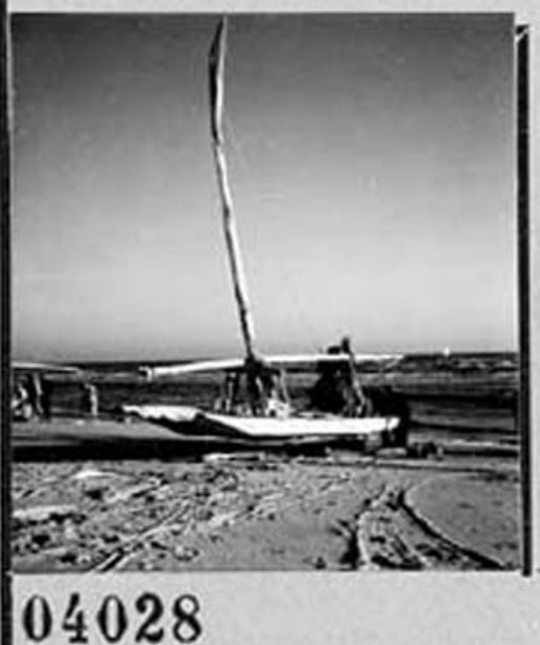

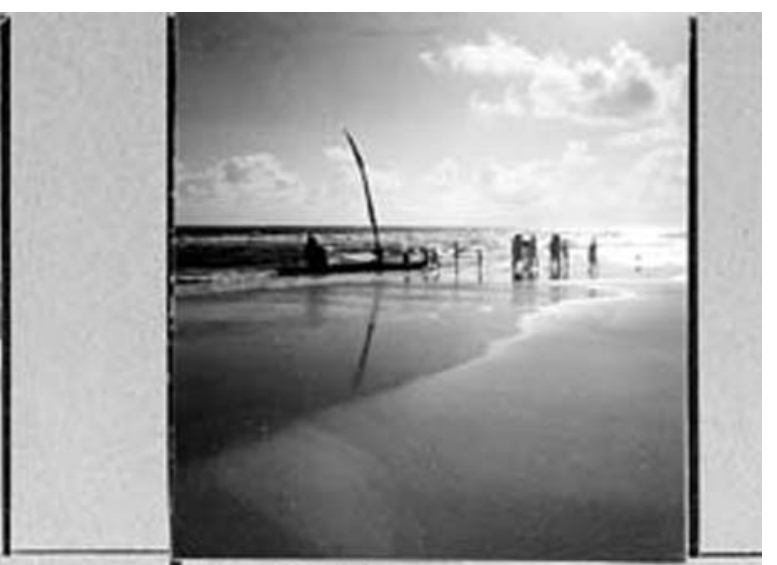

04025
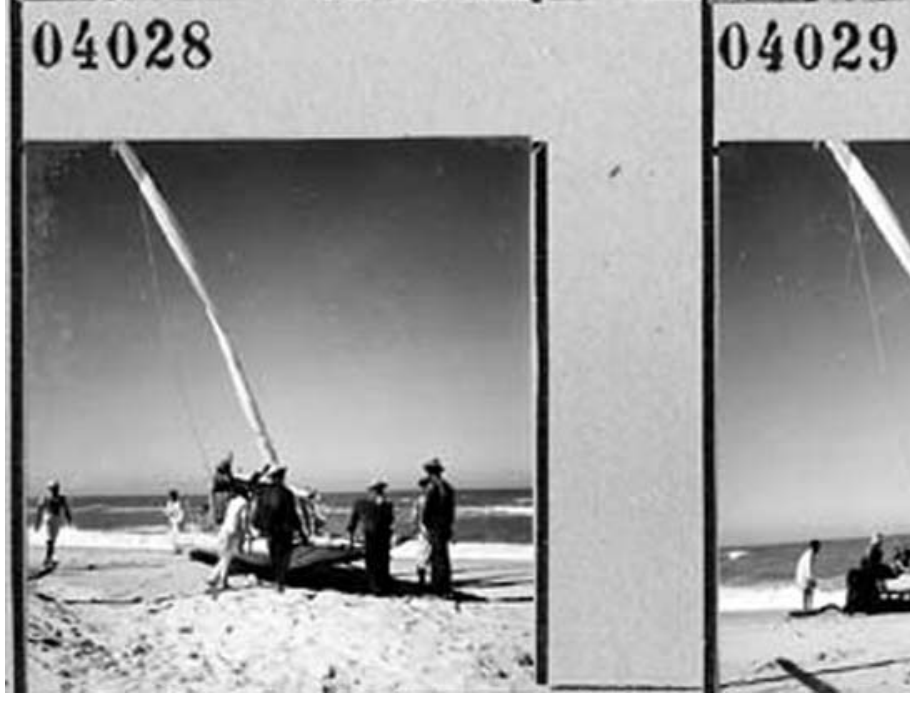

Figura 12 - Jangadas, Aquiraz/CE, c. 1950-1952. Fotografias de Marcel Gautherot. Acervo do Instituto Moreira Salles. 


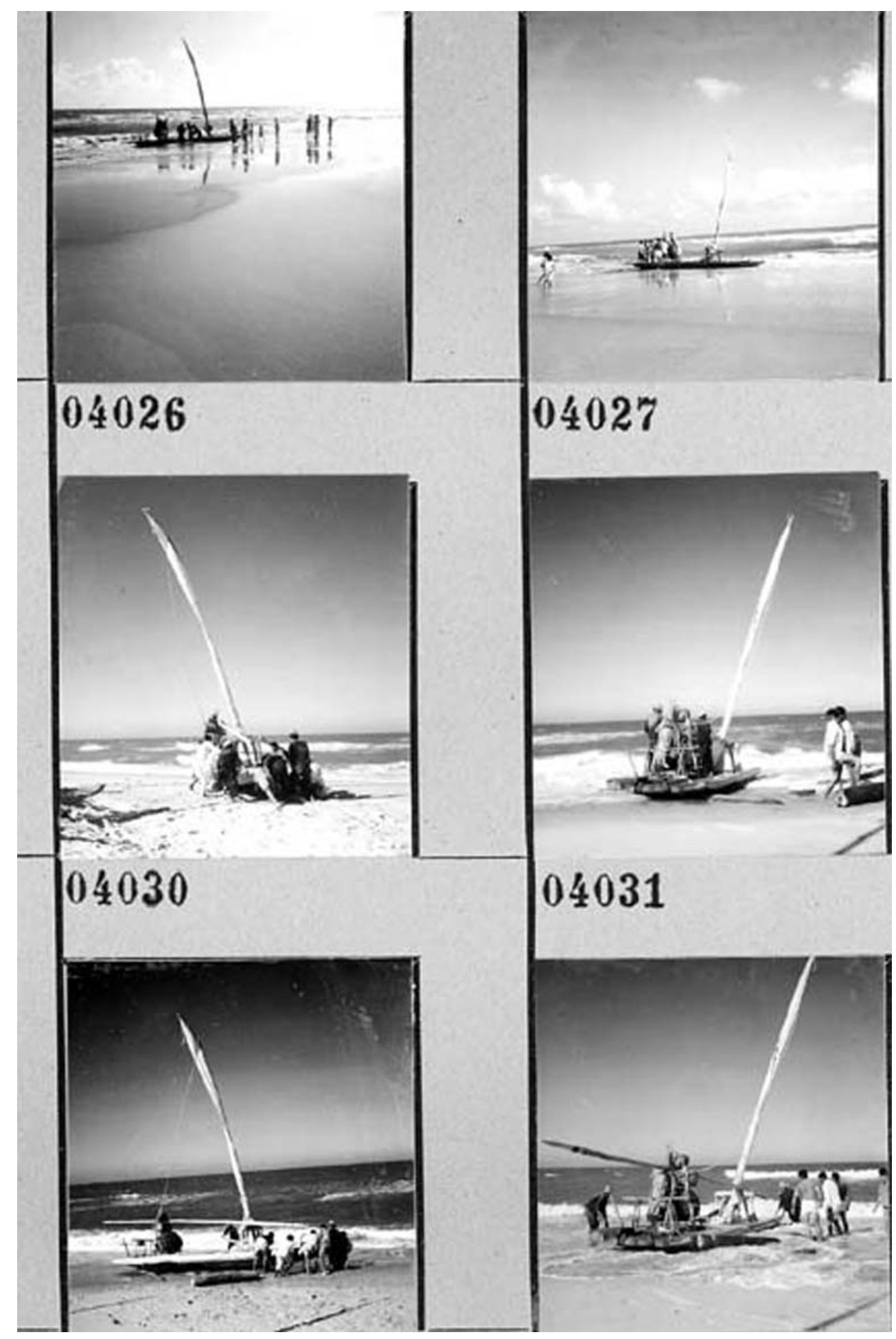

Annals of Museu Paulista.v. 13. n.2. Jul.- Dec. 2005. 


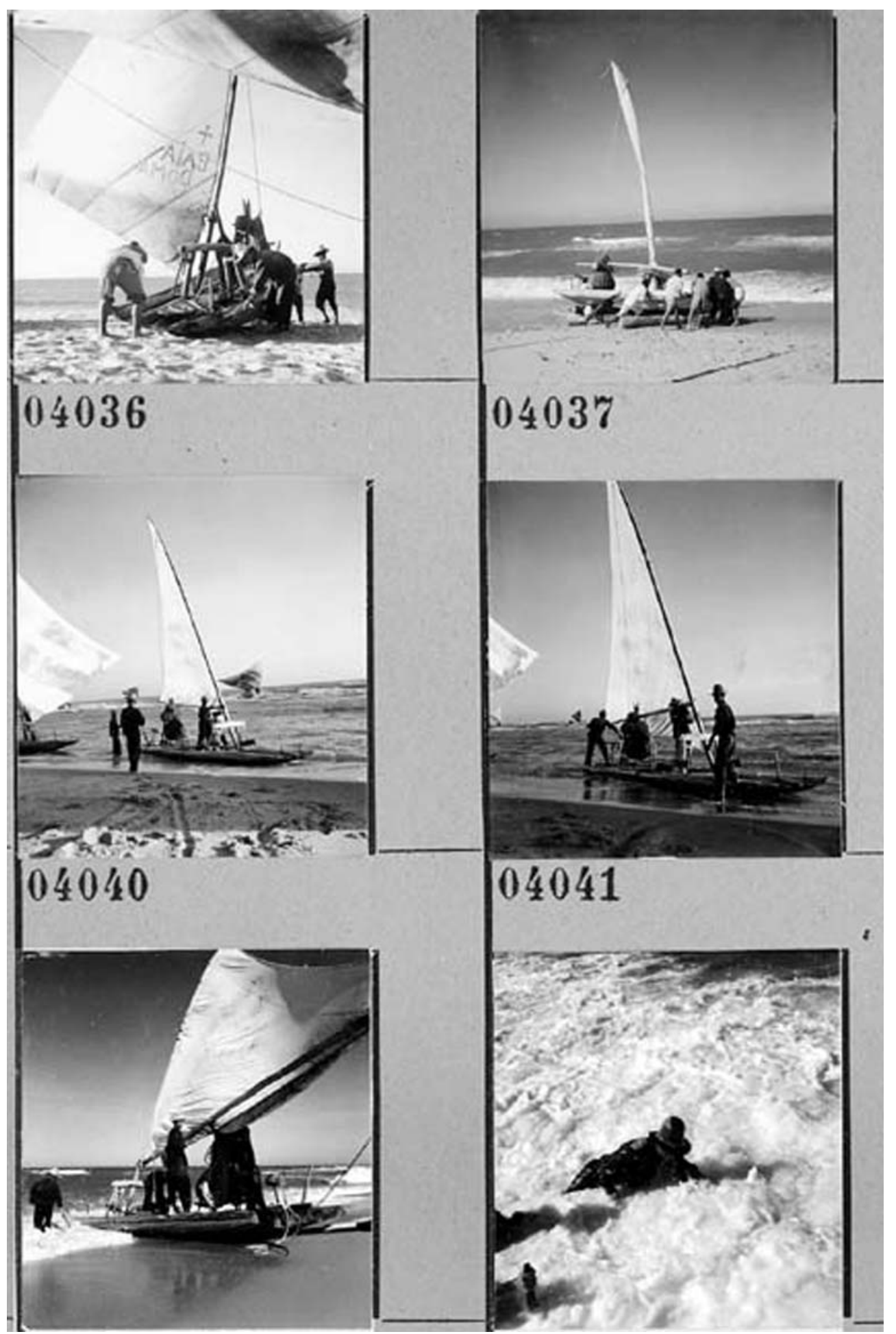

Figura 13 - Jangadas, Aquiraz/CE, c. 1950-1952. Fotografias de Marcel Gautherot. Acervo do Instituto Moreira Salles. 


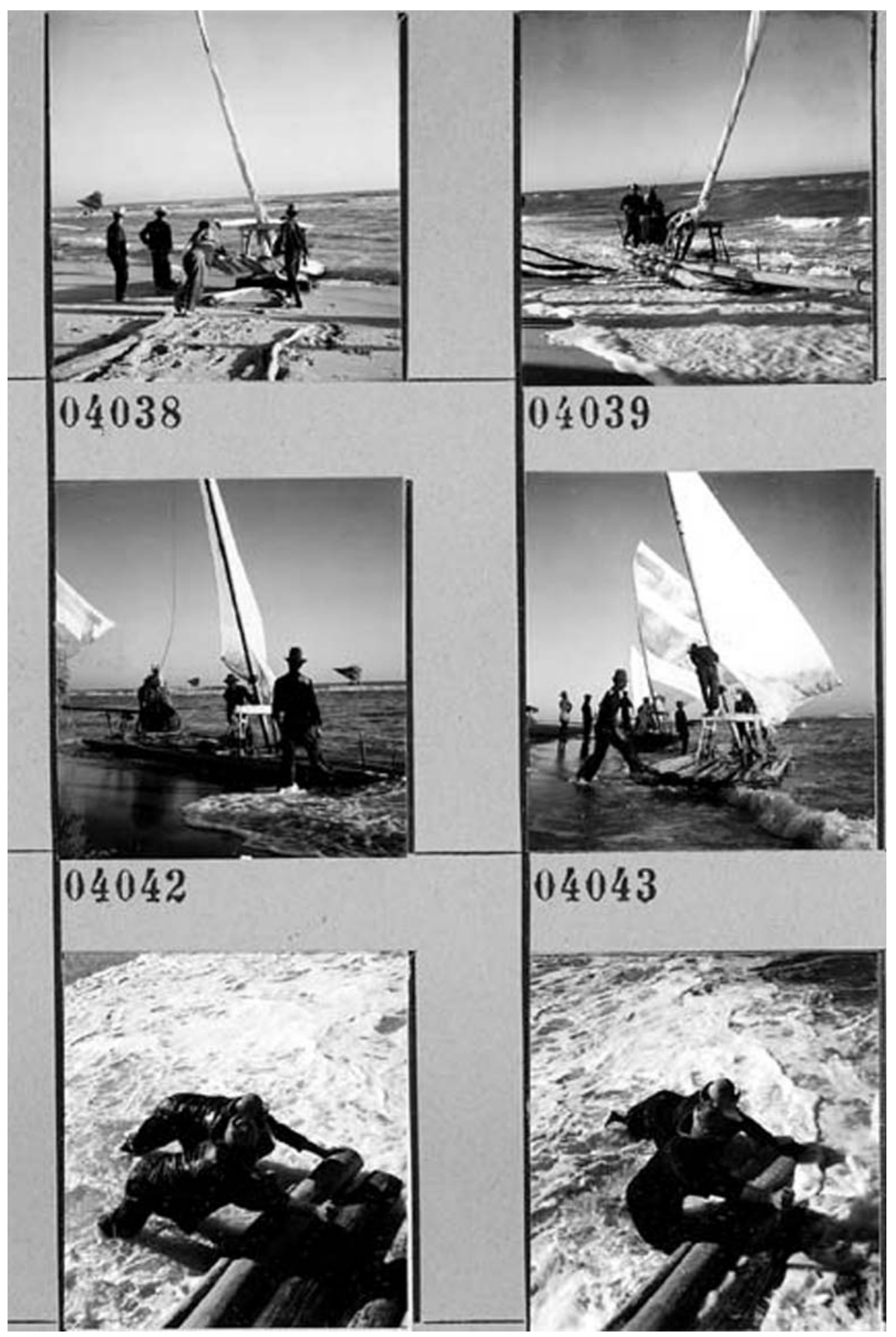




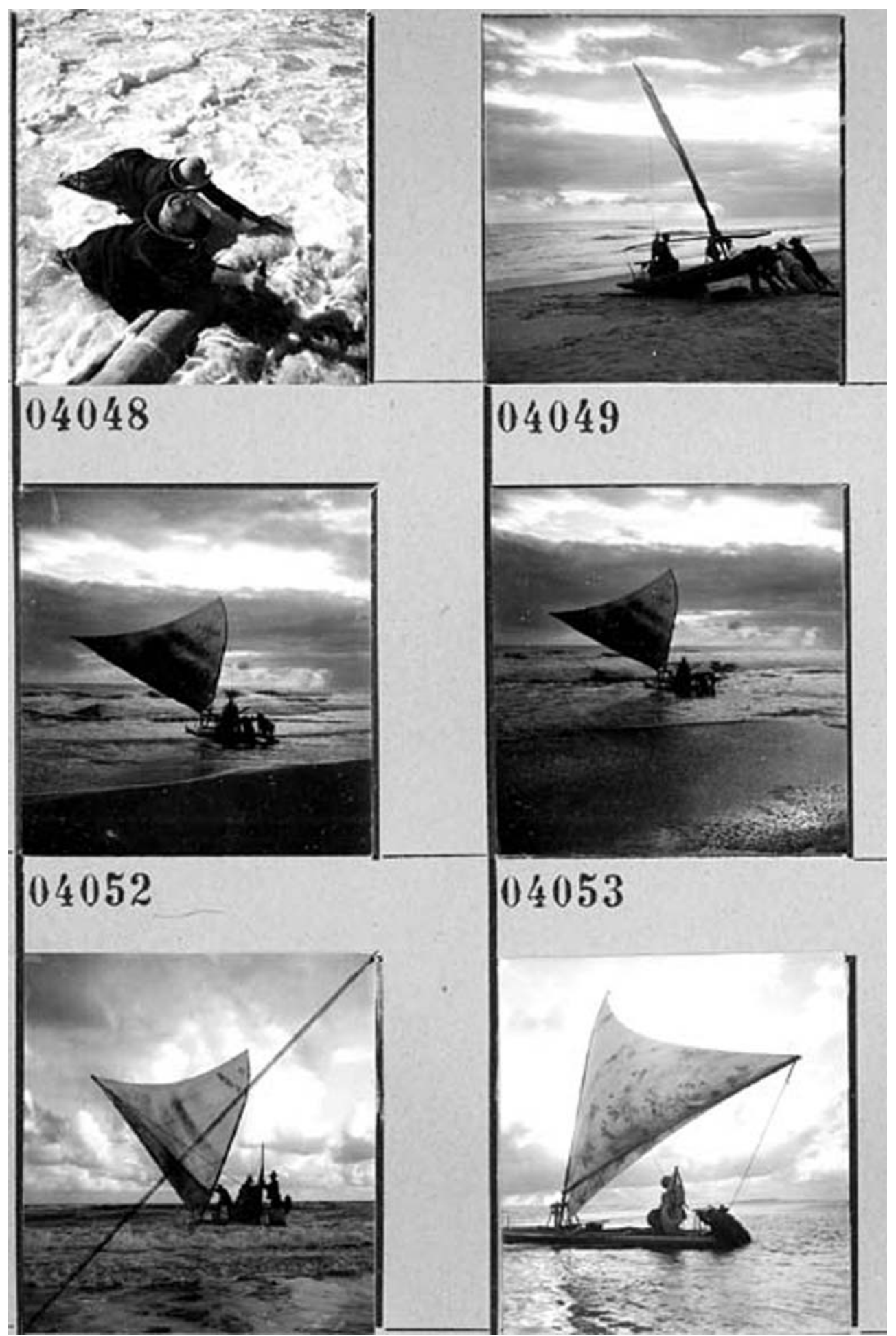

Figura 14 - Jangadas, Aquiraz/CE, c. 1950-1952. Fotografias de Marcel Gautherot. Acervo do Instituto Moreira Salles. 


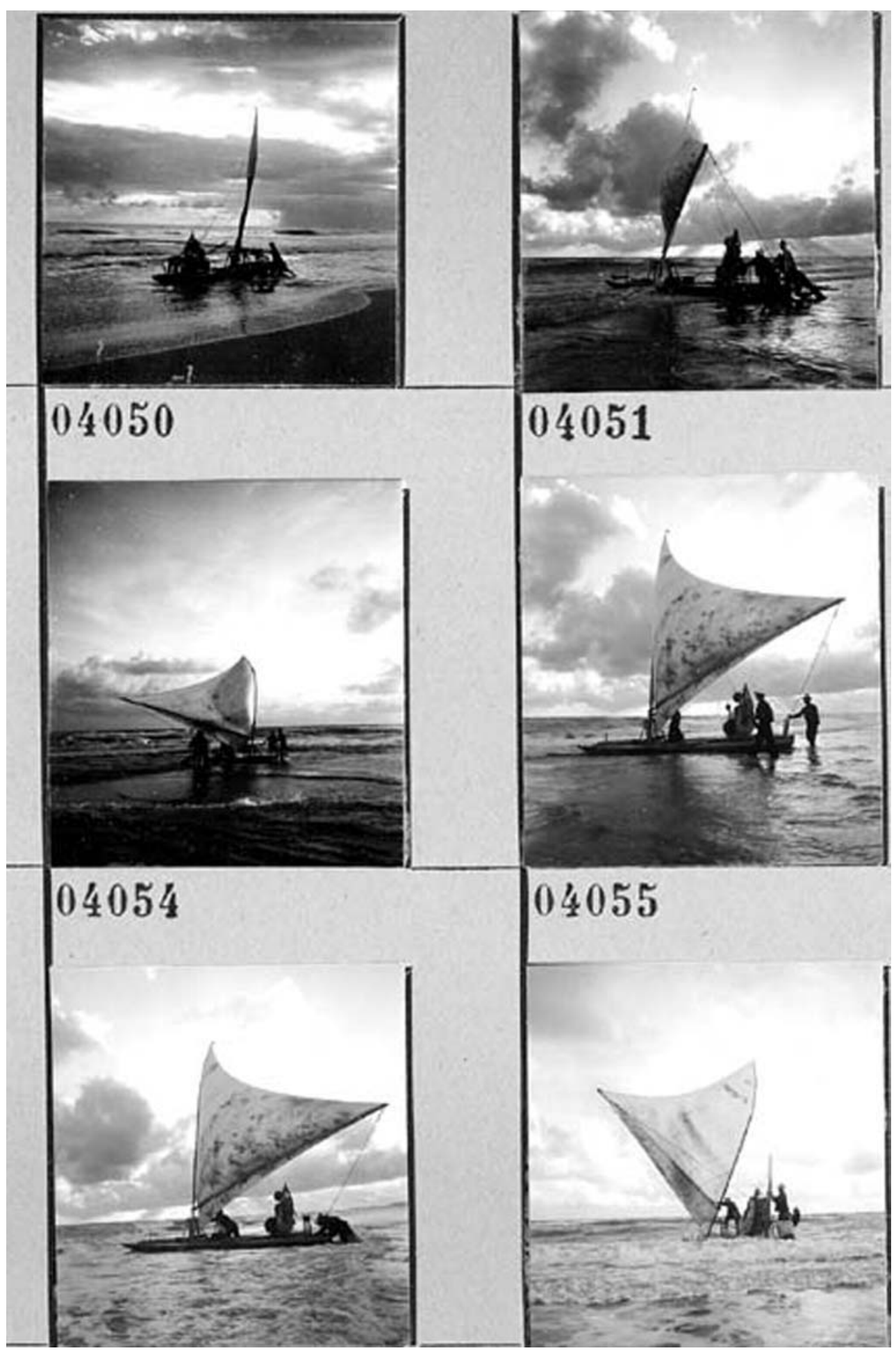

Annals of Museu Paulista.v. 13. n.2. Jul.- Dec. 2005. 


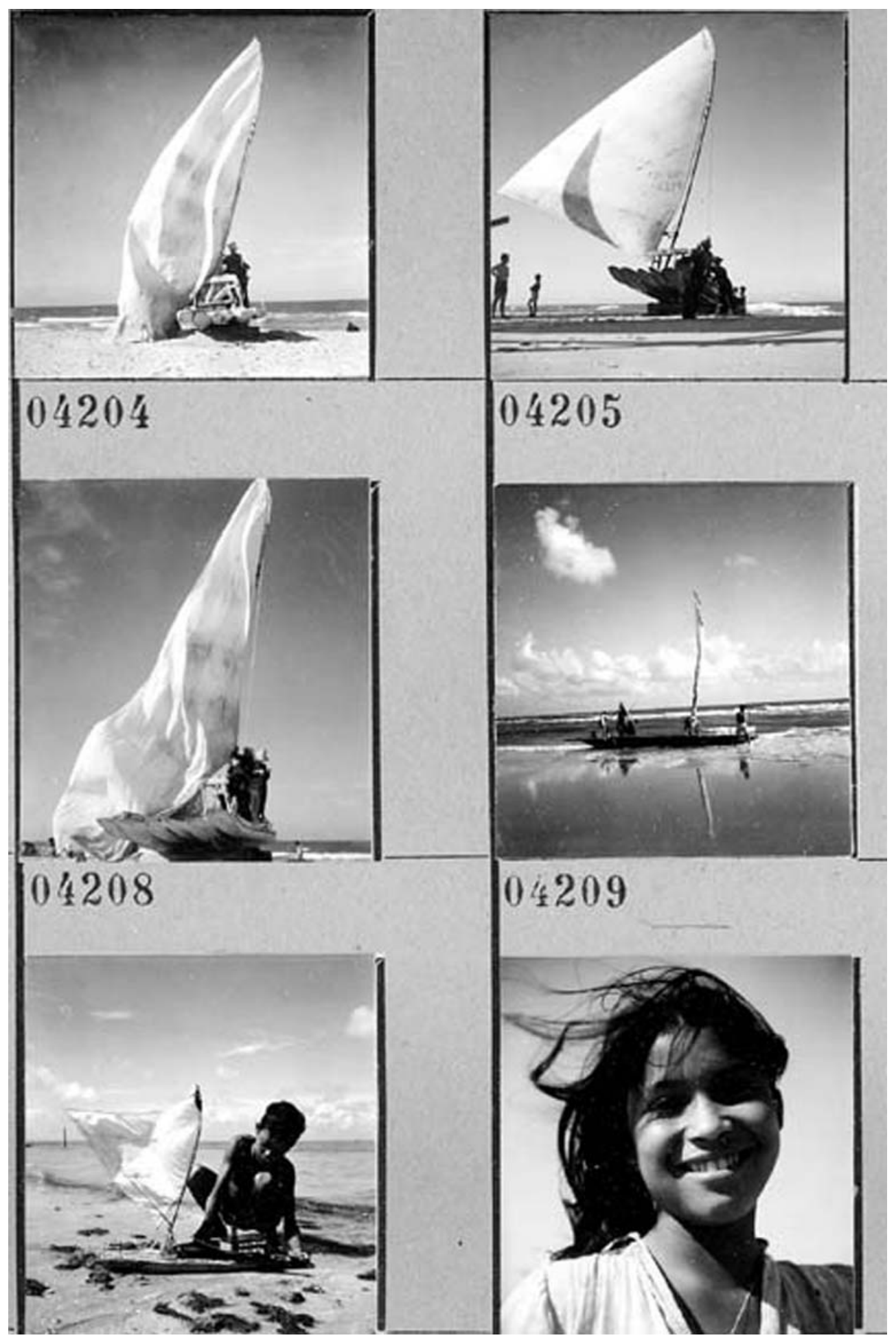

Figura 15 - Jangadas, Aquiraz/CE, c. 1950-1952. Fotografias de Marcel Gautherot. Acervo do Instituto Moreira Salles. 


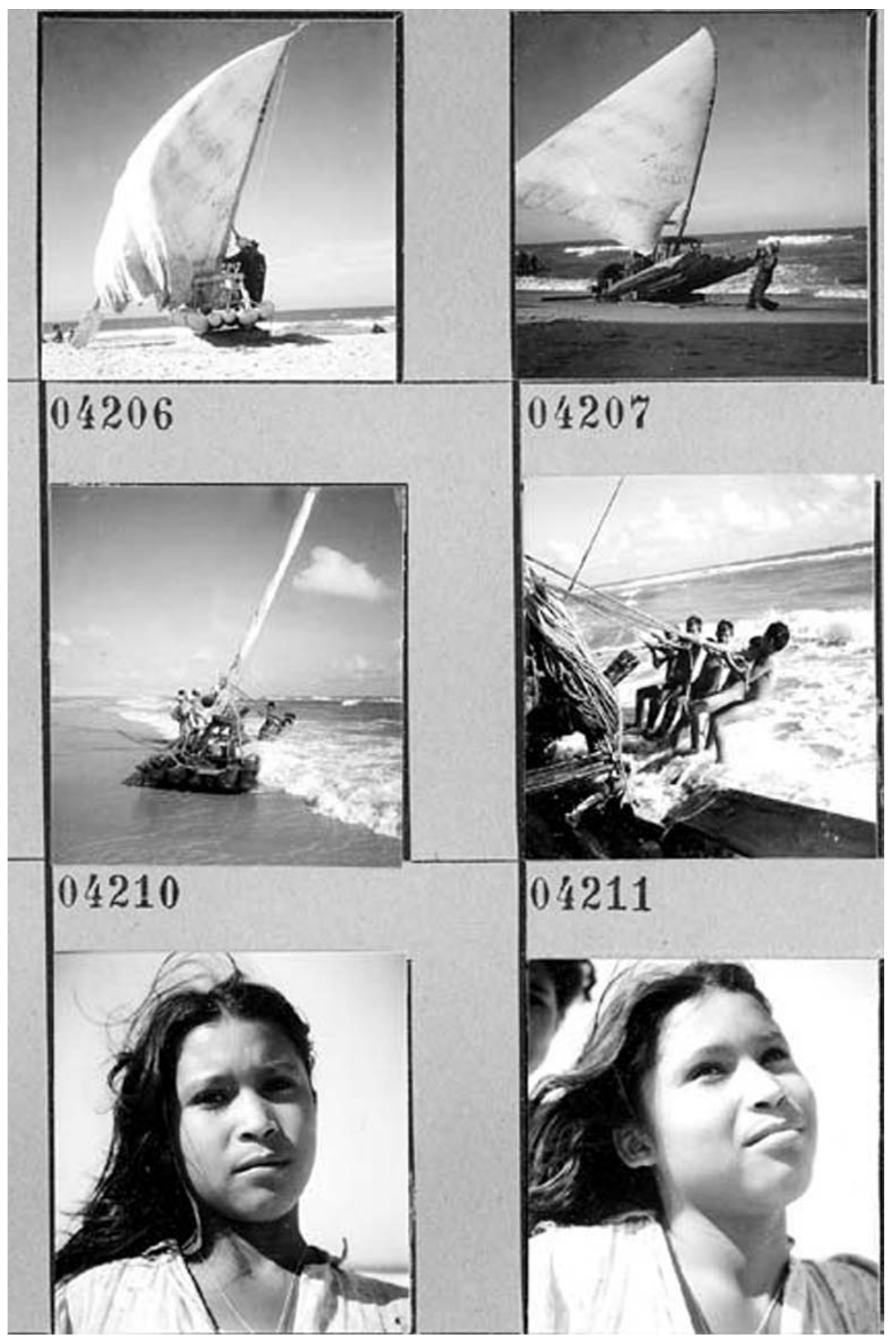

Annals of Museu Paulista.v. 13. n.2. Jul.- Dec. 2005. 


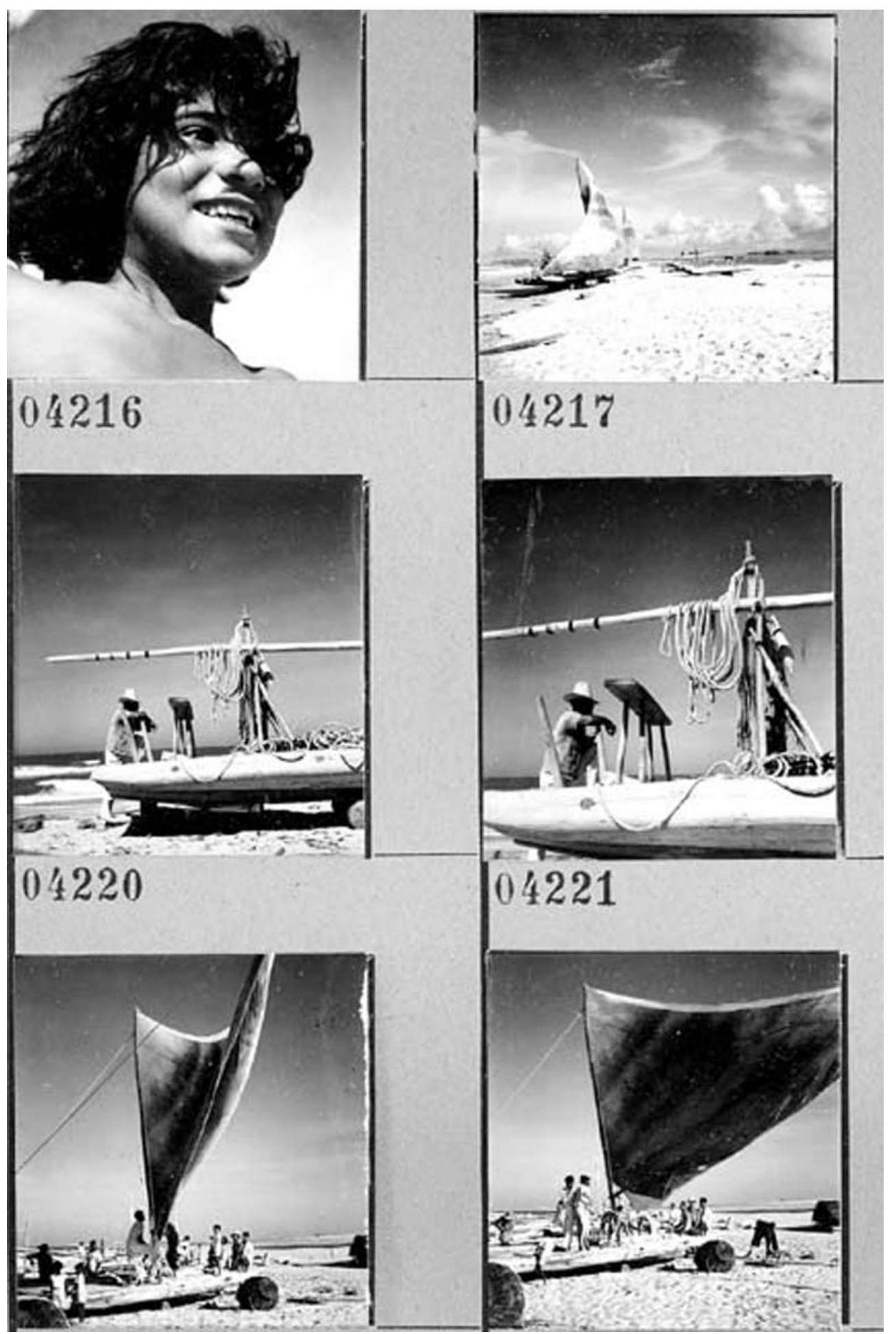

Figura 16 - Jangadas, Aquiraz/CE, c. 1950-1952. Fotografias de Marcel Gautherot. Acervo do Instituto Moreira Salles. 


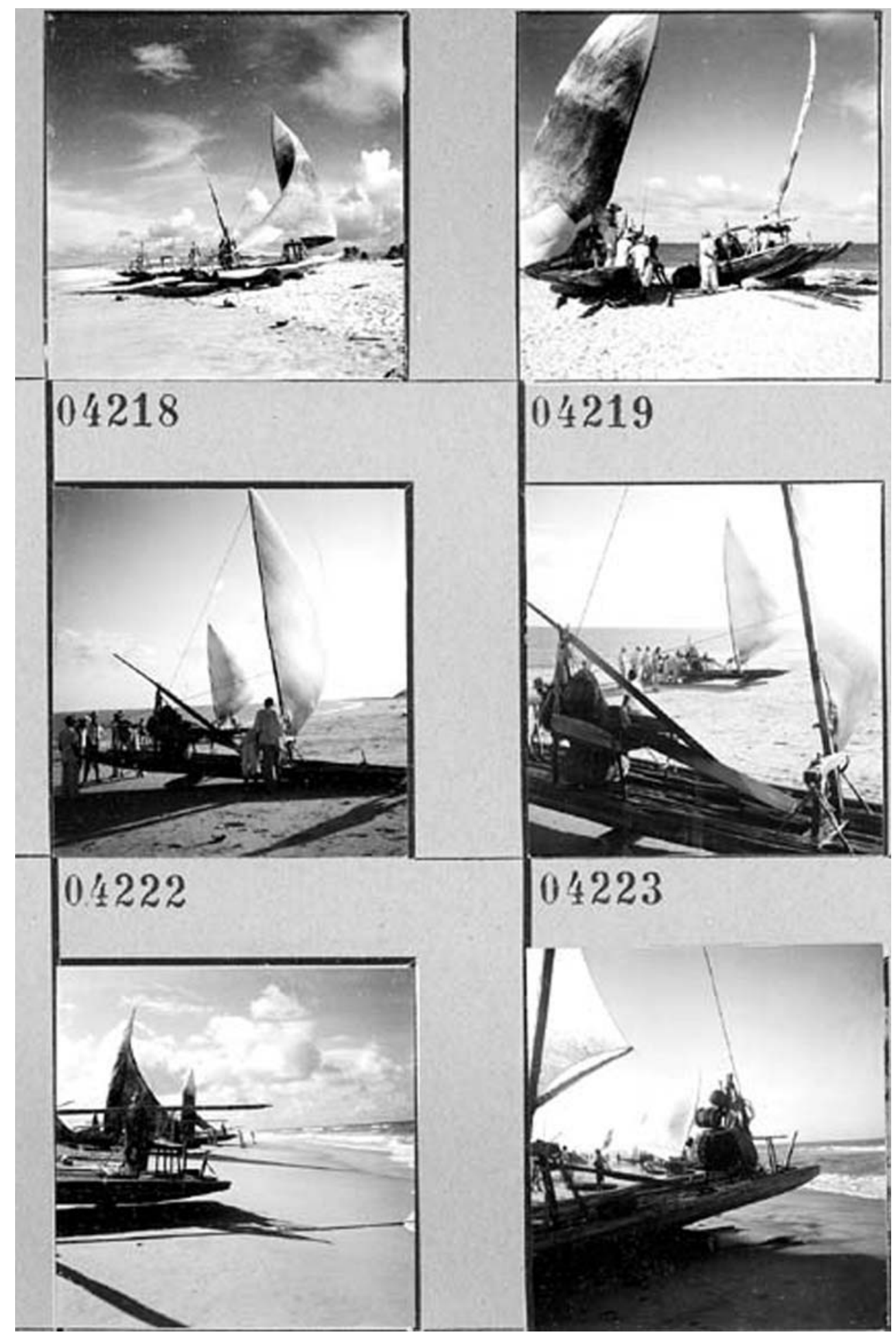




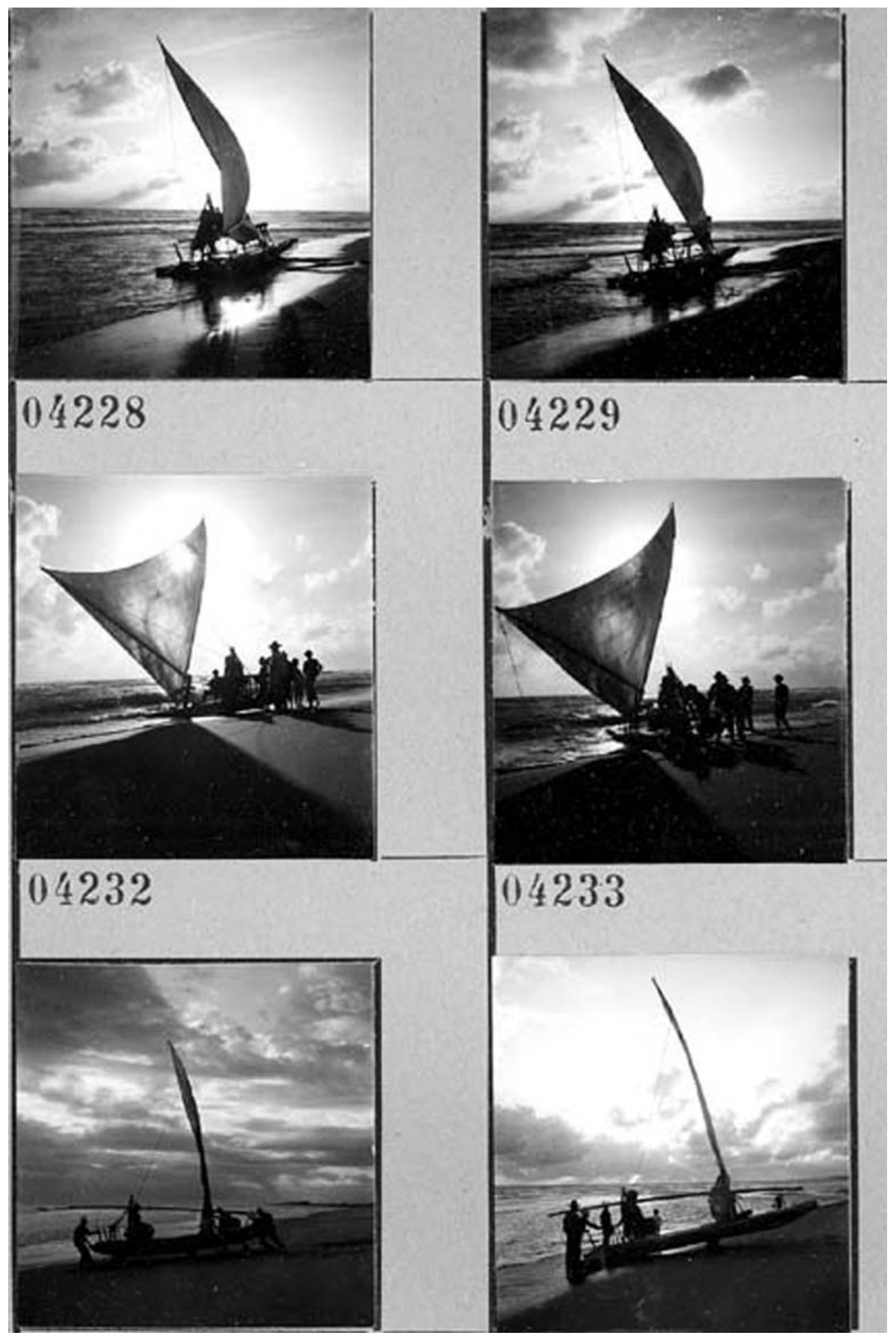

Figura 17 - Jangadas, Aquiraz/CE, c. 1950-1952. Fotografias de Marcel Gautherot. Acervo do Instituto Moreira Salles. 


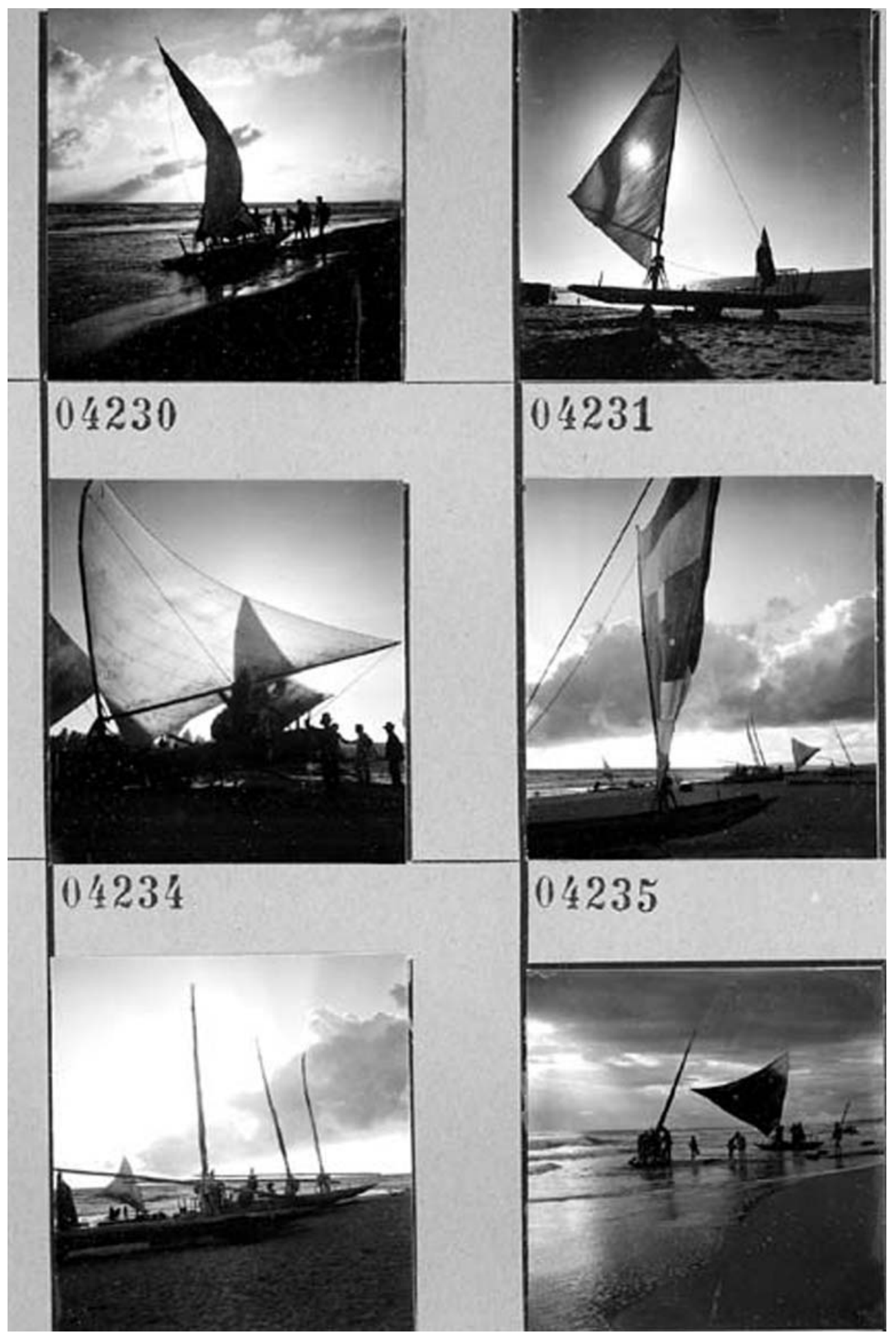

Annals of Museu Paulista.v. 13. n.2. Jul.- Dec. 2005. 
98. [Farm Security Administration] Survey Graphic, v. 28, n. 2, 1939. Apud LUGON, 2001, p. 274. aclamado nas disputas da literatura regionalista e moderna como o locus de "maior autenticidade" na definição emblemática da nação. Do Sul do país com expressivos contingentes de imigrantes europeus, principalmente italianos e alemães, guardam-se registros esparsos.

Dentro de cada Estado define séries temáticas. No conjunto do arquivo, destinguem-se quantitativamente as séries temáticas sobre a cultura popular. A apreciação das séries, concebidas desde o ato fotográfico, afirma o senso documentário do trabalho, a desconstrução de representações cristalizadas. As séries são, em geral, narrativas, como recorrentemente acontece na documentação etnográfica ou na fotorreportagem, partindo das tomadas gerais ao detalhe, no mais das vezes o portrait (Figuras 18-20). A ordem regular de registro-do geral para o particular e por vezes o inverso - permite comparativamente certos recortes temáticos, por exemplo, séries de retratos, explorados em livros e exposições. Diferentemente do ensaio American Faces ${ }^{98}$, de 1939, que mostra a diversidade dos tipos americanos, os brasileiros de Gautherot são quase sempre negros ou mestiços. $\bigcirc$ anonimato dos retratados sublinha, por operação simbólica, uma idéia genérica, uma identidade coletiva de povo brasileiro. As diferenças são localizadas, afirmam-se pelas representações do trabalho, das festas ou das paisagens. No registro de processos de trabalho, há uma atenção às suas diferentes etapas, aos instrumentos, à indumentária de quem produz. A câmera acompanha a seqüência demonstrativa dos fatos. Nas feiras (Figura 21), dentro de uma mesma lógica de localização, importa flagrar, no mesmo tempo, a diversidade, a descontinuidade dos motivos, dos produtos, percebidos, eles mesmos, na sua repetição, muitas vezes, como séries. A doca e o mercado, na série do Ver-o-Peso, em Belém do Pará (Figuras 22-24), explorados com recorrência nas séries fotográficas sobre o "Brasil característico", fornecem plasticamente visibilidade aos processos de circulação de gentes, de mercadorias, de informações, lugar privilegiado da vida social nessa capital amazônica.

Para além da dimensão relacional das imagens, a arquitetura fotográfica cuidada de Gautherot imprime um ritmo, uma dinâmica descritiva em cada quadro. Tal efeito calculado, sabemos, é difícil de ser realizado com o filme $6 \times 6$, quadrado, que ele utiliza. Enquanto o de $35 \mathrm{~mm}$, retangular, tem uma maior horizontalidade e portanto um movimento maior na leitura, $06 \times 6$ centraliza o objeto.

Há de se ressaltar ainda o grande conhecimento do fotógrafo sobre o trabalho no laboratório. Tal saber técnico certamente the permitia prever, desde o ato fotográfico, certas possibilidades expressivas a serem exploradas nos processos de revelação e reprodução da imagem.

Nas séries sobre as festas, as danças dramáticas, os ritos populares, perdem-se com freqüência, no aglomerado e nos movimentos, os nexos internos, a seqüência temporal do acontecimento (Figuras 25 e 26). Na fragmentação do exercício fotográfico, os motivos focados se relativizam, no jogo de imprevistos, diante das exigências de enquadramento, de tempo e de luz. Nessas composições, abre-se uma estreita circularidade entre os corpos vivos e as coisas, exigindo-se do observador uma atenção particular para desentranhar dessa 
trama formal, desse jogo de superfícies, a dimensão humana e a espessura histórica. Por vezes, o tratamento em profundidade reverte para uma relação bidimensional que abstrai o acontecimento e insiste na solução gráfica. A superposição dos corpos, em algumas imagens, aparece quase como um trabalho de fotomontagem, distinguindo-se os planos, evitando-se a desordem da tensão (Figuras 27 e 28). Nos aglomerados, adensa-se o sentido da cena, que em outros momentos se decompõe na aproximação das figuras, no silêncio do portrait, do detalhe do rosto que joga o olhar para longe da câmera, eternizando a pessoa.

No arquivo organizado por Gautherot, atravessando a classificação temática, há séries numéricas seqüenciais, por vezes intervaladas. As várias viagens fotográficas que realizou, ainda não completamente mapeadas, parecem determinar algumas dessas descontinuidades. Nesse sentido, é possível perceber séries numeradas situadas em Estados diferentes. A numeração crescente é insuficiente, porém, para estabelecer uma ordem rigorosamente cronológica de produção99. Não há legendas específicas para cada negativo.

Essa atenção ainda que não especializada na conservação e identificação dos negativos e contatos é reveladora do modo pelo qual Gautherot usava sua produção e valorava o seu acervo. A acumulação dos negativos, imobilizando-os no mercado fotográfico, sustenta seu interesse de preservar uma totalidade, pressuposto à monumentalização de sua obra.

Os contatos têm nessa sua estratégia um lugar especial como reprodução positiva, corrigida dos negativos. Do ponto de vista técnico e narrativo, são provas de sua interpretação, marca de autenticidade ${ }^{100}$. Definemse como objetos fotográficos indiciais e ao mesmo tempo materializam e miniaturizam a leitura completa da coleção. Esse exercício cuidado de autoria articula a produção do acervo ao seu próprio reconhecimento como fotógrafo. A inscrição biográfica atravessa a ordem interna do arquivo. Gautherot mostra e guarda nas séries compiladas seu próprio trajeto, senso fundamental da sua trajetória, sua mobilidade no espaço, no tempo, na hierarquia social.

Ainda em vida, o fotógrafo tentou vender seu acervo a instituições públicas: ao IPHAN, à Funarte, ao Museu de Folclore Edison Carneiro, no Rio de Janeiro. Não houve acordos. Depois de sua morte, em 1996, seu único filho chegou a pensar em fundar uma espécie de associação de amigos, com o intuito de cuidar do acervo. Em 1998, o Instituto Moreira Salles o adquiriu, incorporando-o ao conjunto das suas coleções fotográficas ${ }^{101}$.

Nesse processo, o acervo pessoal fotográfico - como conjunto documental produzido e acumulado por Gautherot ao longo de sua vida, pautado por uma economia e por usos específicos das imagens - redefine-se como coleção institucional, em que ganha relevo sua qualidade estética ${ }^{102}$.

Cabe esclarecer que, na sua política de aquisição, o IMS busca coleções ou arquivos autorais completos. Na obra de fotógrafo, ressalta Sérgio Burgi, contam as "características mais orgânicas do seu desenvolvimento profissional". Respeita-se a sua ordem original e a sua proveniência.
99. Sérgio Burgi explica que a equipe do IMS "está fechando a ordem seqüencial dos negativos $\mathrm{e}$ fazendo cruzamento com as divisões temáticas. Aparecem algumas questões que ainda não estão claras, as questões das viagens de volta aos lugares que normalmente estão expressas por séries mais adiantadas. Em alguns momentos você tem séries que estão situadas em vários estados diferentes" (Entrevista em 17/5/2004).

100. Seguindo Moulin a idéia de autenticidade, no mercado e nos saberes autorizados da arte, vincula-se à verdadeira autoria enquanto a de originalidade liga-se à obra única. Cf. MOULIN, 1978, p. 241-258.

101. A documentação sobre a compra do acervo fotográfico de Gautherot não está aberta à consulta pública. É certo que as negociações em torno de cada coleção guardam especificidades. Os interesses circunstanciais de colecionadores, as expertises, os leilões de arte são referências na produção de valor.

102. Coleção é aqui uma categoria utilizada pela instituição para designar a proveniência dos arquivos ou séries fotográficas no momento de aquisição. 


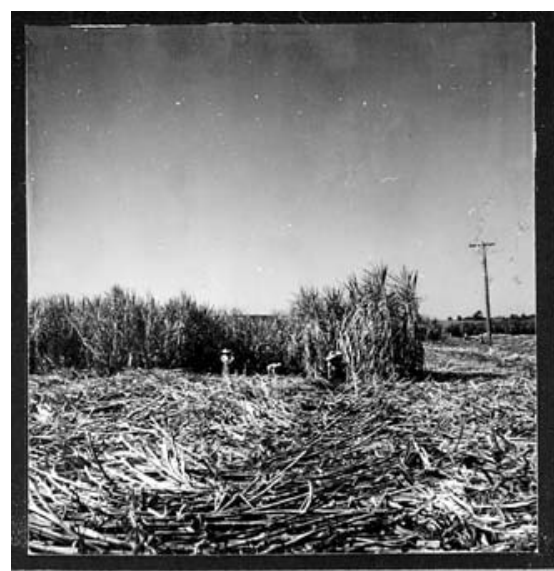

09760

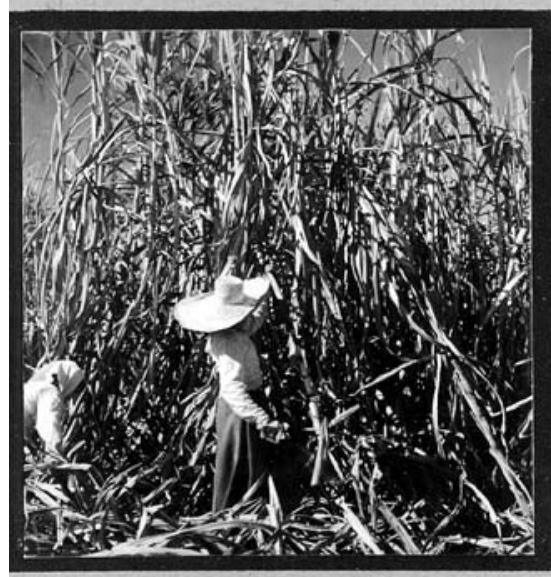

09764

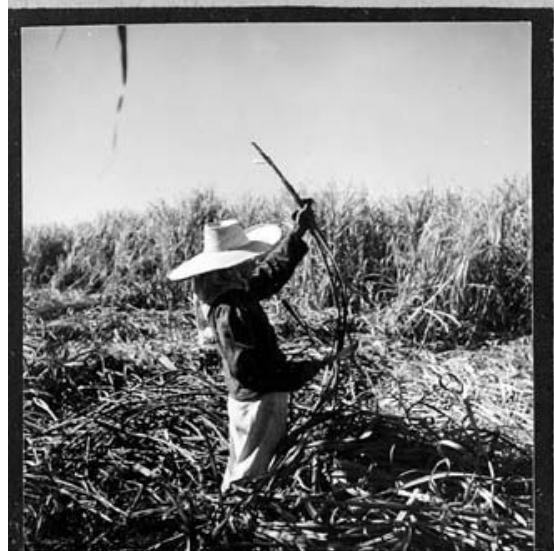

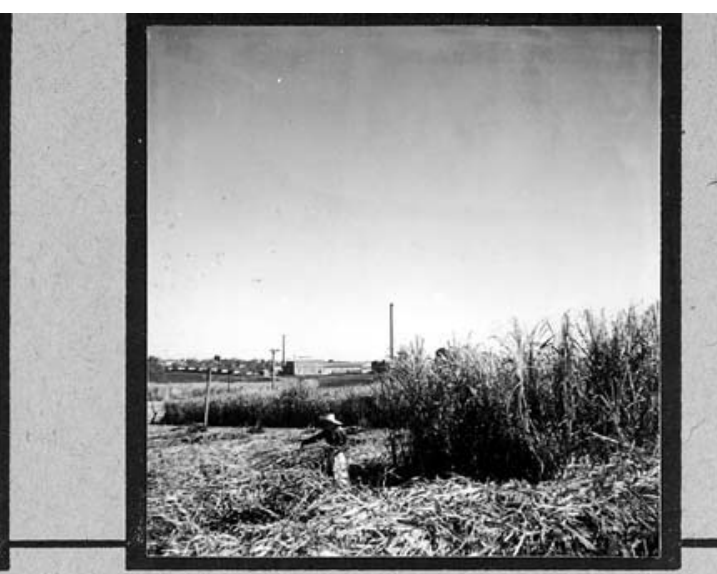

09761

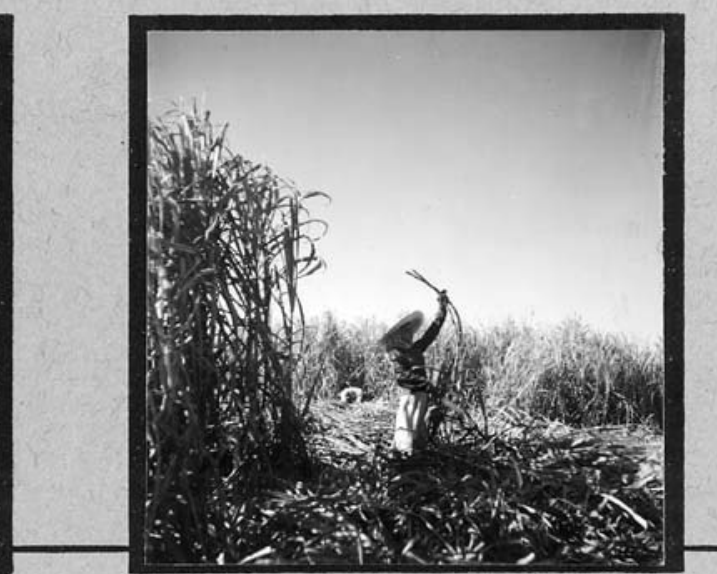

09765

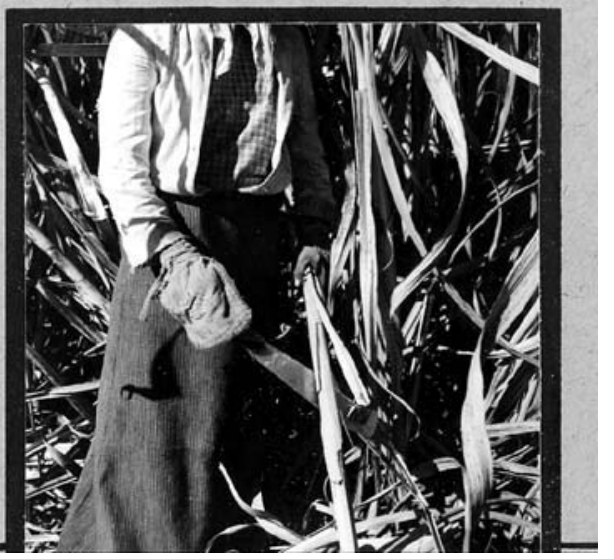

Figura 18 - Corte da cana-de-açúcar, PE, c. 1952-1955. Fotografias de Marcel Gautherot. Acervo do Instituto Moreira Salles. 


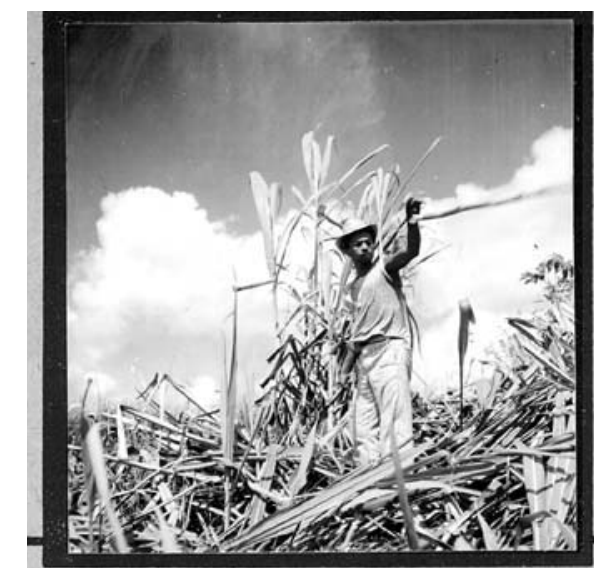

09762

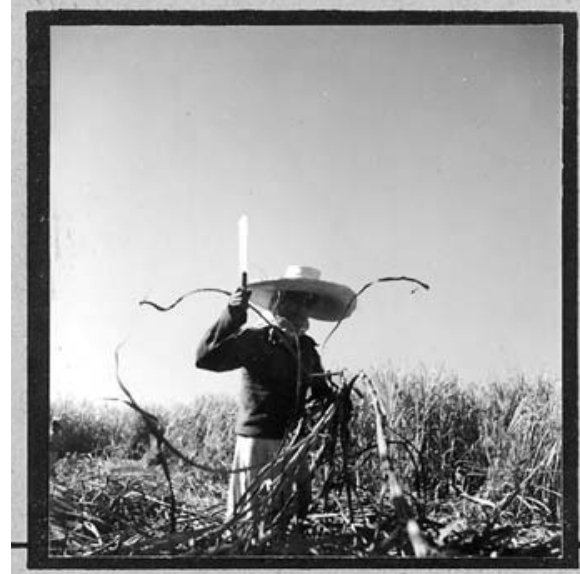

09766

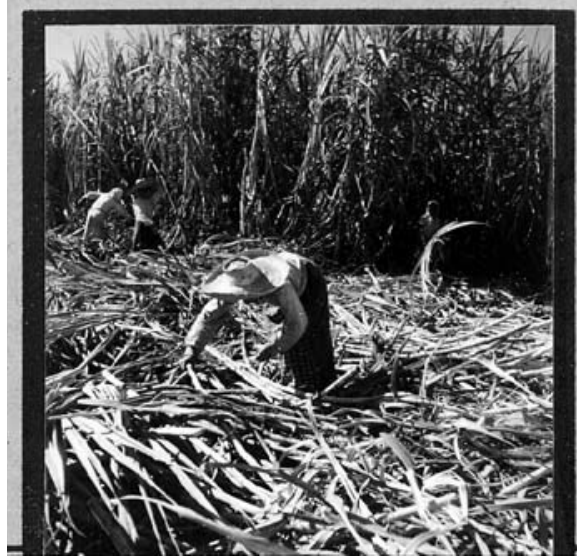

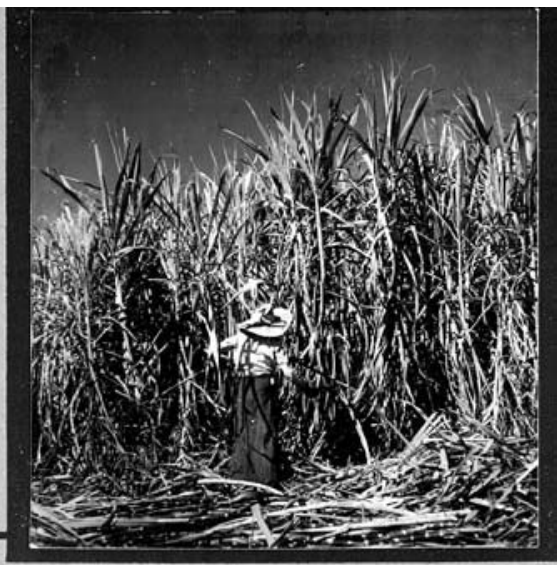

09763

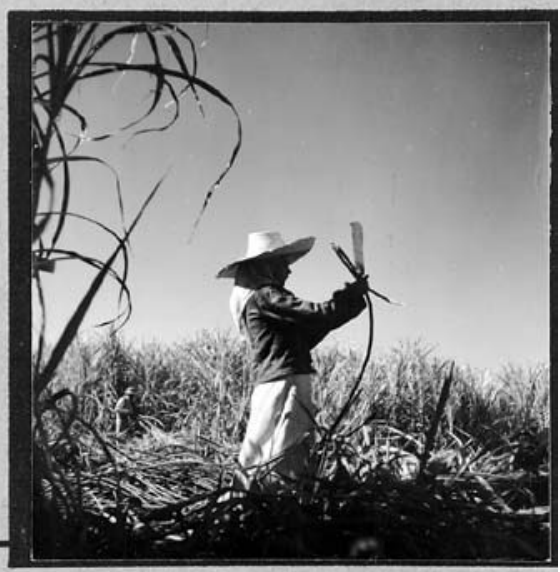

09767

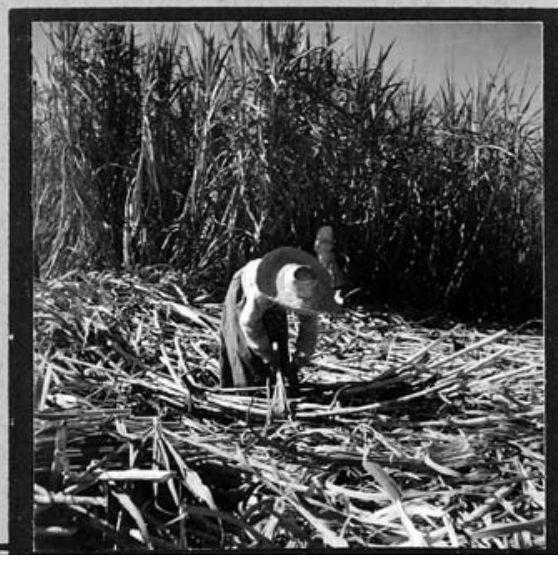



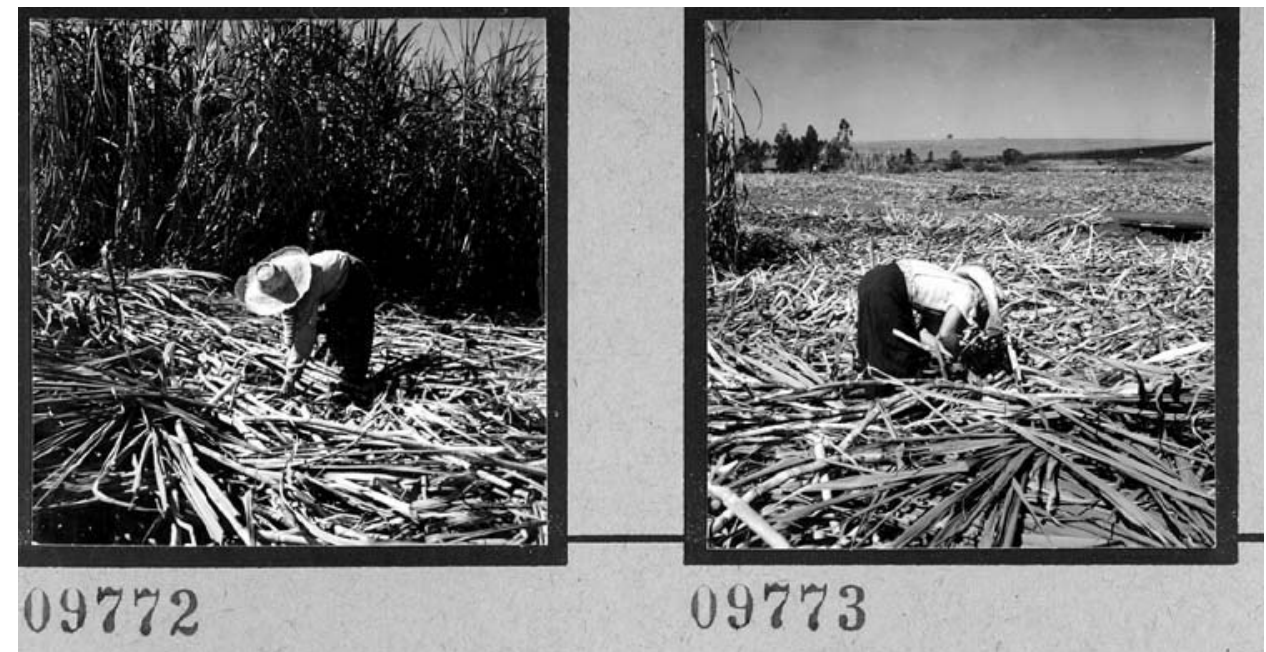

09773
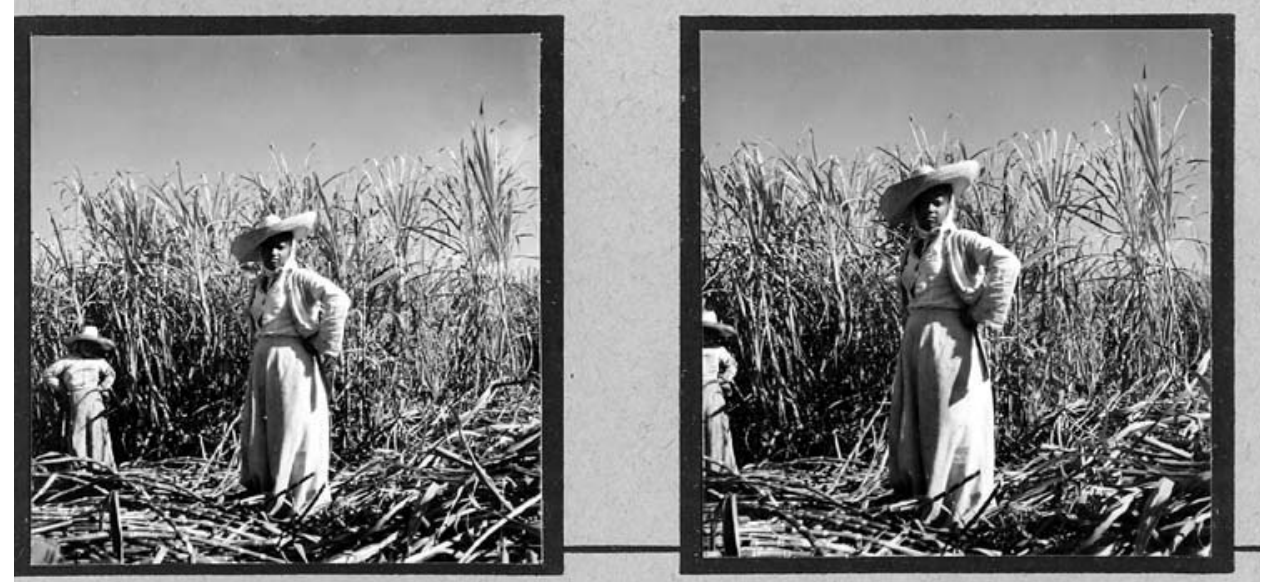

09776

09777
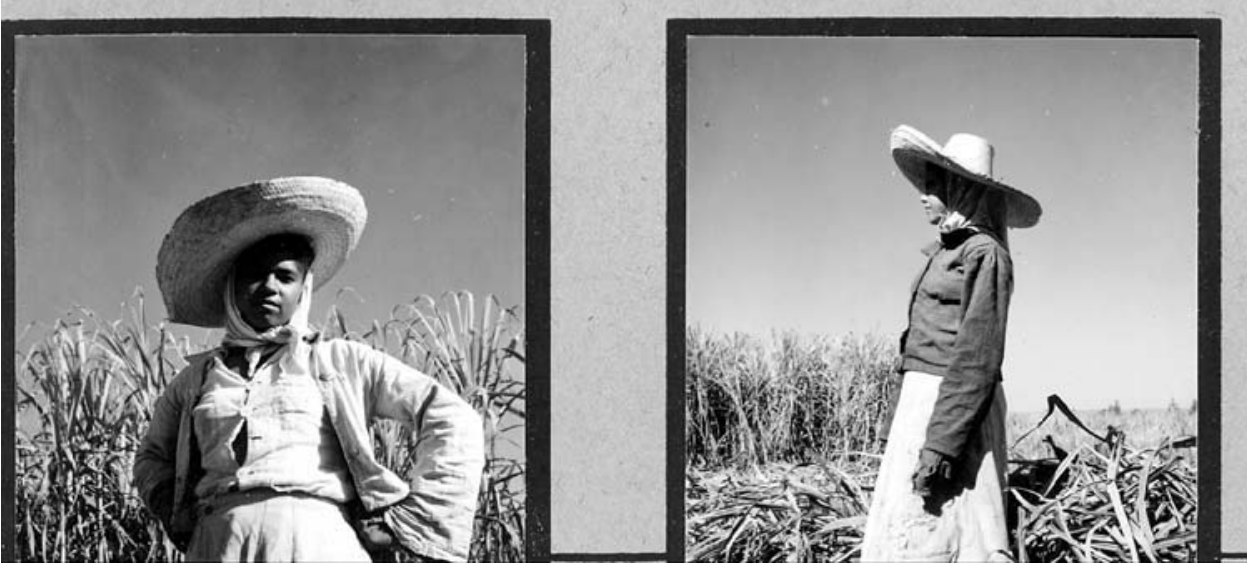

Figura 19 - Corte da cana-de-açúcar, PE, c. 1952-1955. Fotografias de Marcel Gautherot. Acervo do Instituto Moreira Salles. 

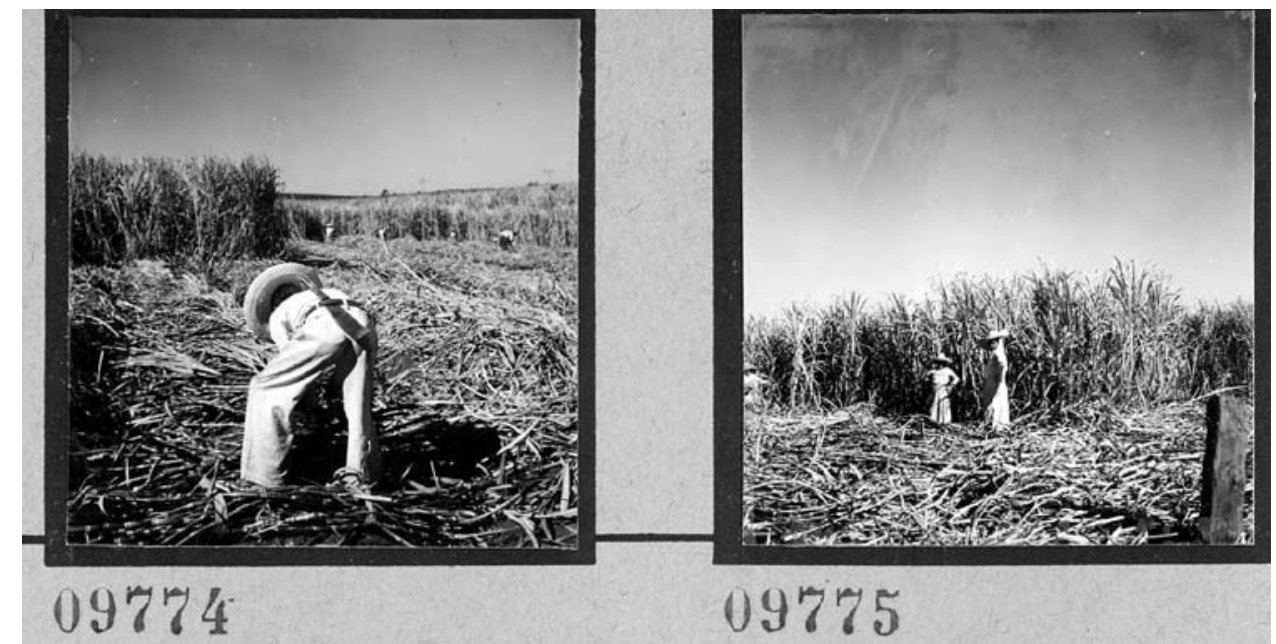

09775
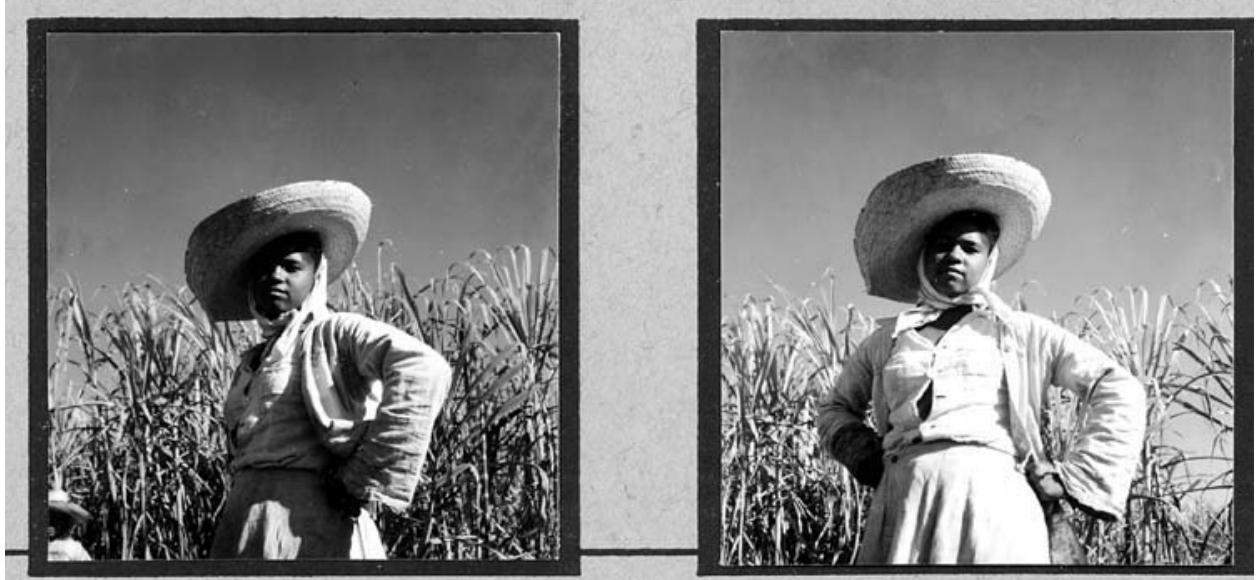

09778

09779
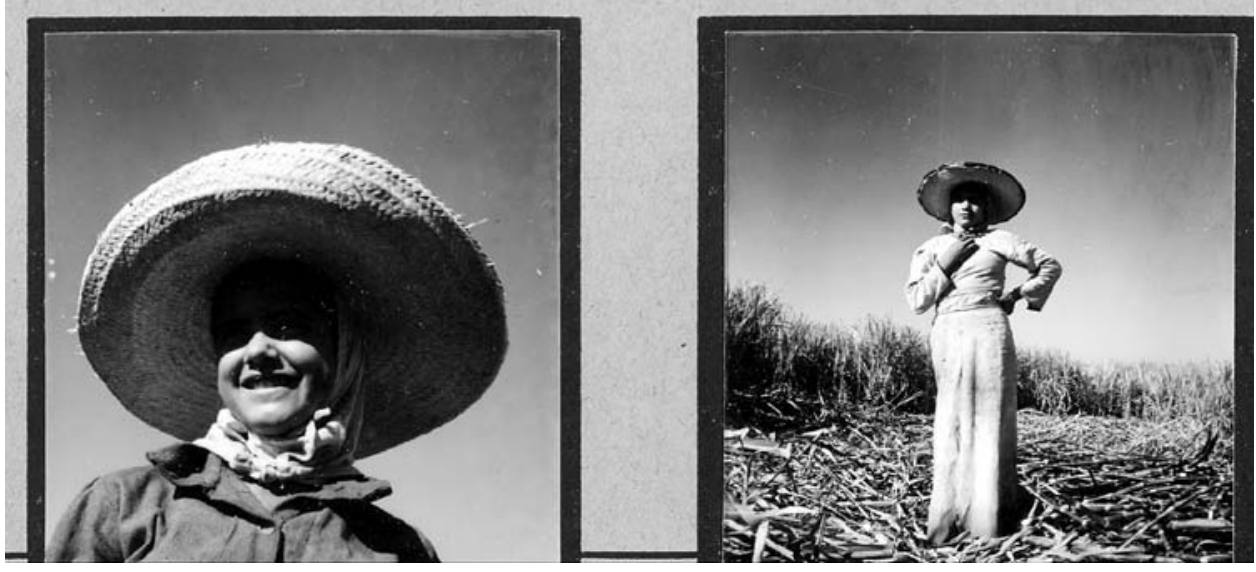

Annals of Museu Paulista.v. 13. n.2. Jul.- Dec. 2005. 

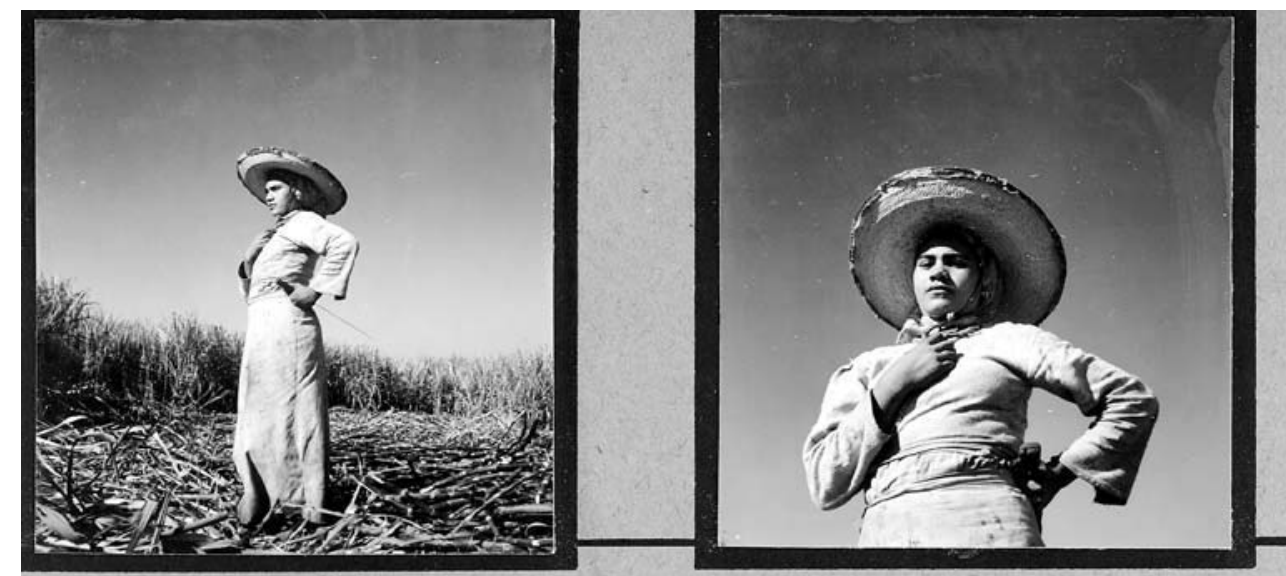

09784

09785

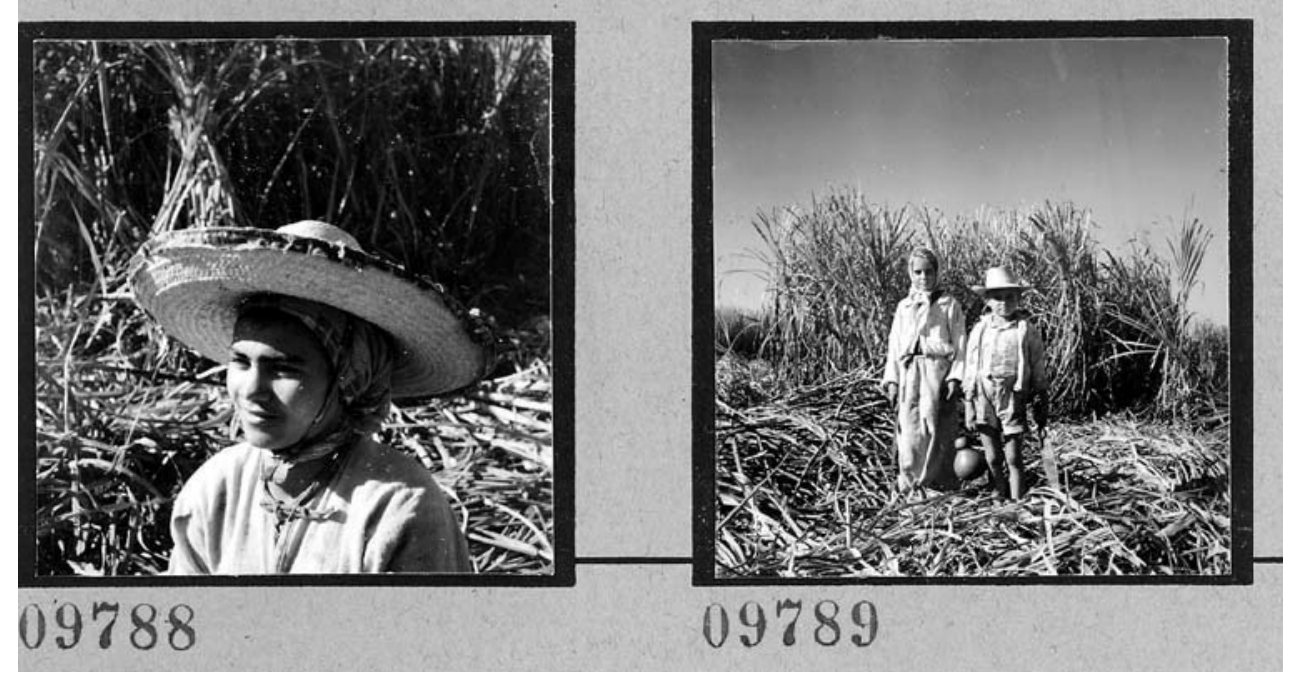

Figura 20 - Corte da cana-de-açúcar, PE, c. 1952-1955. Fotografias de Marcel Gautherot. Acervo do Instituto Moreira Salles.

Essa transferência do privado para o público requalifica o acervo do ponto de vista material e simbólico. Redefinem-se modos de preservação e conservação, reprodução e circulação de imagens. No caso, a instituição compradora procedeu ao inventário, à higienização e à estabilidade química dos originais (alguns negativos têm problemas de deterioração da base plástica ou da base de acetato celulose), que estão sendo digitalizados.

No tratamento e na difusão da coleção estão em foco a produção e a reprodução da notoriedade do fotógrafo e do próprio valor da coleção, promovendo no mercado de arte e de bens patrimoniais também a instituição que coleciona. $\bigcirc$ deslocamento para a reserva técnica, a limitação de oferta, o controle sobre o uso da coleção revalida o sentido da fetichização do único 


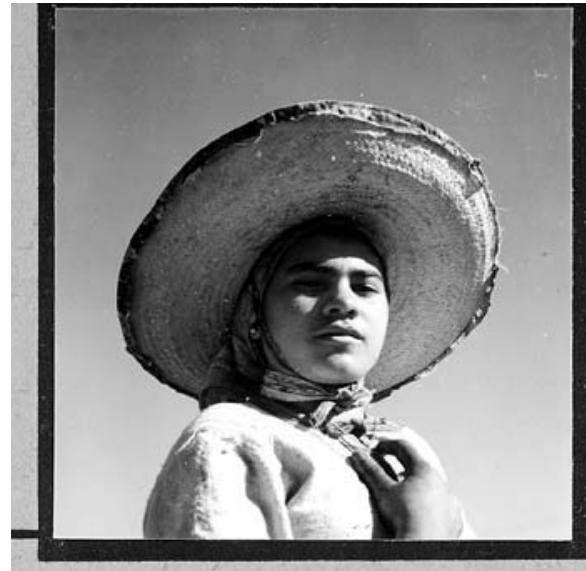

09786

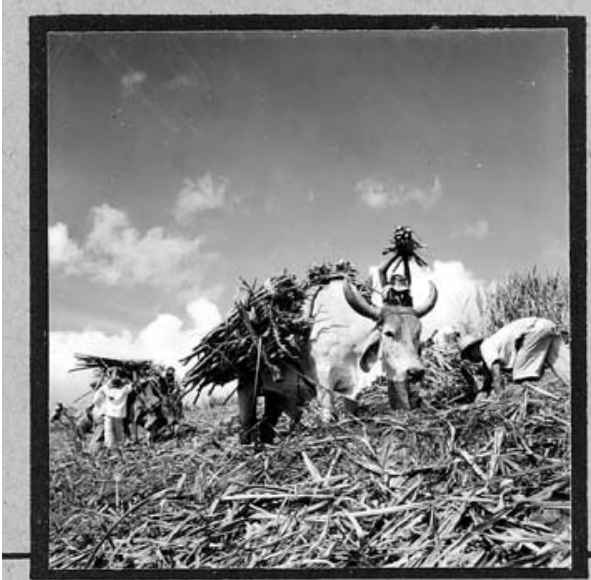

09790
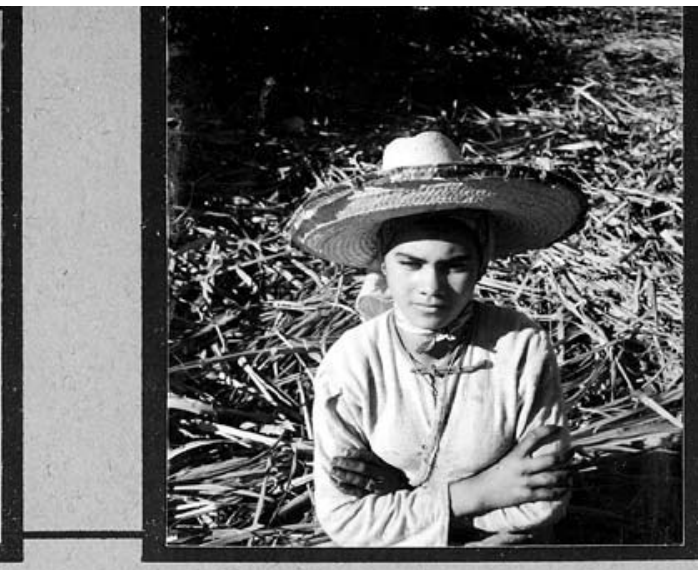

09787
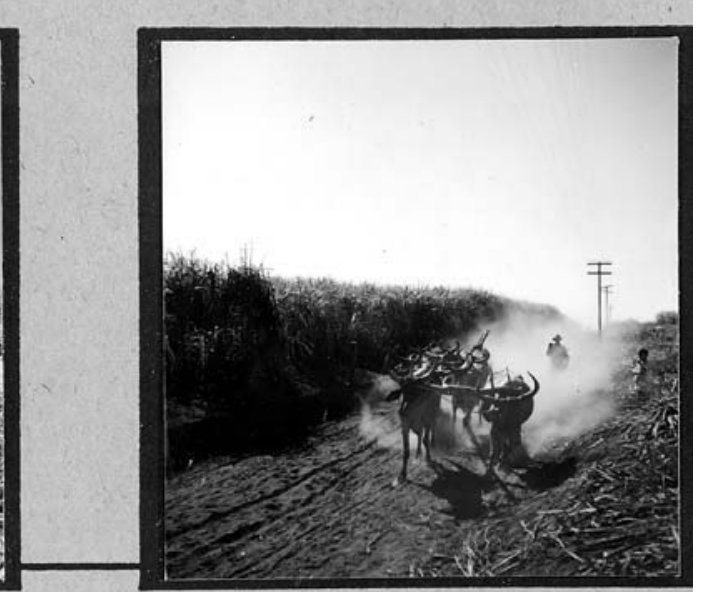

09791
103. É bom frisar que a atenção à raridade fotográfica, por parte desse mercado, vai a contrasenso da criação artística contemporânea que busca o múltiplo, o suporte efêmero, as instalações e as performances, a não produção de objetos definitivos.

104. MARESCA, 1995, p. 57-59.

105. Rouillé chama a atenção para esses deslocamentos da fotografia do domínio da curiosidade para o da utilidade (em que as imagens não são contempladas, mas consultadas) e o da estética. Cf. ROUILLÉ, 2005.

e suas extensões controladas que instruem dominantemente os interesses no mercado contemporâneo das coleções fotográficas ${ }^{103}$.

Essa raridade cultivada, no entanto, como bem observa Maresca ${ }^{104}$, aproxima-se menos daquela contemplada nos objetos artísticos e mais daquela atribuída a objetos etnográficos que entram em museus, ao termo de uma dupla operação de tempo: "de início, a sua profusão se reduz porque se degradam rapidamente e são menos bem conservados que a obra de arte; em seguida, à medida que eles perdem sua funcionalidade primeira prestam-se mais largamente à contemplação do esteta".

Como nos objetos etnográficos, a raridade na fotografia alimenta intimamente as práticas seletivas das artes do múltiplo. Distinguindo-se das imagens em série, de multiplicação do idêntico, vocação da reprodutibilidade técnica, a produção fotográfica limitada pode tornar-se significante no plano estético pela sua desfuncionalidade, rutura do seu senso corrente ${ }^{105}$. A validação 

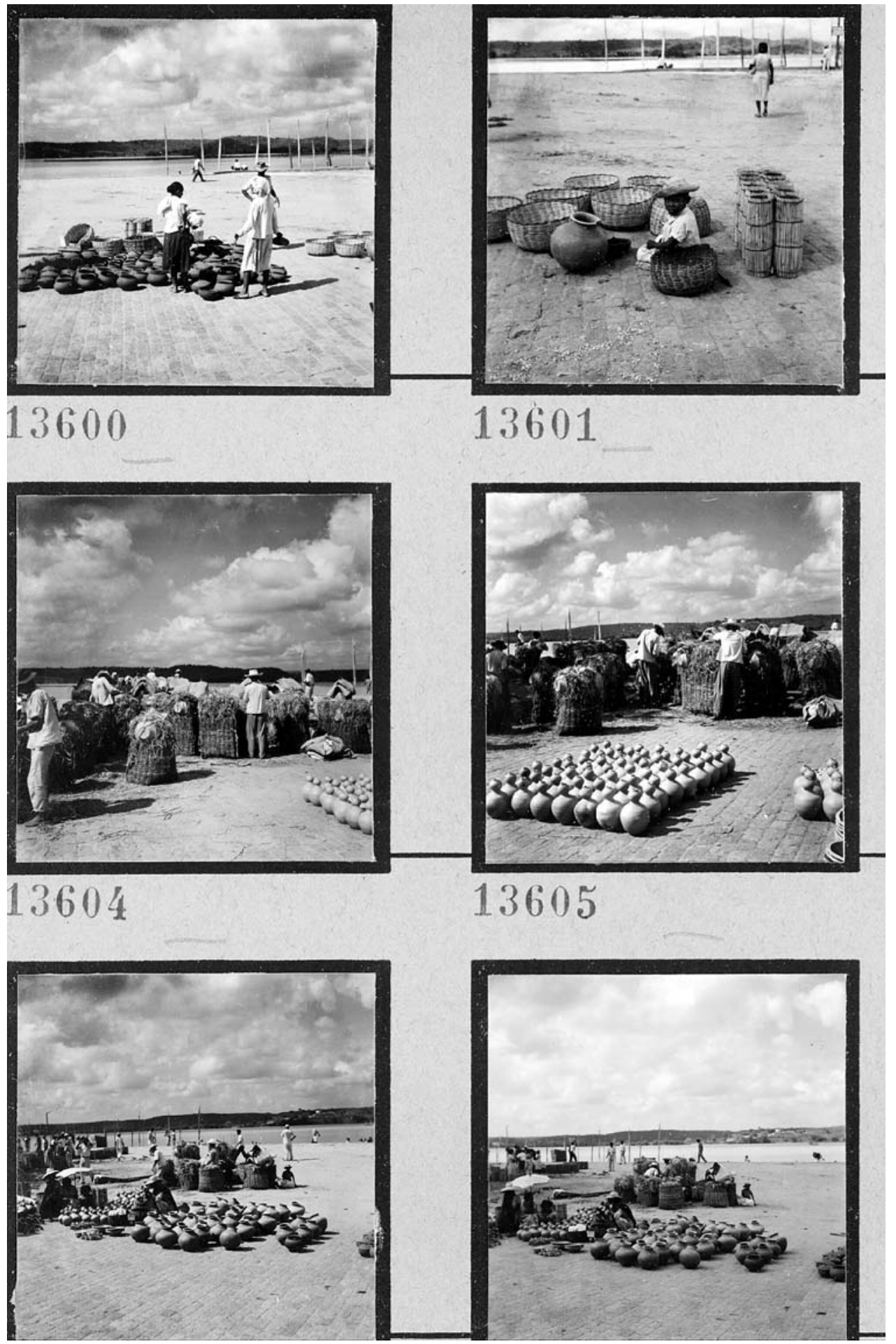

Figura 21 - Feira, Penedo/AL. Fotografias de Marcel Gautherot. Acervo do Instituto Moreira Salles. 

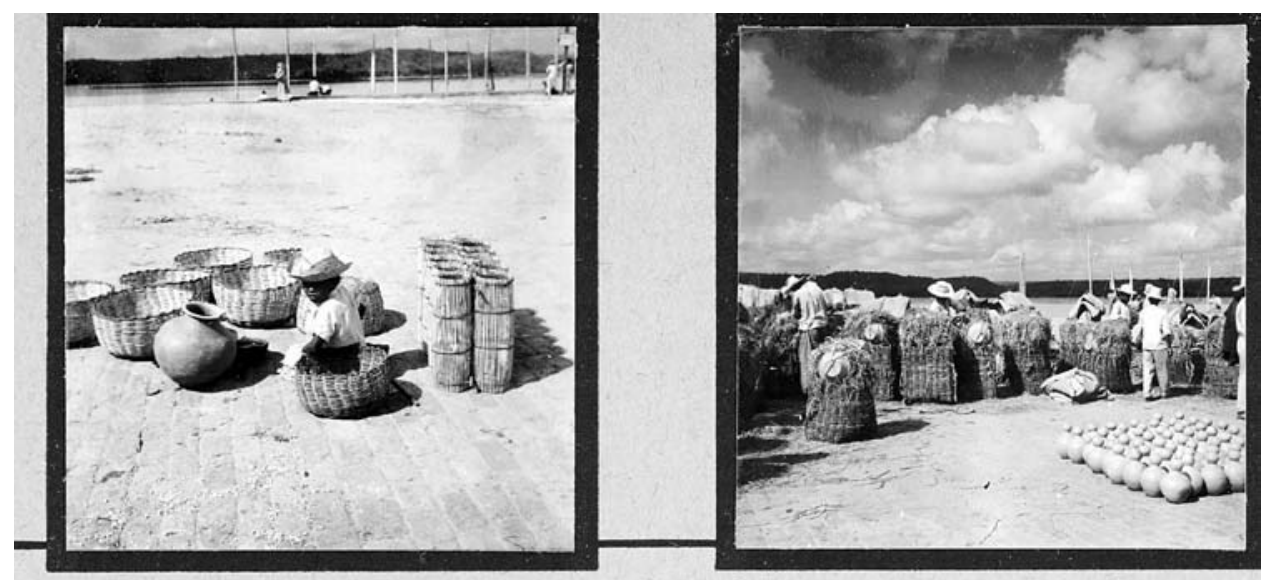

13602

13603

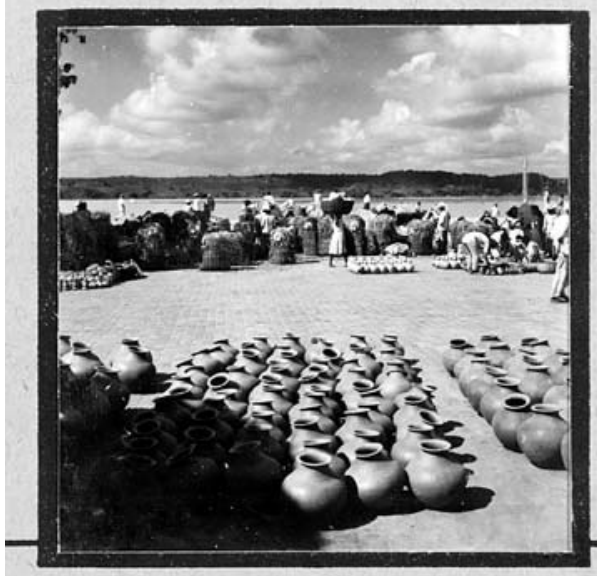

13606
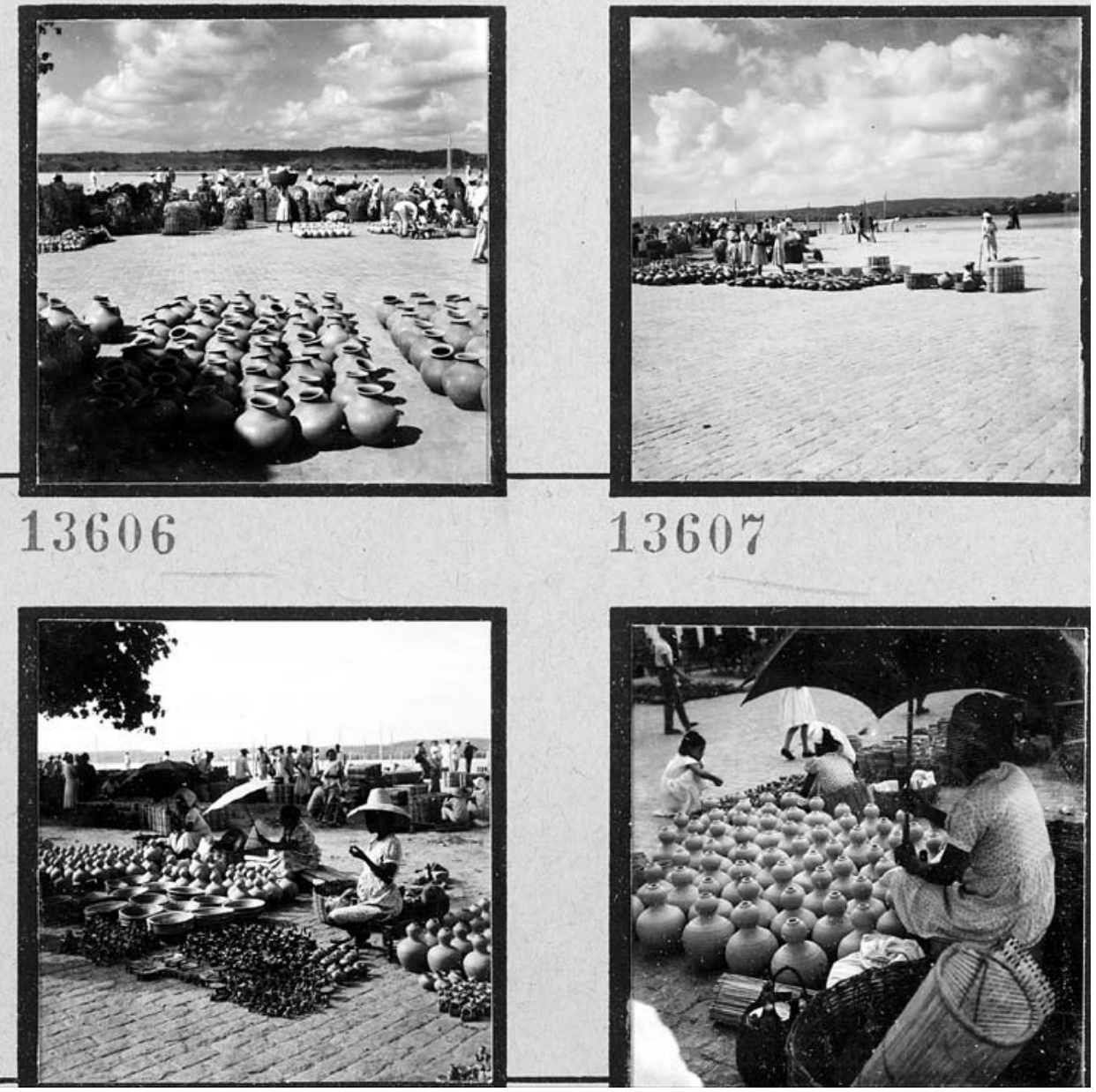

$1360 \%$

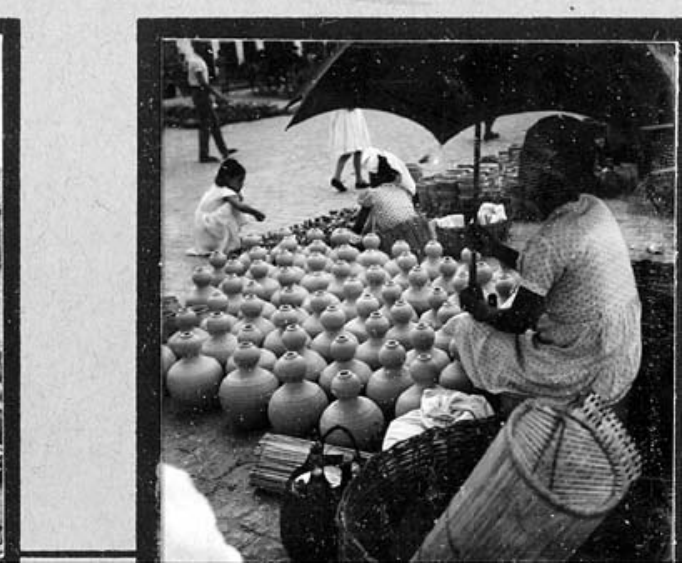




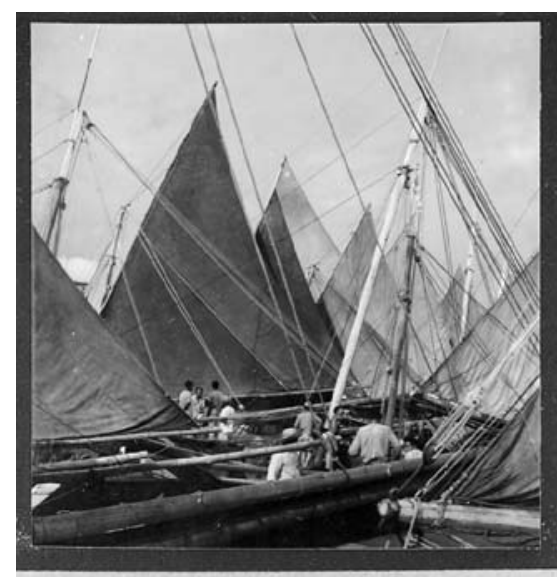

08140

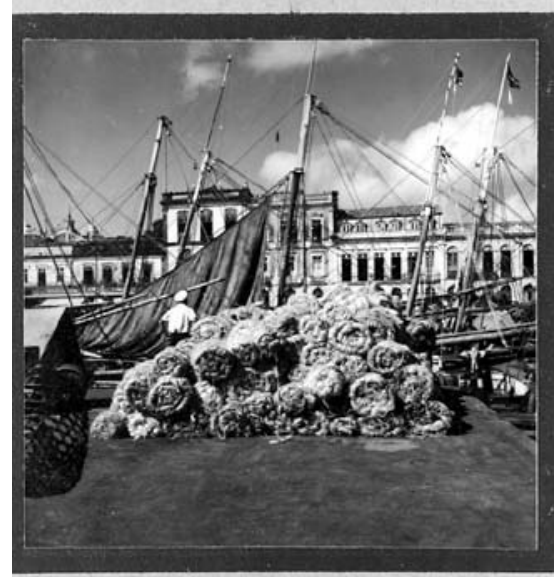

08144

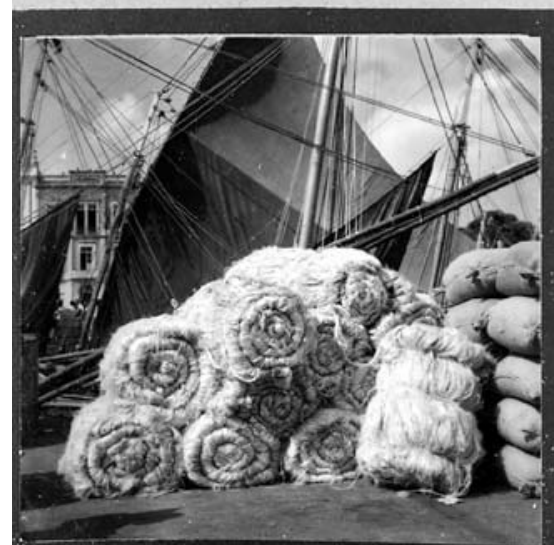

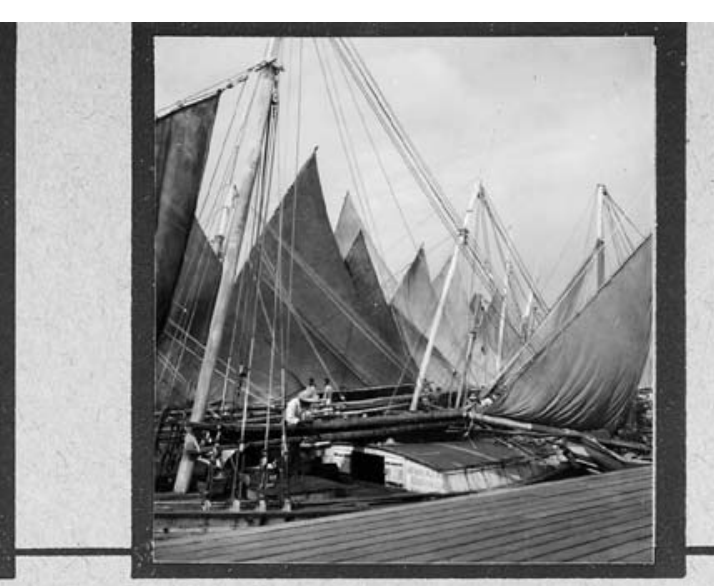

08141

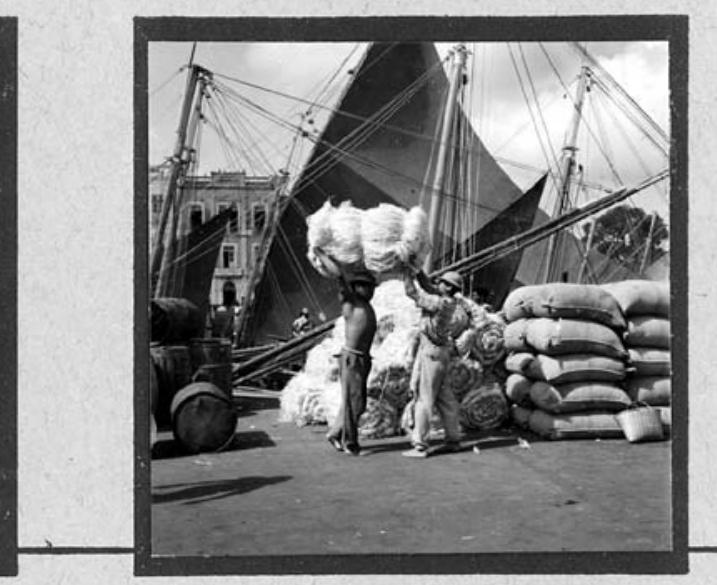

08145

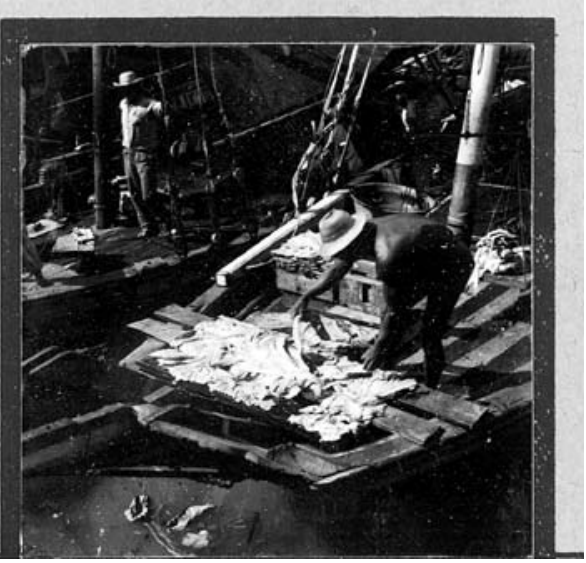

Figura 22 - Mercado Ver-o-Peso, Belém/PA, c. 1954-1957. Fotografias de Marcel Gautherot. Acervo do Instituto Moreira Salles. 

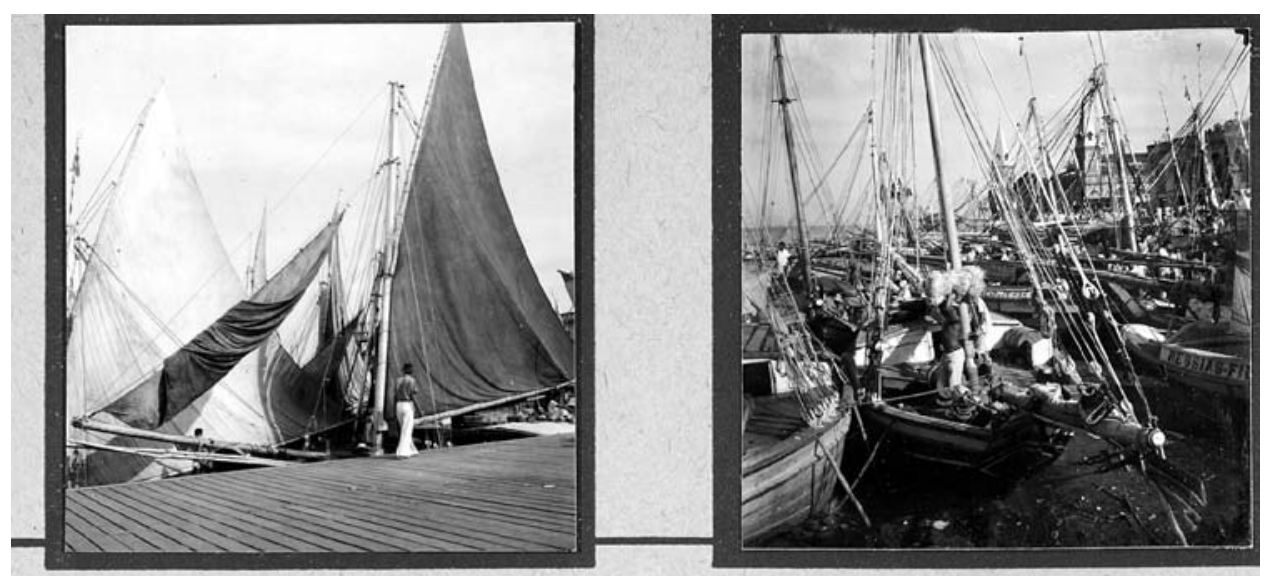

08142

08143

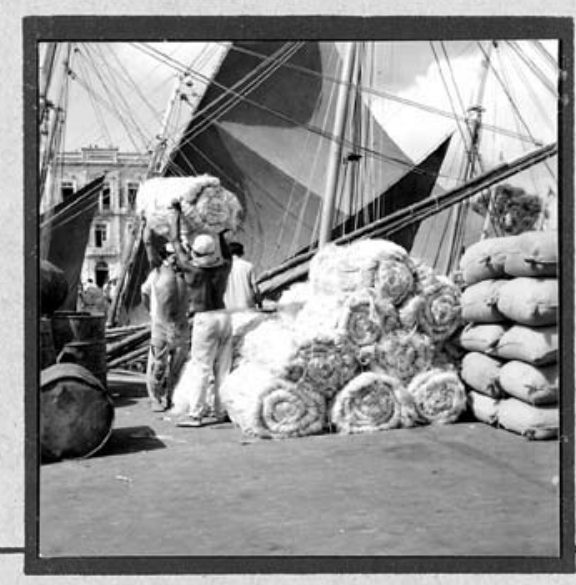

08146

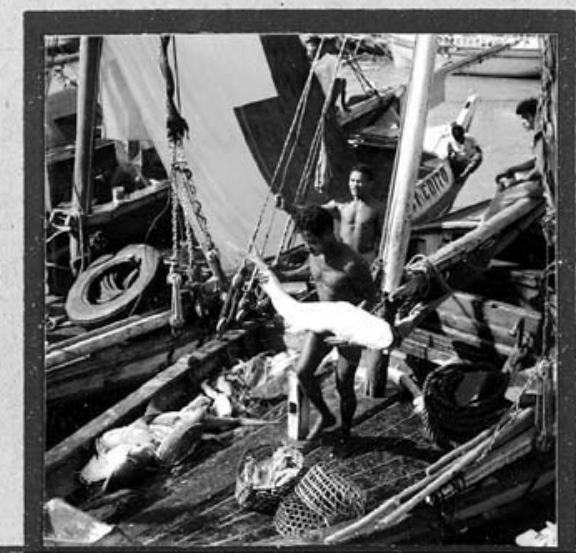

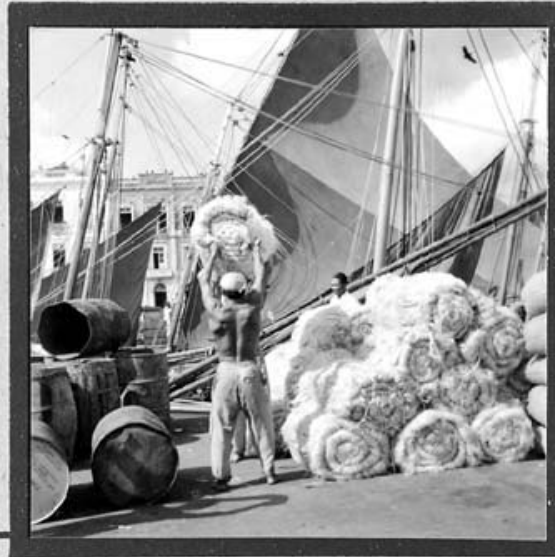

08147

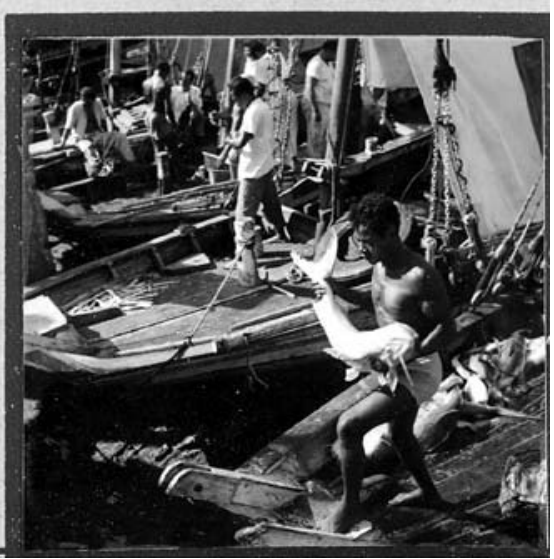



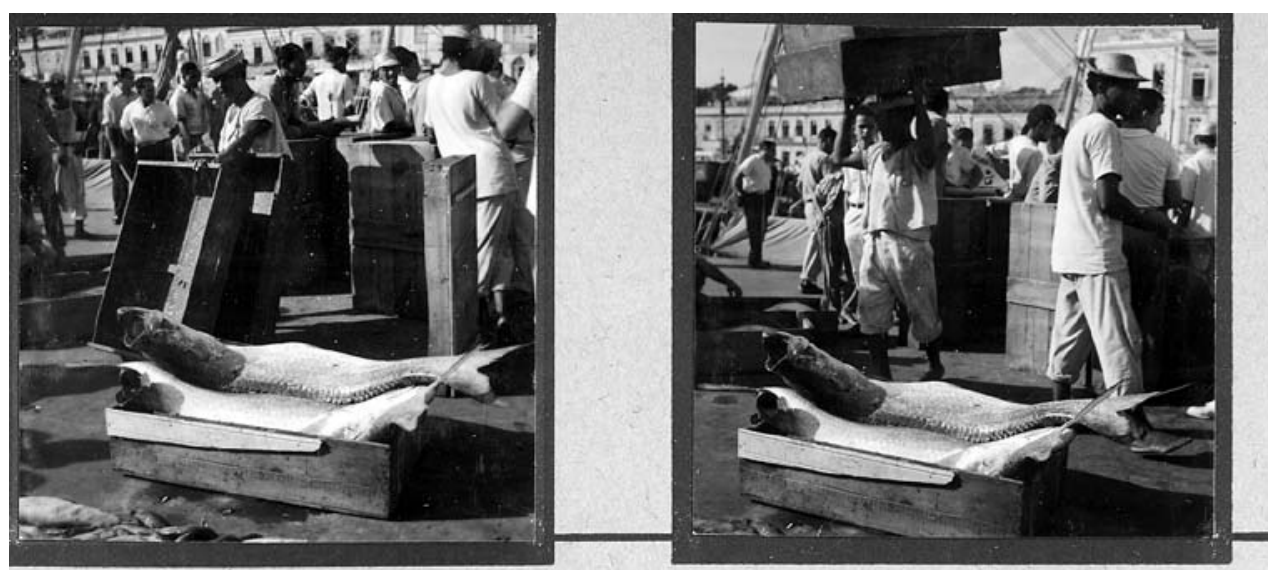

$\longdiv { 8 1 6 4 }$

08165
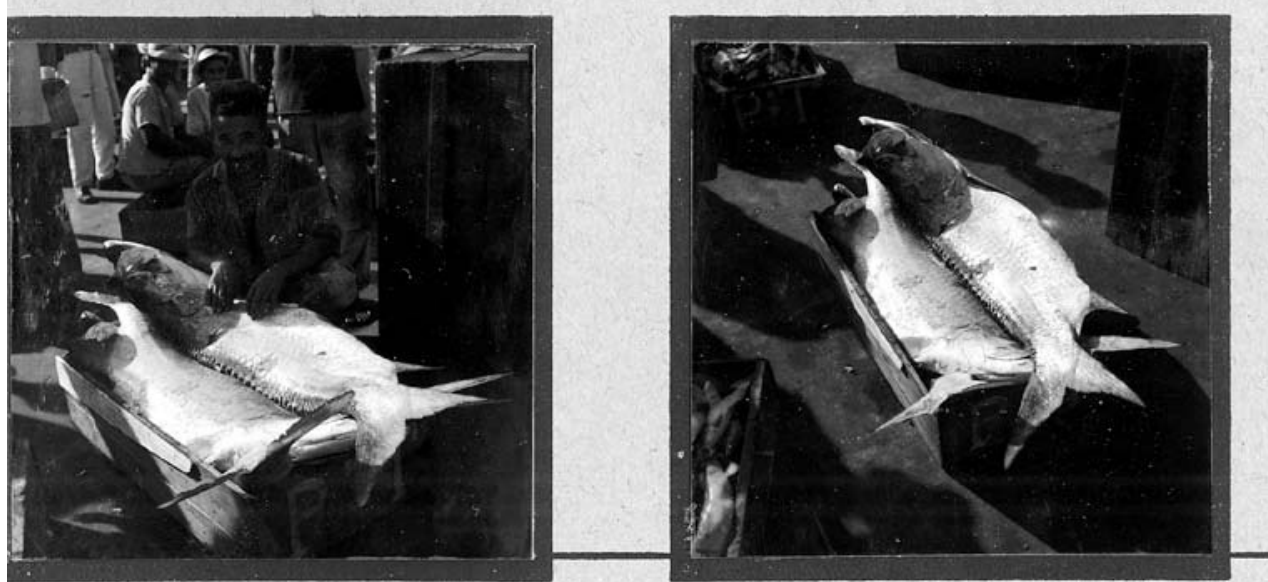

18168
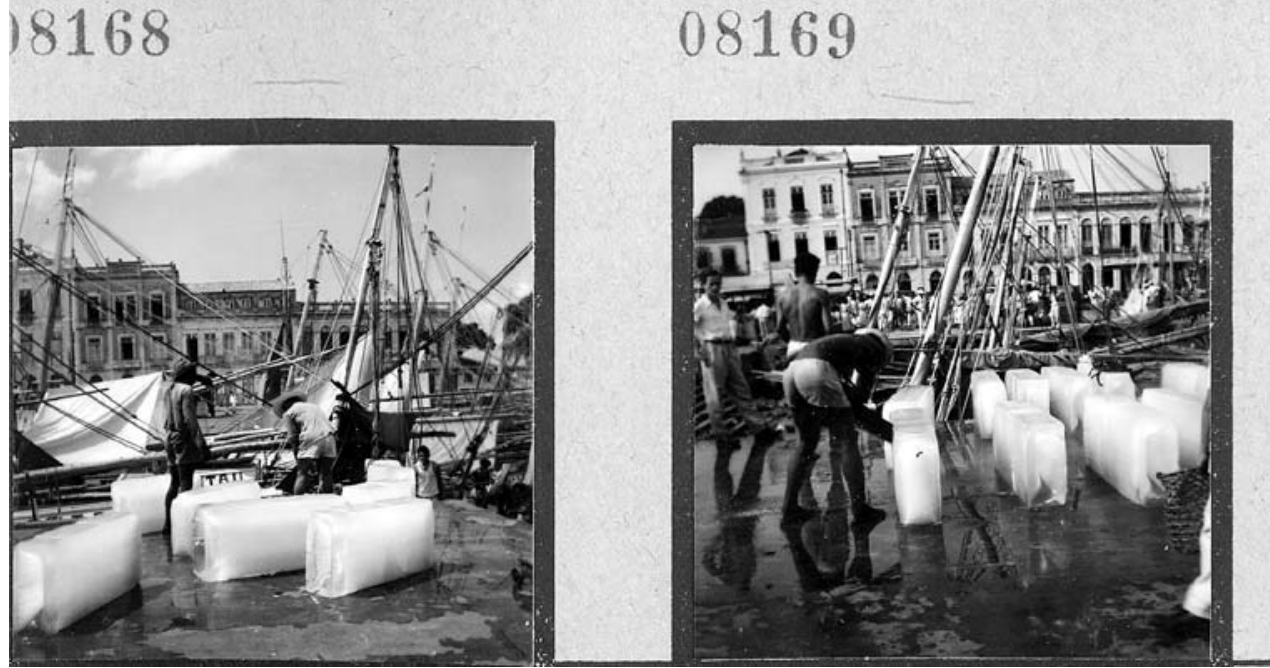

Figura 23 - Mercado Ver-o-Peso, Belém/PA, c. 1954-1957. Fotografias de Marcel Gautherot. Acervo do Instituto Moreira Salles. 

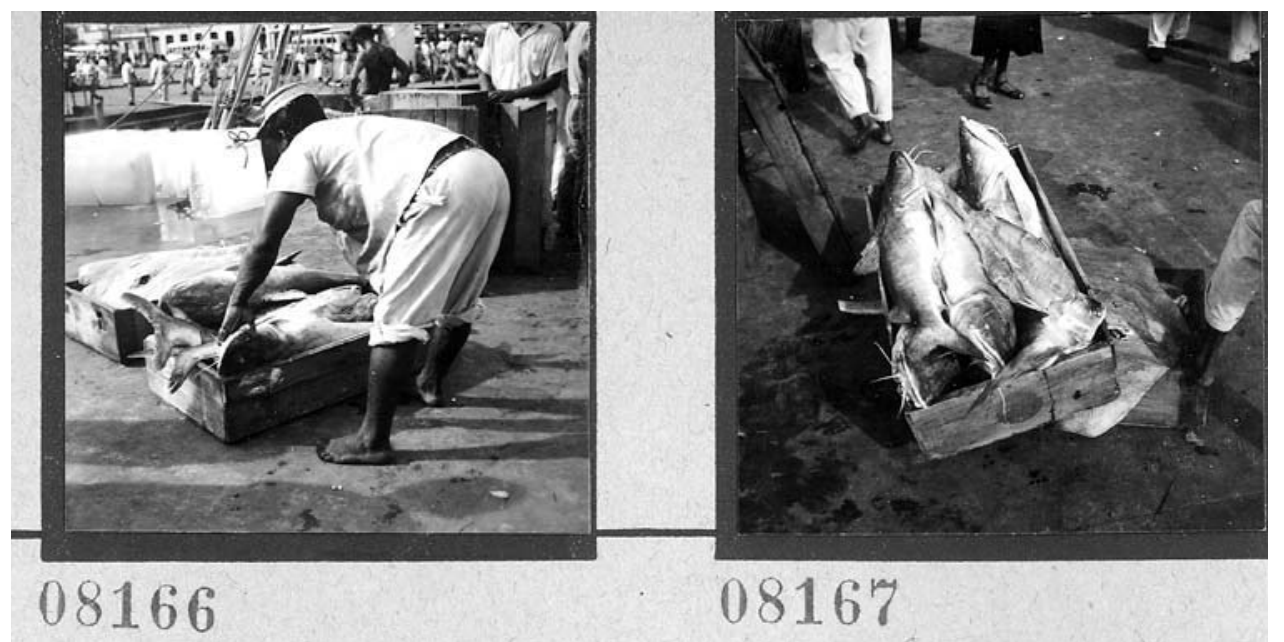

08167
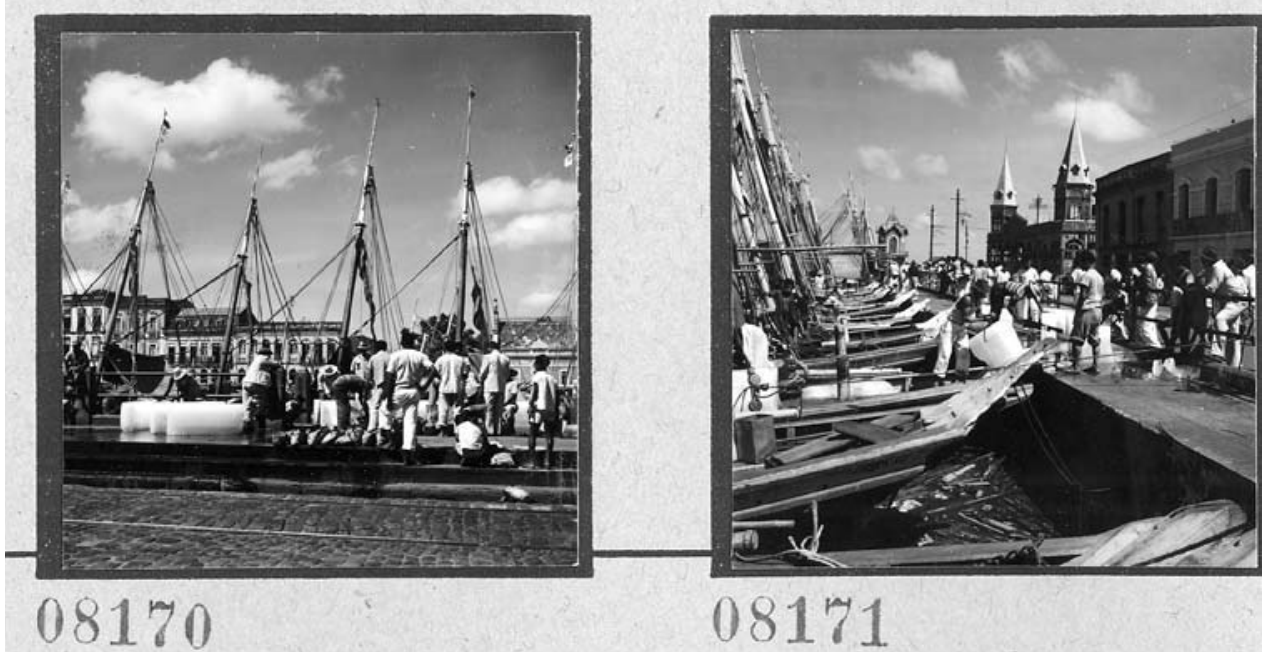

08171
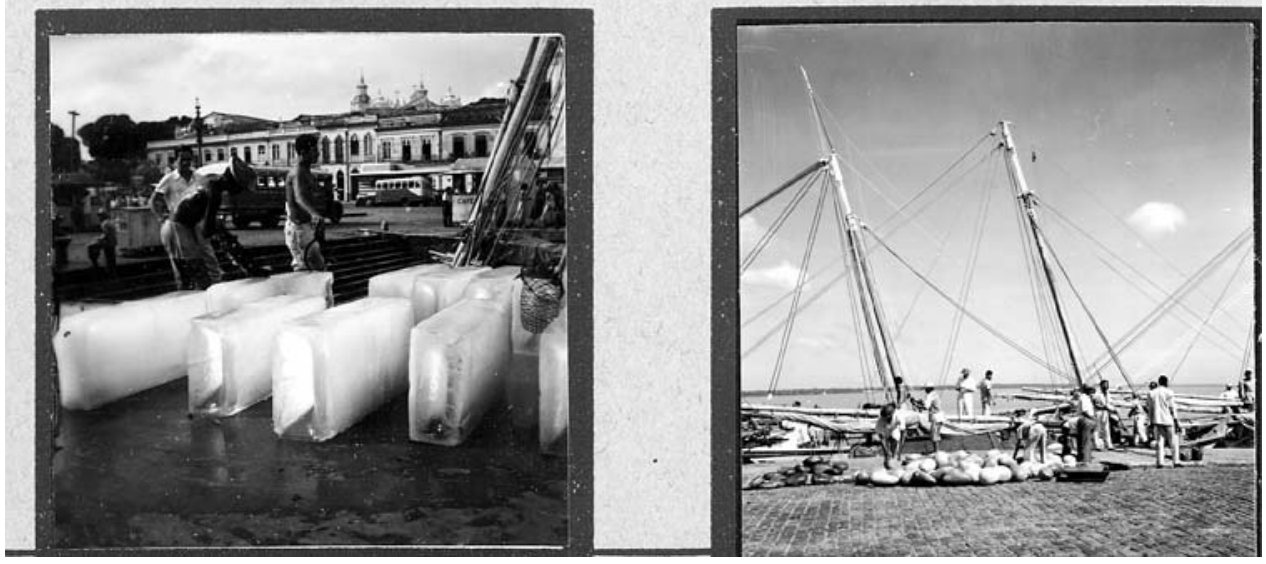

Annals of Museu Paulista.v. 13. n.2. Jul.- Dec. 2005. 


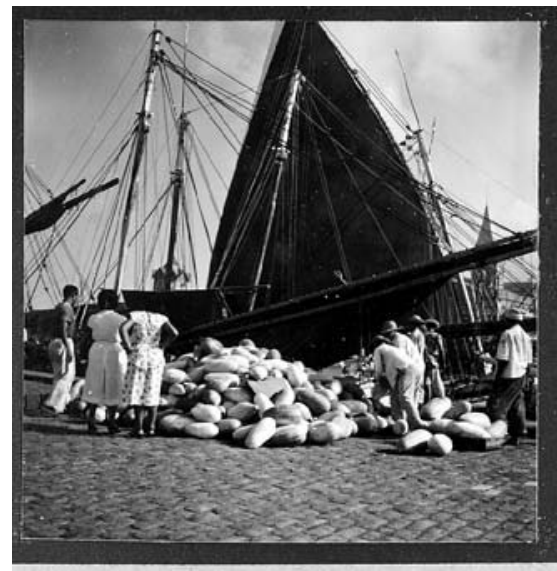

18176

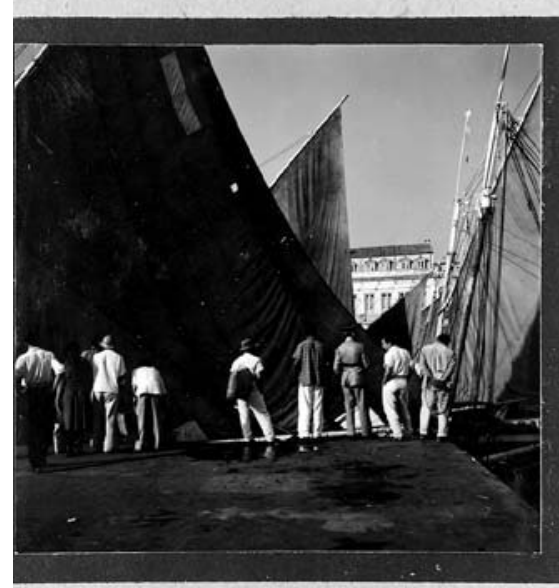

18180

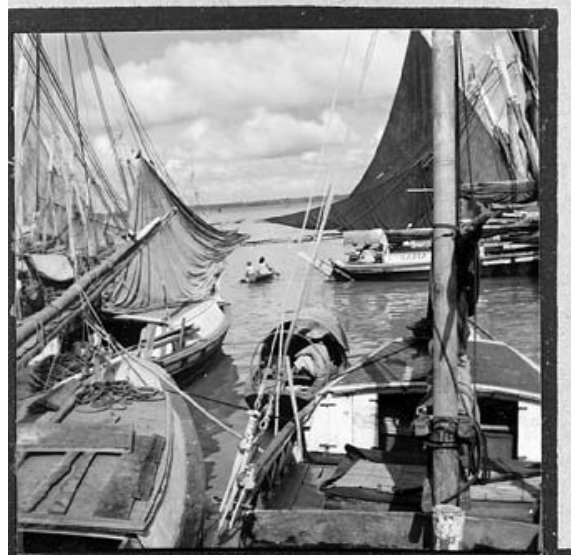

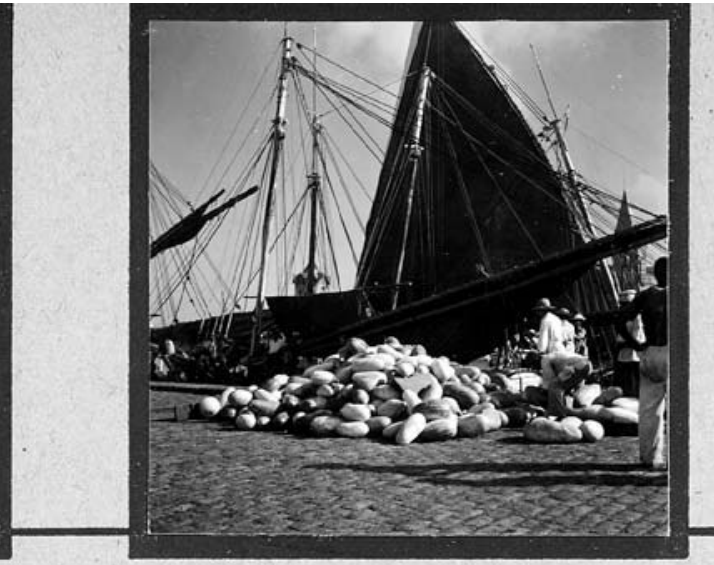

$081 \%$

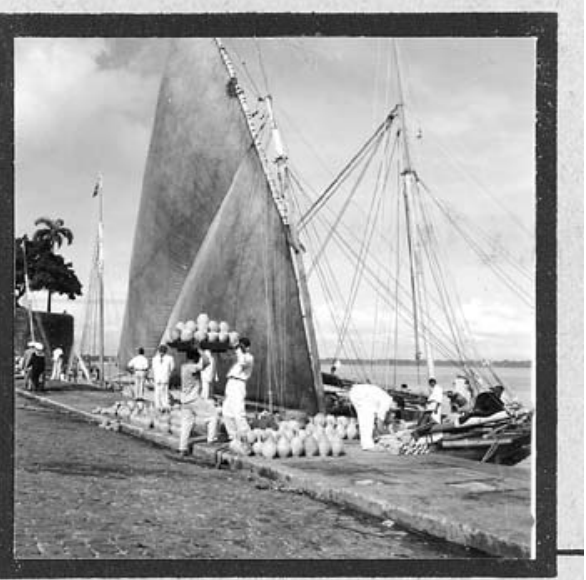

08181

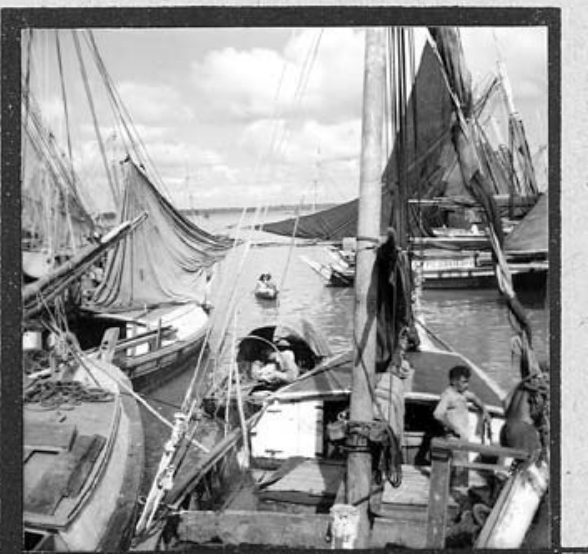

Figura 24 - Mercado Ver-o-Peso, Belém/PA, c. 1954-1957. Fotografias de Marcel Gautherot. Acervo do Instituto Moreira Salles. 


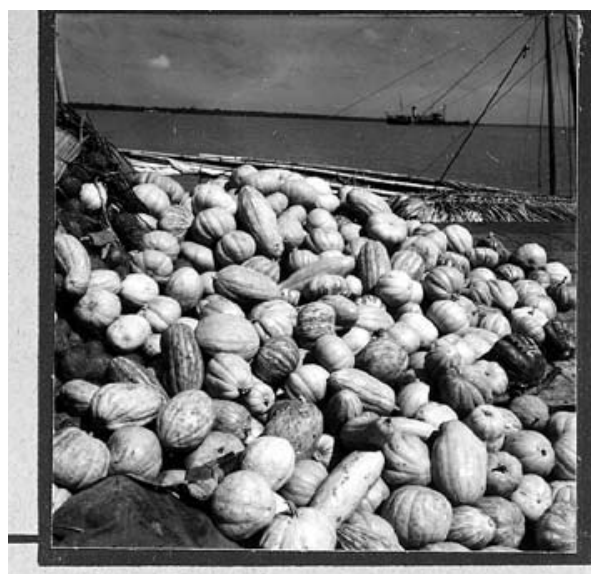

08178

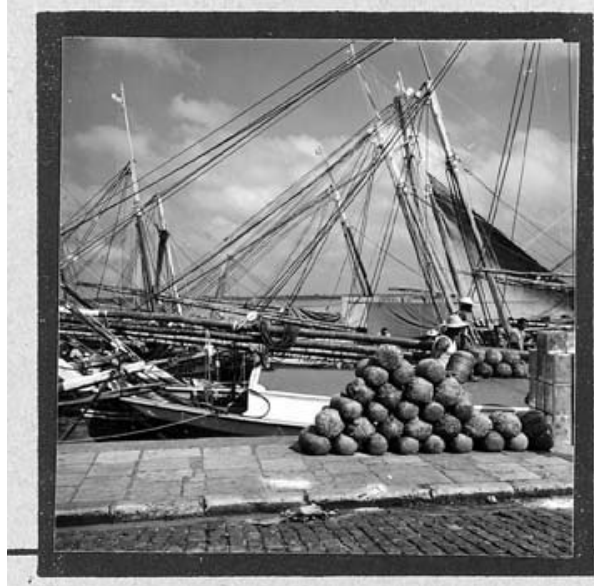

08182

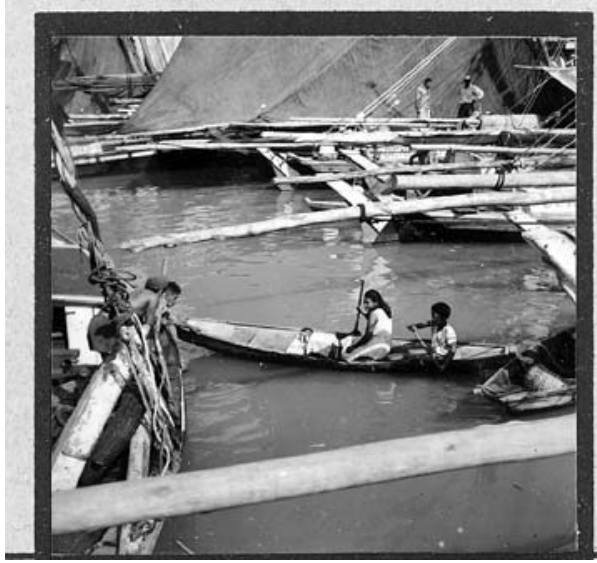

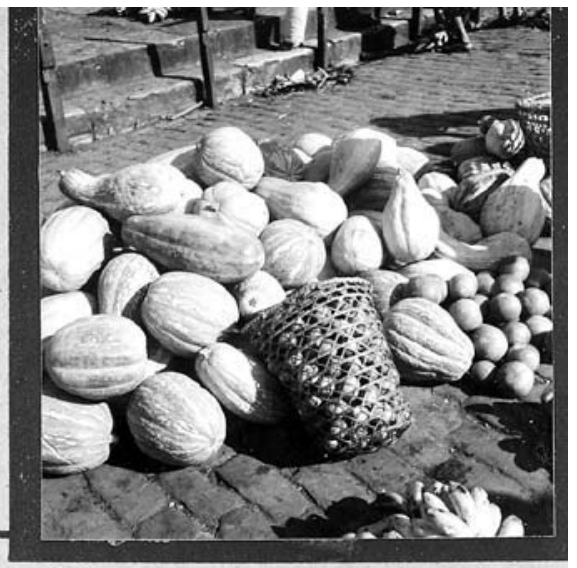

08179

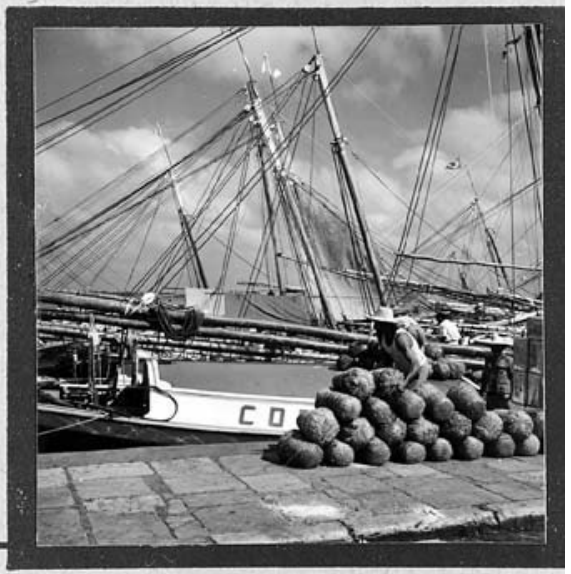

08183

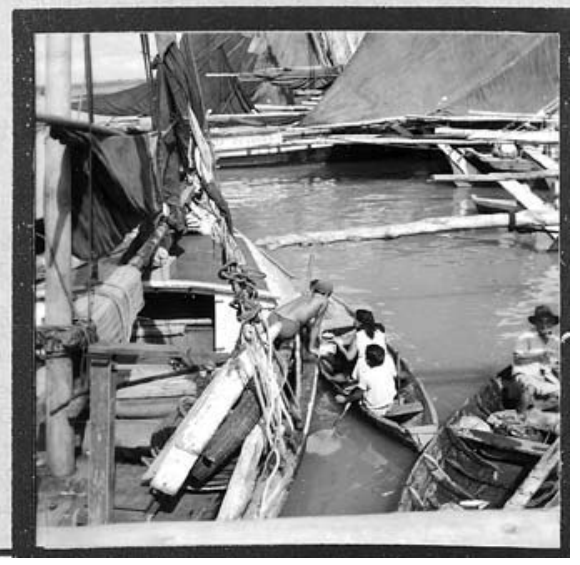




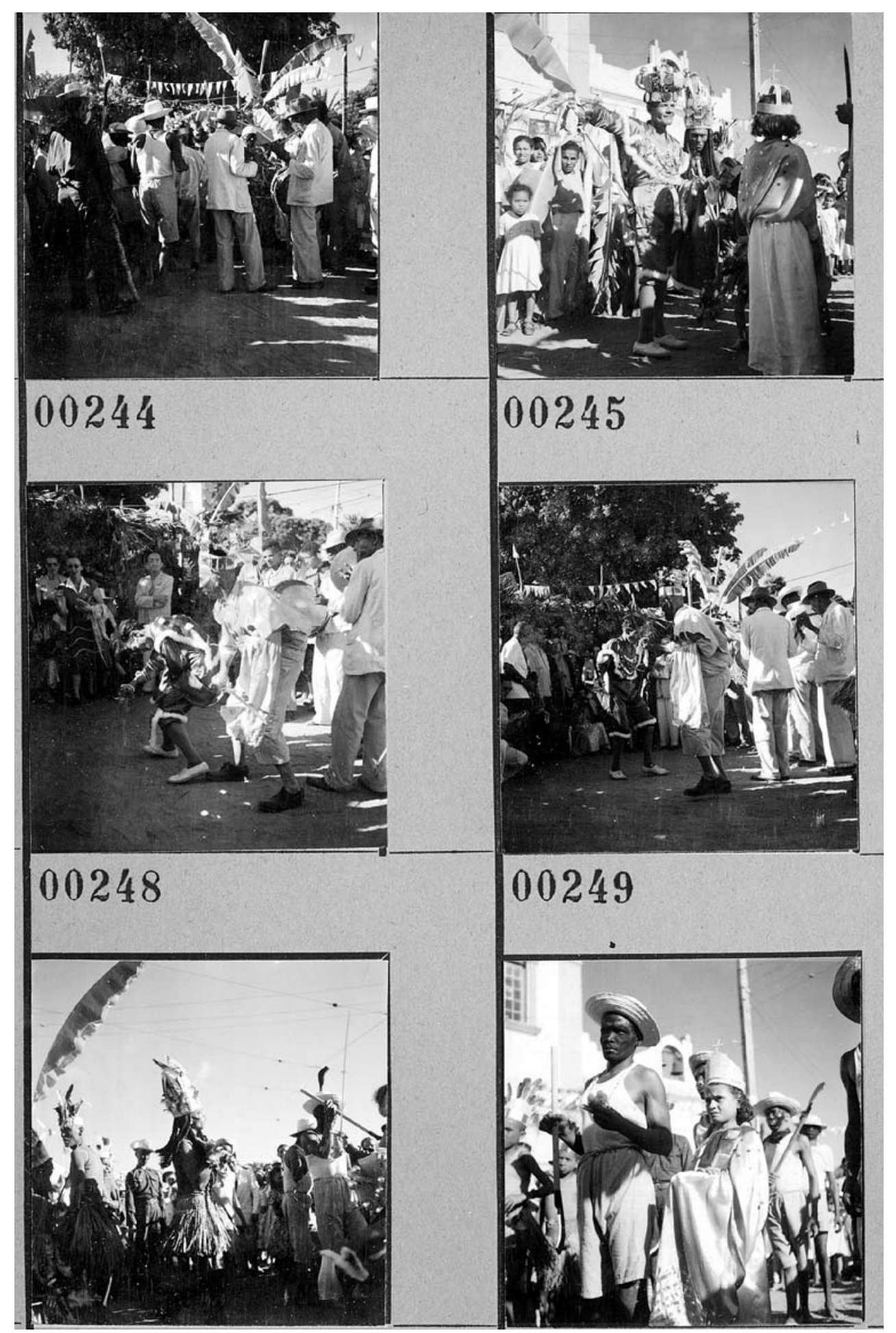

Figura 25 - Quilombo, Maceió/AL, c. 1943. Fotografias de Marcel Gautherot. Acervo do Instituto Moreira Salles. 


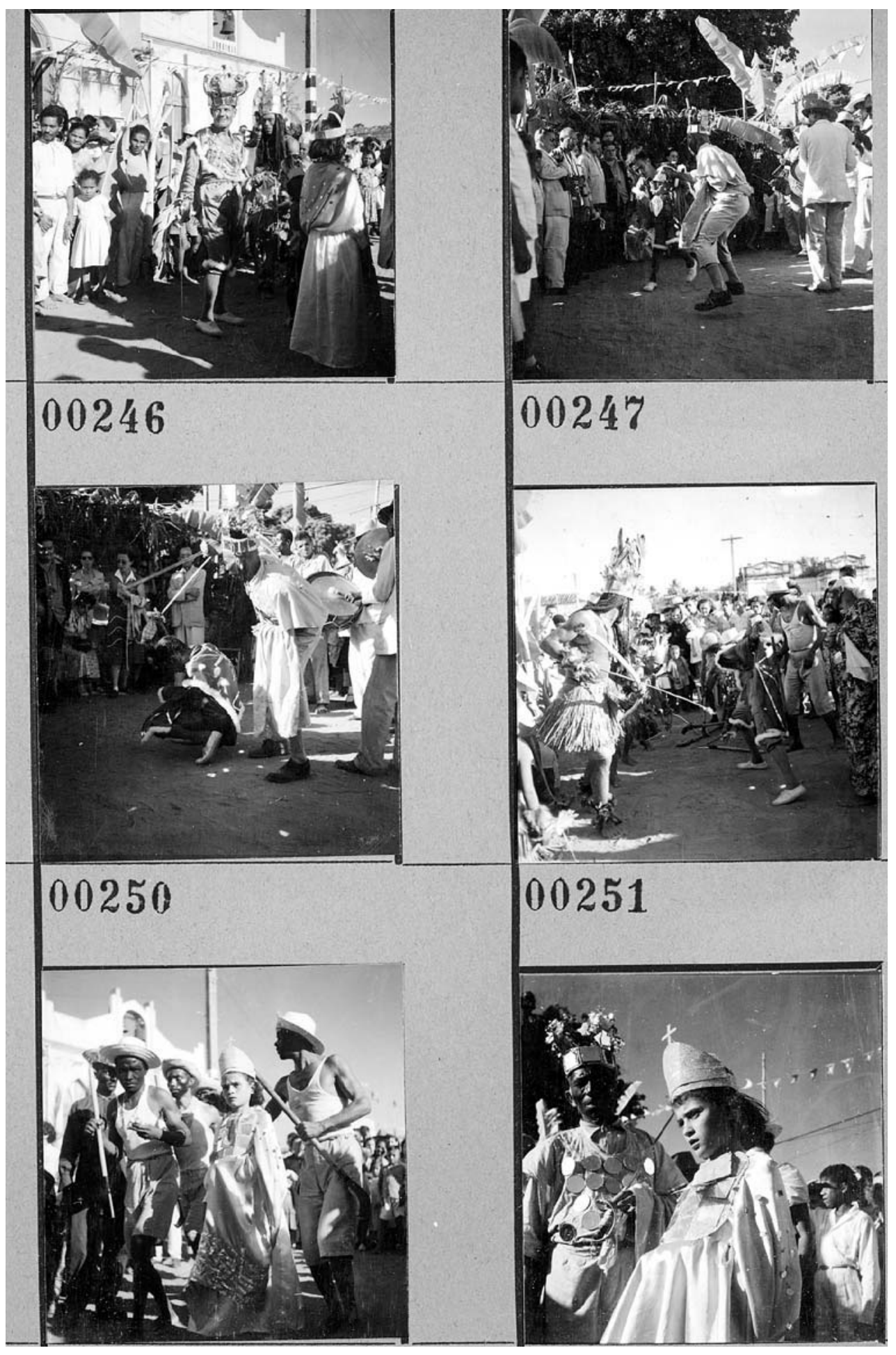




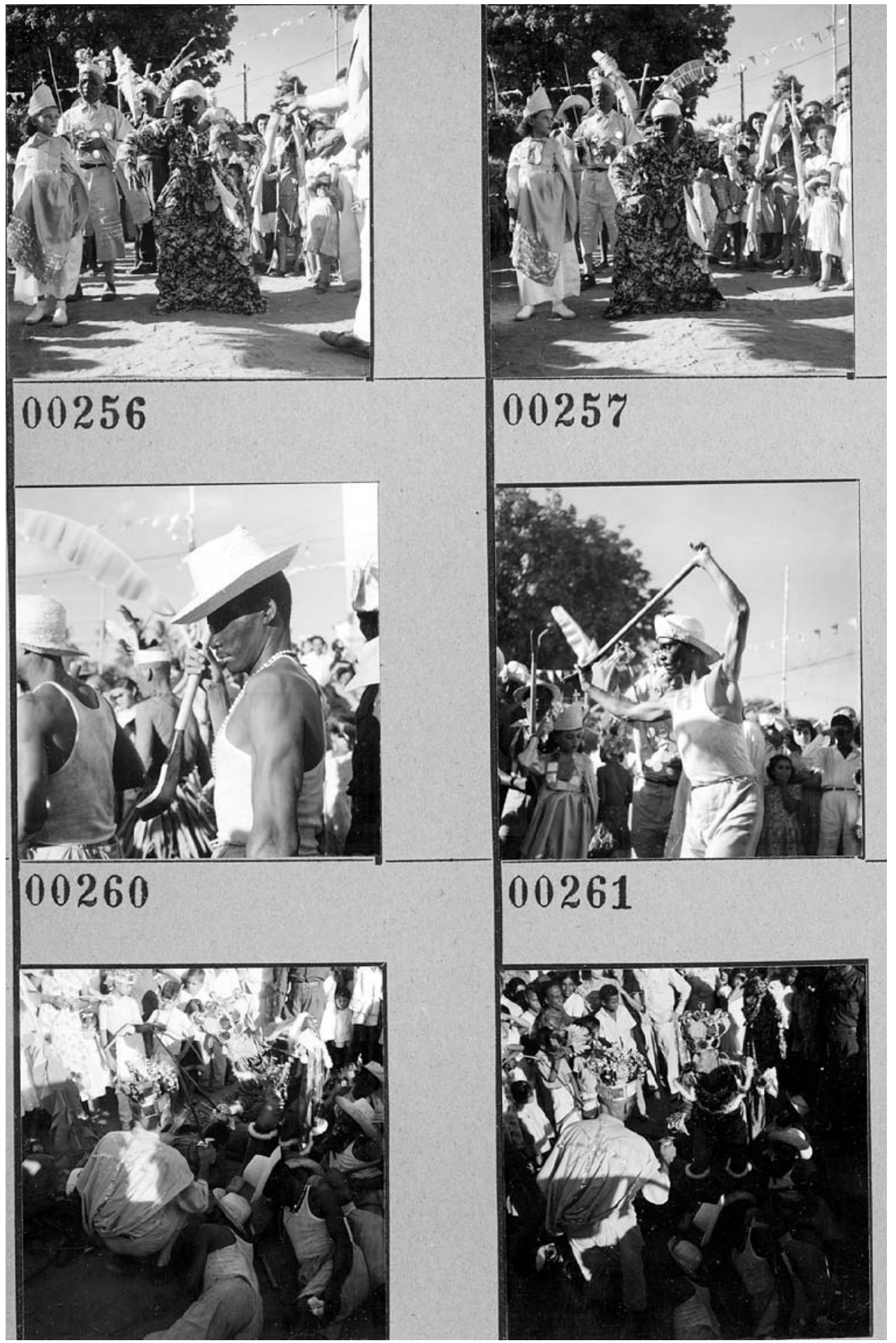

Figura 26 - Quilombo, Maceió/AL, c. 1943. Fotografias de Marcel Gautherot. Acervo do Instituto Moreira Salles. 


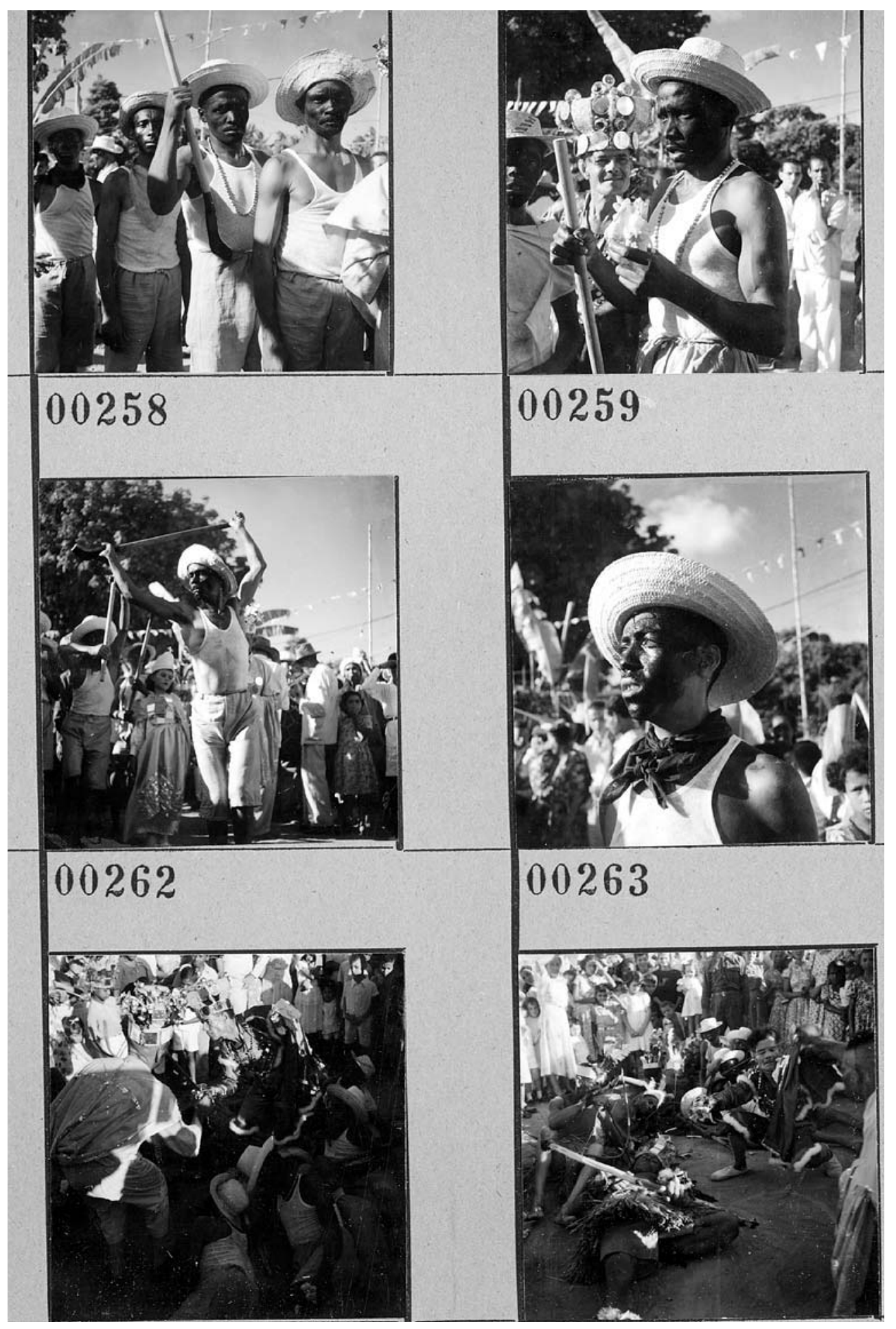




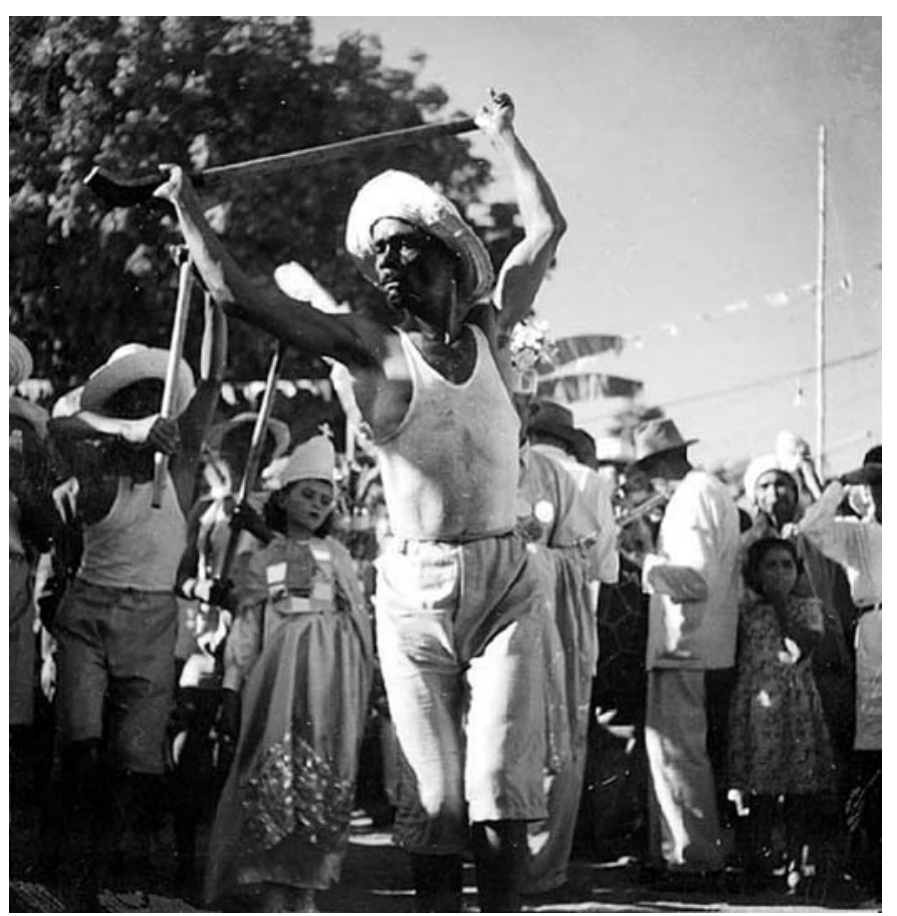

Figura 27 - Quilombo, Maceió/AL, c. 1943. Fotografia de Marcel Gautherot. Acervo do Instituto Moreira Salles.

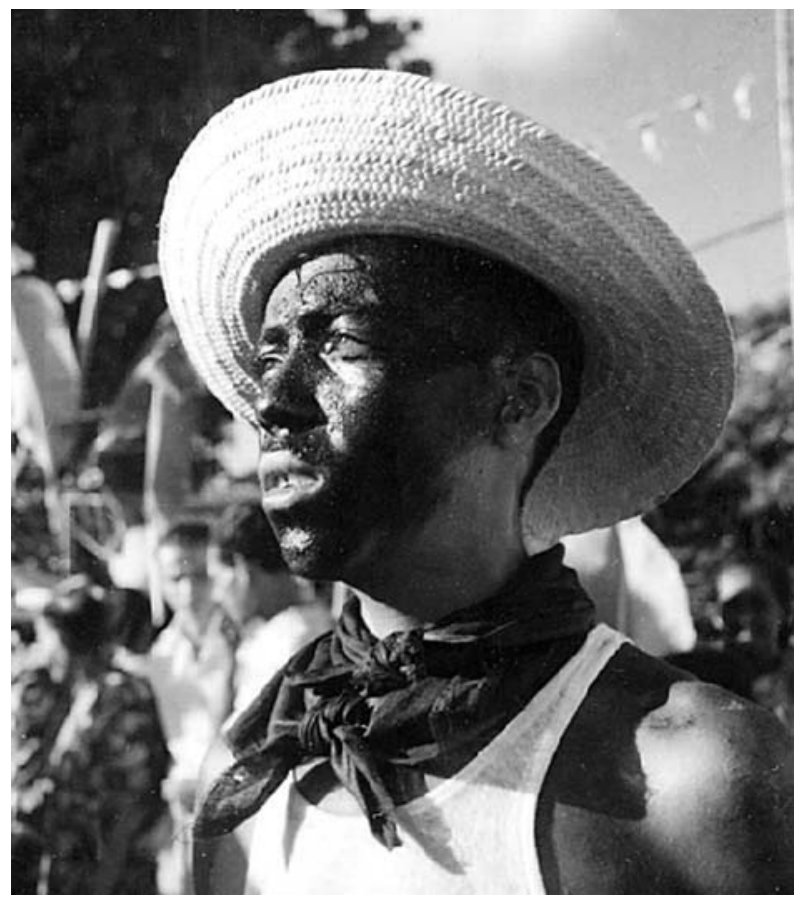

Figura 28 - Quilombo, Maceió/AL, c. 1943. Fotografia de Marcel Gautherot. Acervo do Instituto Moreira Salles. 
desse deslocamento sugerido pelo mercado pressupõe, porém, uma certificação de especialistas e uma definição social da obra de arte ${ }^{106}$.

Nessa perspectiva, a opção do IMS de adquirir a obra completa de fotógrafos envolve um outro tipo de relação e de valor (para além dos valores unitários). $\bigcirc$ cálculo do valor econômico se compõe com contrapartida de investimentos simbólicos associados à preservação e à difusão, ao reconhecimento autorizado e à permanência da obra no tempo.

Após a aquisição da coleção, produz-se, regularmente uma exposição que é uma primeira leitura institucional do acervo. Publicam-se catálogos e livros, avivando-se interesses de estudiosos e colecionadores. Disponibiliza-se a venda de séries contemporâneas de fotografias numeradas, a partir dos originais do acervo. No procedimento de aquisição a fotografia é considerada um bem de uso com restrições de direitos de reprodução. Estimula-se, por um processo de oposição complementar, a singularização da imagem e a comodificação conjunta dos objetos fotográficos.

A dupla imobilização na fotografia e na coleção dos objetos flagrados confere às imagens compiladas, registros reconhecidos do nosso patrimônio cultural material e imaterial, um sentido narrativo particular de produção da nação como "comunidade observada". Instiga, enquanto "sistema de retrospecção" 107 , formas particulares de relações entre o ver, o imaginar e o lembrar o Brasil.

\section{REFERÊNCIAS}

ANDRADE, M. Mário de Andrade: Cartas de trabalbo: correspondência com Rodrigo de Mello Franco de Andrade, 1936-1945. Brasília: Secretaria do Patrimônio Histórico e Artístico Nacional/Fundação Pró-Memória, 1981.

AZEVEDO, J. E. (Org.) Acervo de pesquisas folclóricas de Mário de Andrade: 1935-1938. São Paulo: Centro Cultural São Paulo, 2000.

BARTHE, C. ; PIERRE,A.-L. Photographies et ethnologie: la Photothèque du Musée de l'Homme. Gradhiva, Paris, 25, 1999.

BARTHE, C. De l'échantillon au corpus, du type à la personne.Journal des Anthropologues, Paris, n. 80-81, p. 71-90, 2000.

BAZIN,A. Qu'est-ce que le cinéma? Paris: Ed. du Cerf, 1987.

BECKER, H. Photography and Sociology. In: BECKER, H. Doing things together: selected papers. Evaston: Northwestern University Press. 1986.

BELTING, H. Le lieu des images: un essai anthropologique. In:BELTING, H. Pour une anthropologie des images. Paris: Gallimard, 2004. 
BONTE, P.; IZAR, M. Dicitonnaire de l'ethnologie et de l'anthropologie. Paris: Quadrige/Presses Universitaires de France, 1991.

CANDIDO, A. A personagem do romance. In: CANDIDO, A. et al. A personagem de ficção. São Paulo: Perspectiva, 2004.

CARNEIRO, E. Bumba-meu-boi é teatro de pobre. Correio da Manhã. Rio de Janeiro, 6-12 de novembro de 1950 (suplemento Singra 46).

Pesquisa de Folclore (1955). In: CARNEIRO, E. Dinâmica do folclore. Rio de Janeiro: Civilização Brasileira, 1965.

CLIFFORD, J. Colecionando arte e cultura. Revista do Patrimônio Histórico e Artístico Nacional, Brasília, n. 23, 1994.

A experiência etnográfica: antropologia e literatura no século $X X$. Rio de Janeiro: Editora da UFRJ, 1998.

COGEZ, G. Les écrivains voyageurs au XXe siècle. Paris: Éditions du Seuil, 2004.

COLLEYN, J-P. L'Ethnographie, essais d'écriture. Critique, Paris, t. LX, n. 680-681, jan-fev., 2004.

COSTA, L. Prefácio. In: ANDRADE, R.M.F. de. Rodrigo e seus tempos. Rio de Janeiro: Fundação Pró-Memória, 1986.

DIAS, N. Le Musée d'Ethnographie du Trocadéro (1878-1908): anthropologie et muséologie en France. Paris: Éditions du CNRS, 1991.

EDUARDS, E. Anthropology and photography 1860-1920. London:The Royal Anthropological Institute/Yale University Press, 1992.

Photographic types: the pursuit of method. Visual anthropology. n. 3 (2-3), 1990.

FONSECA, M. C. L. O patrimônio em processo: trajetória da política federal de preservação no Brasil, $2^{\mathrm{a}}$ ed. Rio de Janeiro: Editora da UFRJ/Minc/IPHAN, 2005.

FROTA,L.C. Introdução. In: BAHIA, Rio São Francisco, Recôncavo e Salvador: fotografias de Marcel Gautherot. Rio de Janeiro: Nova Fronteira, 1995.

GORGUS, N. Le magicien des vitrines: le muséologue Georges-Henri Rivière. Paris: Éditions de la Maison des Sciences de l'Homme, 2003.

LEIRIS, M. L'Afrique fantôme. Paris: Gallimard, 1934.

L'ESTOILE, B. Ciência do homem e 'dominação racional': saber etnológico e política indígena na África colonial francesa. In: L'ESTOILE, B.; NEIBURG, F; SIGAUD, L. Antropologia, impérios e estados nacionais. Rio de Janeiro: Relume Dumará: Faperj, 2002.

LÉVI-STRAUSS, C. Tristes tropiques. Paris: Librairie Plon, 1955. 
LUGON, O. Le style documentaire d'Auguste Sander à Walker Evans, 1920 - 1945. Paris: Macula, 2001.

MARESCA, S. Sortir des impasses du vintage. La recherche photographique. n. 18, 1995.

La photographie: un miroir des sciences sociales. Paris: L'Harmattan, 1996.

MARIO de Andrade e a sociedade de etnografia e folclore, no Departamento de Cultura da Prefeitura do Município de São Paulo, 1936-1939. Rio de Janeiro: Funarte/INF, São Paulo: Secretaria Municipal de Cultura, 1983.

MAUSS, M. Manuel d'ethnographie. Paris: Petite Bibliothèque Payot, 1967.

MÉTRAUX.A. American Anthropologist, Washington, v. 66, n.3, part 1, 1964.

MÉTRAUX, A.; VERGER, P. Le pied à l'étrier, correspondance 1946-1963. Paris: Jean-Michel Place, 1994.

MICELI, S. Intelectuais à brasileira. São Paulo: Companhia das Letras, 2001.

(Org.). História das Ciências Sociais no Brasil. São Paulo: Sumaré, 2001.

MINISTÉRIO DA CULTURA/IPHAN/Arquivo Noronha Santos. Fundo IPHAN, série:Arquivo Técnico e Administrativo do IPHAN; subsérie: Representante; período 1945-1956; caixa 351; pasta 130 (Correspondência/recibos Marcel Gautherot).

MOULIN, R. La genèse de la rareté artistique. Ethnologie Française, Paris, n. 2-3, p. 241-258, 1978.

NOBRE, A.L. A eficácia do corte. In: O BRASIL de Marcel Gautberot. Rio de Janeiro: Instituto Moreira Salles, 2001.

PIETTE,A. Ethnographie de l'action: L'observation des détails. Paris: Éditions Métailié, 1996.

POMIAN, K. Entre l'invisible et le visible: la collection. In: POMIAN. K. Collectionneurs, amateurs et curieux : Paris-Venise XVI-XVIIIe. siècles. Paris: Gallimard, 1987.

Coleção. In: Enciclopédia Einaudi. Lisboa: Imprensa Nacional/Casa da Moeda, 1984. (Memória-História, v.1).

Collection et musées (note critique). Annales ESC, Paris, n. 6, 1993.

PONTES, H. Retratos do Brasil: editores, editoras e 'coleções brasiliana' nas décadas de 30, 40 e 50. In: MICELI, S. (Org.). História das ciências sociais no Brasil. São Paulo: Sumaré, 2001.

PRICE, S; JAMIN, J. Entretien avec Michel Leiris. Gradhiva, Paris, n. 4, 1988.

VERGER, P. 50 Anos de fotografia. Salvador: Corrupio, 1982.

ROUILLÉ,A.Vertige du nombre. La Recherche Photographique, Paris, n. 10, 1991. 
ROUILLÉ, A. La photographie. Paris: Gallimard, 2005.

SEGALA, L. Bumba-meu-boi Brasil. In: O BRASIL de Marcel Gautherot. São Paulo: Instituto Moreira Salles, 2001.

SIMMEL, G. O Estrangeiro. In: MORAES FILHO, E. (Org.). Georg Simmel: Sociologia. São Paulo: Ática, 1983.

THIESSE,A-M. La création des identités nationales: Europe XVIIIe - XXe siècle. Paris: Éditons du Seuil, 1999.

TURAZZI, M. I. Uma cultura fotográfica. Revista do Patrimônio Histórico e Artístico Nacional, Brasília, n. 27, 1998.

VELOSO, M. O tecido do tempo: a idéia de patrimônio cultural no Brasil (1920-1970). 1992. 498f. Tese (Doutorado) - Departamento de Antropologia, Universidade de Brasília, 1992.

VILHENA, L.R. Projeto e missão: o movimento folclórico brasileiro 1947-1964. Rio de Janeiro: FGV/Funarte, 1997.

WRIGHT,T. Photography: theories of realism and convention. In: EDUARDS, E. (Ed.). Anthropology and Photography. London:The Royal Anthropological Institute/Yale University Press, 1992.

Artigo apresentado em 10/2005. Aprovado em 10/2005. 